\title{
Rehabilitation of the South Jetty, Ocean City, Maryland
}

\author{
by Gregory P. Bass \\ U.S. Army Engineer District, Baltimore \\ Edward T. Fulford \\ Andrews, Miller, \& Assoc., Inc. \\ Steven G. Underwood, Larry E. Parson \\ Coastal Engineering Research Center
}

Approved For Public Release; Distribution Is Unlimited

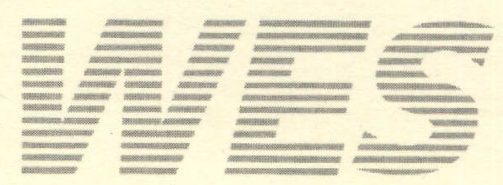


The contents of this report are not to be used for advertising, publication, or promotional purposes. Citation of trade names does not constitute an official endorsement or approval of the use of such commercial products. 


\section{Rehabilitation of the South Jetty, Ocean City, Maryland}

by Gregory P. Bass

U.S. Army Engineer District, Baltimore

P.O. Box 1715

Baltimore, MD 212030-1715

Edward T. Fulford

Andrews, Miller, \& Assoc., Inc.

508 Maryland Avenue

Cambridge, MD 21613

Steven G. Underwood, Larry E. Parson

Coastal Engineering Research Center

U.S. Army Corps of Engineers

Waterways Experiment Station

3909 Halls Ferry Road

Vicksburg, MS 39180-6199

Final report

Approved for public release; distribution is unlimited

Prepared for U.S. Army Corps of Engineers

Washington, DC 20314-1000 


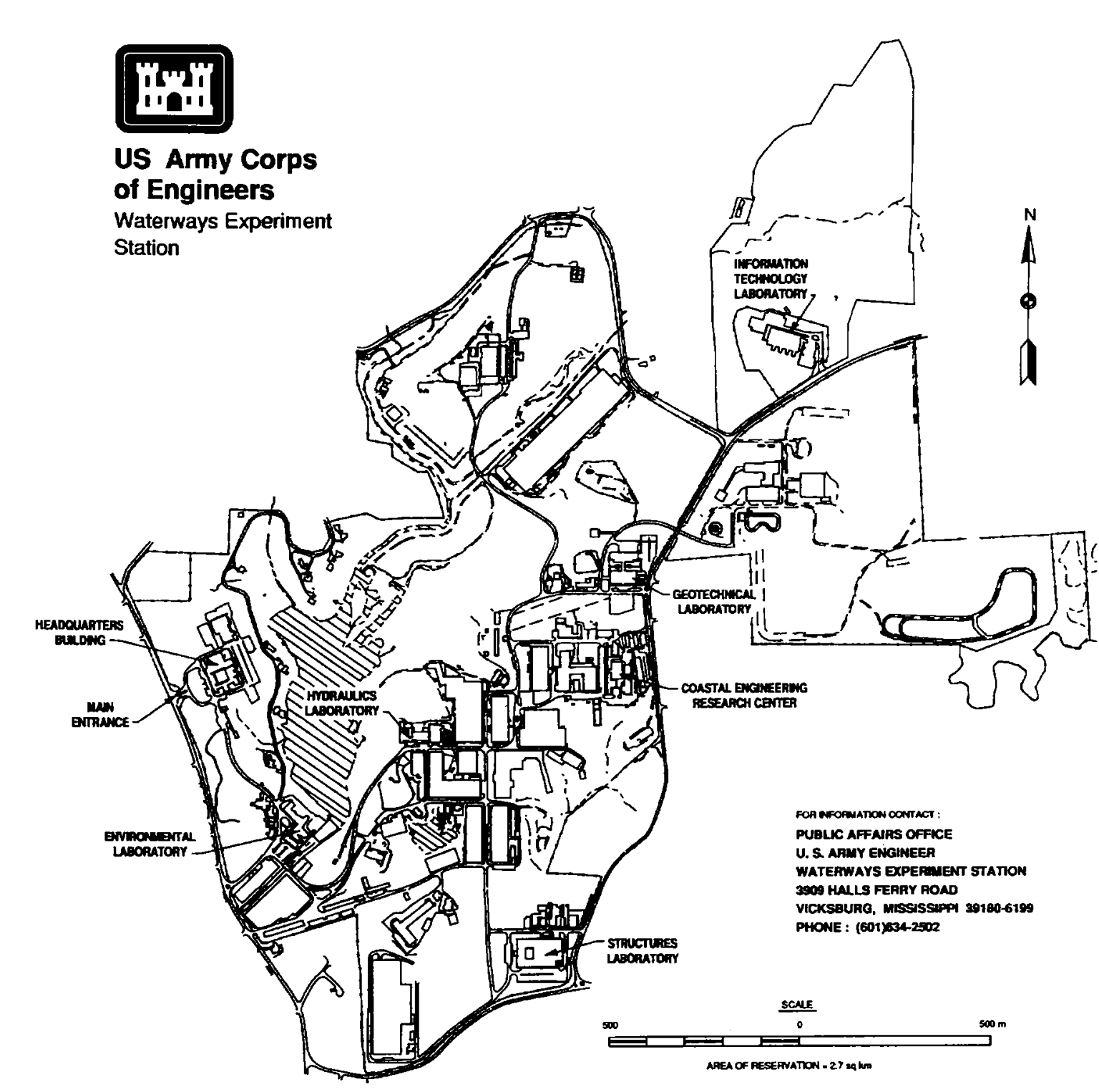

Waterways Experiment Station Cataloging-in-Publication Data

Rehabilitation of the south jetty, Ocean City, Maryland / by Gregory P.

Bass ... [et al.] ; prepared for U.S. Army Corps of Engineers.

122 p. : ill. ; $28 \mathrm{~cm}$. -- (Technical report ; CERC-94-6)

Includes bibliographical references.

1. Jetties -- Maintenance and repair. 2. Shore protection -- Maryland

-- Ocean City. 3. Coastal engineering -- Maryland -- Ocean City.

4. Breakwaters -- Maintenance and repair. I. Bass, Gregory P.

II. United States. Army. Corps of Engineers. III. Coastal Engineering

Research Center (U.S.) IV. U.S. Army Engineer Waterways Experiment

Station. V. Series: Technical report (U.S. Army Engineer Waterways

Experiment Station) ; CERC-94-6.

TA7 W34 no.CERC-94-6 


\section{Contents}

Preface $\ldots \ldots \ldots \ldots \ldots \ldots \ldots \ldots \ldots$ vi

Conversion Factors, Non-SI to SI Units of Measurement . . . . . . vii

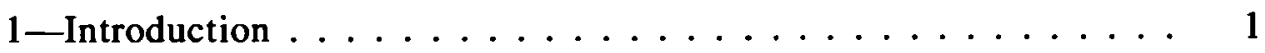

Project History . . . . . . . . . . . . . . 1

Project Features $\ldots \ldots \ldots \ldots \ldots \ldots \ldots$

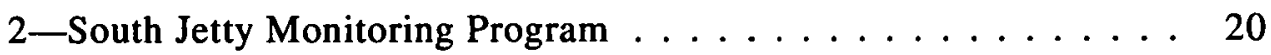

Monitoring Completed Coastal Projects (MCCP) Program . . . . 20

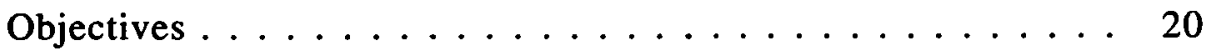

Data Collection .................. 21

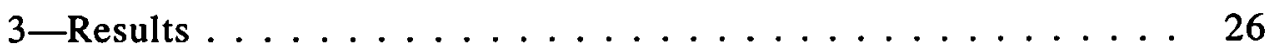

Shoreline Change Maps . . . . . . . . . . . . . 26

Conclusions Relating to the Cause of the Problem Shoal . . . . . 27

Effectiveness of the Rehabilitated Cross Section as a Littoral

Barrier . . . . . . . . . . . . . . . . . 29

Effectiveness of the Shoreline Stabilization on the Northern

Shoreline of Assateague Island . . . . . . . . . . 32

Consideration of the Shore Protection Manual Longshore

Transport Formula . . . . . . . . . . . . . . 42

Distribution of Longshore Sand Transport Across the Surf Zone . 42

Shoreline and Profile Response/Onshore-Offshore Sand

Transport . . . . . . . . . . . . . . . 48

Ebb Shoal Equilibrium and Northern Assateague Island Growth . 52

Scour Hole Stabilization . . . . . . . . . . . . . 55

$4-$ Conclusions $\ldots \ldots \ldots \ldots \ldots \ldots \ldots \ldots \ldots \ldots$

References . . . . . . . . . . . . . . . . . . 59

Appendix A: Waverider Wave Buoy Data . . . . . . . . A 1

Appendix B: PUV Wave and Current Gauge Data . . . . . . . B 1

Appendix C: Profile Comparisons . . . . . . . . . . C1 
Appendix D: Shoreline Change Maps ............ D

SF 298

\section{List of Figures}

Figure 1. Area map showing the location of the project site .... 2

Figure 2. Condition of Ocean City Inlet on 18 September 1933 after its creation by a severe hurricane on 25 August $1933 \ldots 3$

Figure 3. Location of the south jetty constructed in $1934 \ldots 4$

Figure 4. Condition of the inlet, 9 October $1934 \ldots \ldots 6$

Figure 5. Condition of the inlet, 15 January $1935 \ldots 7$

Figure 6. Condition of the inlet, 6 December $1935 \ldots . \ldots 8$

Figure 7. Condition of the inlet, 6 May 1962 showing erosion caused by a northeaster on 15 March $1962 \ldots \ldots 9$

Figure 8. Schematic of the tidal currents and the sand transportation patterns inside the inlet ............. 10

Figure 9. Plan view of the reconstructed south jetty . . . . . . 13

Figure 10. Profile of the reconstructed south jetty . . . . . . . . 14

Figure 11. Typical cross-section of the reconstructed south jetty . . 15

Figure 12. Cross-section of the filling in on the scour hole and placement of pound stone $\ldots \ldots \ldots 17$

Figure 13. Plan view of the three breakwaters constructed to protect the northern end of Assateague Island . . . . . . 18

Figure 14. Typical cross-section of the breakwaters . . . . . . . 19

Figure 15. Location of data collection instruments used in study . . 22

Figure 16. Location of the 19 profile sites monitored . . . . . . . 23

Figure 17. Condition of inlet on 29 August 1986 after the jetty reconstruction .................. 28

Figure 18. Location of the inlet on 23 December 1987 showing no indication of the reoccurrence of the shoal . . . . . 29

Figure 19. Condition of inlet on 9 April 1989 showing continued erosion of the northwest shoreline . . . . . . 30

Figure 20. Condition of inlet on 21 February 1990 showing continued erosion of the northwest shoreline . . . . . . . . 31 
Figure 21. Evolution of the crenulate bays between the breakwater segments ...................... 33

Figure 22. Sand accretion and the associated increase in elevation south of the jetty at sta $2+00 \ldots \ldots 34$

Figure 23. Cross-section of sand accretion and the associated increase in elevation immediately south of the jetty at sta $6+00 \ldots 35$

Figure 24. Cross-section of sand accretion and the associated increase in elevation immediately south of the jetty at sta $8+00 \ldots 36$

Figure 25. Photographs showing wind-blown sand deposited on top of the south jetty .............. 37

Figure 26. Results from physical model developed by Silvester and Ho (1972) ................... 39

Figure 27. Relationship between $a$ and $b$ for various angles of wave obliquity ....................... 39

Figure 28. Migration of shoreline segments between breakwaters . . 41

Figure 29. Grid pattern developed for analysis of the profile data for the south jetty ................. 45

Figure 30. Incremental cell volumes indicating net longshore

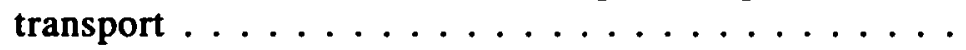

Figure 31. Variation in beach profile coefficient $A$ along the coast of northern Assateague Island: depth 0 to $-15 \mathrm{ft}$ NGVD . . . 51

Figure 32. Variation in beach profile coefficient $A$ along the coast of northern Assateague Island: depth 0 to $-25 \mathrm{ft} \mathrm{NGVD} \mathrm{.} 51$

Figure 33. Cumulative volume for the ebb-tidal delta from 1937 through $1990 \ldots \ldots \ldots \ldots \ldots$

Figure 34. Ebb delta growth rate per year, 1937 to 1967 vs. 1967 to $1990 \ldots \ldots \ldots \ldots \ldots \ldots \ldots$

Figure 35. Ebb delta growth rate since $1967 \ldots \ldots \ldots 54$

Figure 36. Historical shoreline erosion rate for northern Assateague Island ............... 55

Figure 37. Scour hole contours indicating no erosion from 1984 to $1990 \ldots \ldots \ldots \ldots$. . . . . . . . . . . 56

Figure 38. Cumulative shoal volume vs. change in Assateague Island's northern shoreline erosion rates $\ldots \ldots \ldots . \ldots 58$ 


\section{Preface}

The investigation summarized in this report was conducted by the U.S. Army Engineer Waterways Experiment Station's (WES's) Coastal Engineering Research Center (CERC) and was selected for study and funded by the Monitoring Completed Coastal Projects (MCCP) program. The MCCP Program Manager was Ms. Carolyn Holmes. This program was sponsored by Headquarters, U.S. Army Corps of Engineers (HQUSACE). The HQUSACE Technical Monitors were Messrs. John H. Lockhart, Jr., John G. Housley, and Barry W. Holliday. The project was under the jurisdiction of the U.S. Army Engineer District, Baltimore (NAB).

Work was performed under the general supervision of Ms. Joan Pope, Chief, Coastal Structures and Evaluation Branch; Mr. Thomas W. Richardson, Chief, Engineering Development Division; Mr. Charles C. Calhoun, Jr., Assistant Director; and Dr. James R. Houston, Director, CERC.

This report was prepared by Messrs. Gregory P. Bass, NAB; Edward T. Fulford, Andrews, Miller, \& Assoc., Inc., formerly of NAB; and Steven G. Underwood, Louisiana Department of Natural Resources, Coastal Restoration Division, formerly of CERC, and Larry E. Parson, CERC. Field data collection was performed by many individuals of NAB and CERC. Technical assistance in preparing manuscripts, figures, and general support coordination was provided by Messrs. Darryl Bishop and Corey Kindhart and Ms. Leona Patty. Technical reviewers of the report were Dr. Donald K. Stauble, Dr. Yen-Hsi Chu, and Mr. Larry E. Parson, CERC.

At the time of publication of this report, Director of WES was Dr. Robert W. Whalin. Commander was COL Bruce K. Howard, EN. 


\section{Conversion Factors, Non-SI to SI Units of Measurement}

Non-SI units of measurement used in this report can be converted to SI units as follows:

\begin{tabular}{|l|l|l|}
\hline Multiply & By & To Obtain \\
\hline cubic yards & 0.7645549 & cubic meters \\
\hline feet & 0.3048 & meters \\
\hline inches & 2.54 & centimeters \\
\hline miles (U.S. statute) & 1.609347 & kilometers \\
\hline square feet & 0.09290304 & square meters \\
\hline square miles & 2.589998 & square kilometers \\
\hline tons (2,000 pounds, mass) & 907.1847 & kilograms \\
\hline
\end{tabular}





\section{Introduction}

\section{Project History}

Ocean City, Maryland, located on Fenwick Island, is part of the central Delaware-Maryland-Virginia (Delmarva) barrier island chain (Figure 1). Ocean City is situated about 35 miles $^{1}$ south of the entrance to Delaware Bay and about 105 miles north of the Virginia Capes. To the south of Ocean City, across Ocean City Inlet, is Assateague Island, which is a barrier island between Sinepuxent Bay and the Atlantic Ocean. Sinepuxent Bay extends from Isle of Wight Bay to the north to Chincoteague Bay to the south.

Historically, storms have opened temporary inlets from the ocean to Sinepuxent Bay. A severe hurricane on 25 August 1933 opened an inlet at the south end of the Ocean City boardwalk. Figure 2 shows the condition of the inlet as it existed 18 September 1933. Prior to the inlet breaching, Congress had authorized an inlet to be constructed approximately 5 miles south of the new inlet to serve commercial navigation interests in the area. After reviewing the situation in 1933, Congress authorized stabilization of the natural inlet.

The north jetty was constructed in 1934 to an elevation of $+2.7 \mathrm{ft} \mathrm{Na-}$ tional Geodetic Vertical Datum (NGVD) (Figure 3). Within 3 years, the fillet on the north side of the jetty had reached the top of the jetty and sand was being deposited into the inlet. In order to prevent sediment overtopping, a concrete superstructure was constructed to an elevation of $+10.7 \mathrm{ft}$ NGVD beginning at the boardwalk and extending $100 \mathrm{ft}$ seaward, at which point the crest elevation decreased to $+7.7 \mathrm{ft}$ NGVD for $254 \mathrm{ft}$, and then decreased to $+5.7 \mathrm{ft}$ NGVD for the remainder of its length. In 1956, the north jetty was rehabilitated by raising the section at $+5.7 \mathrm{ft}$ NGVD to $+7.7 \mathrm{ft}$ NGVD, making it an integral part of the new jetty section.

1 A table of factors for converting non-SI units of measurement to SI units is presented on page vii. 


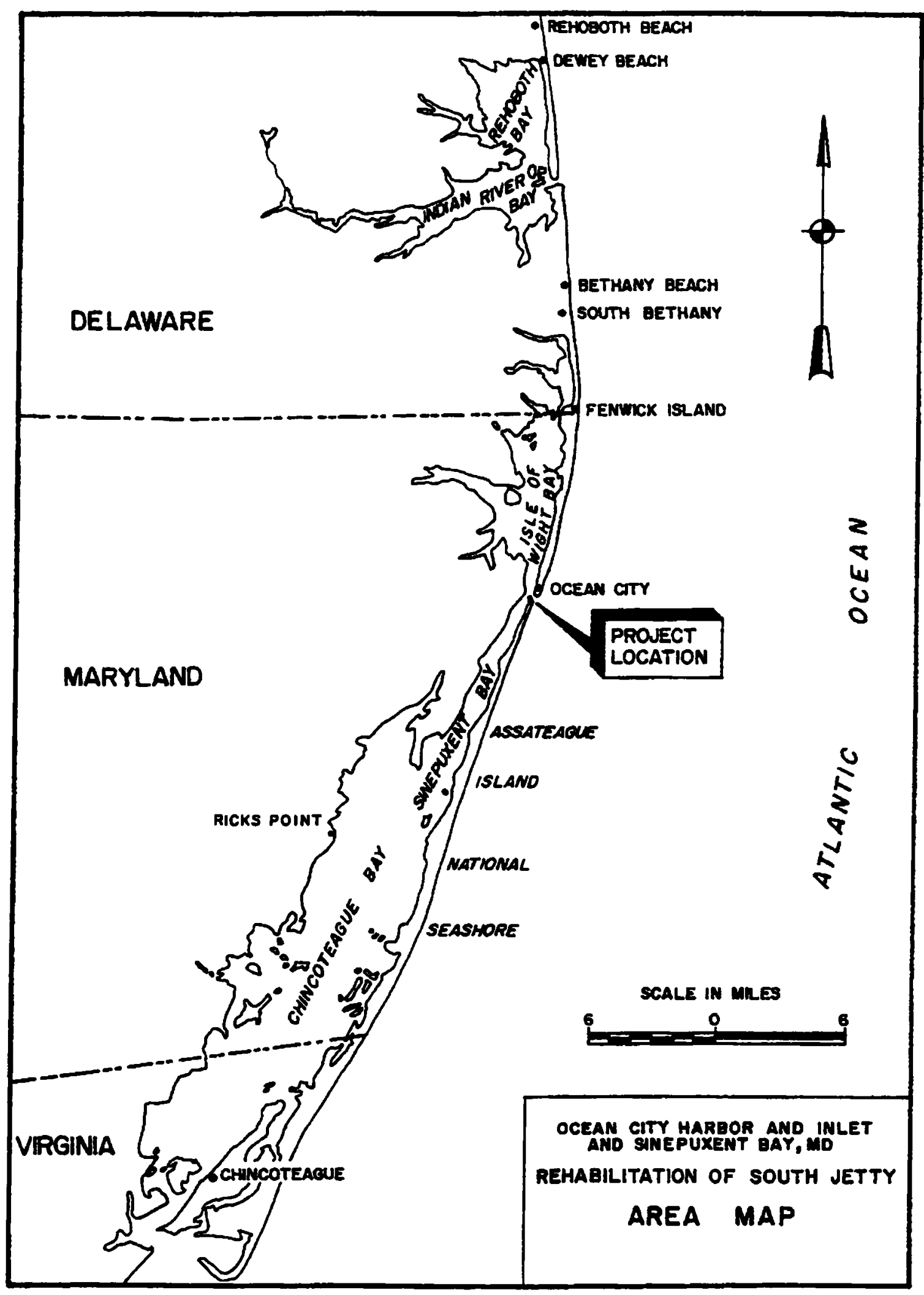

Figure 1. Area map showing the location of the project site 


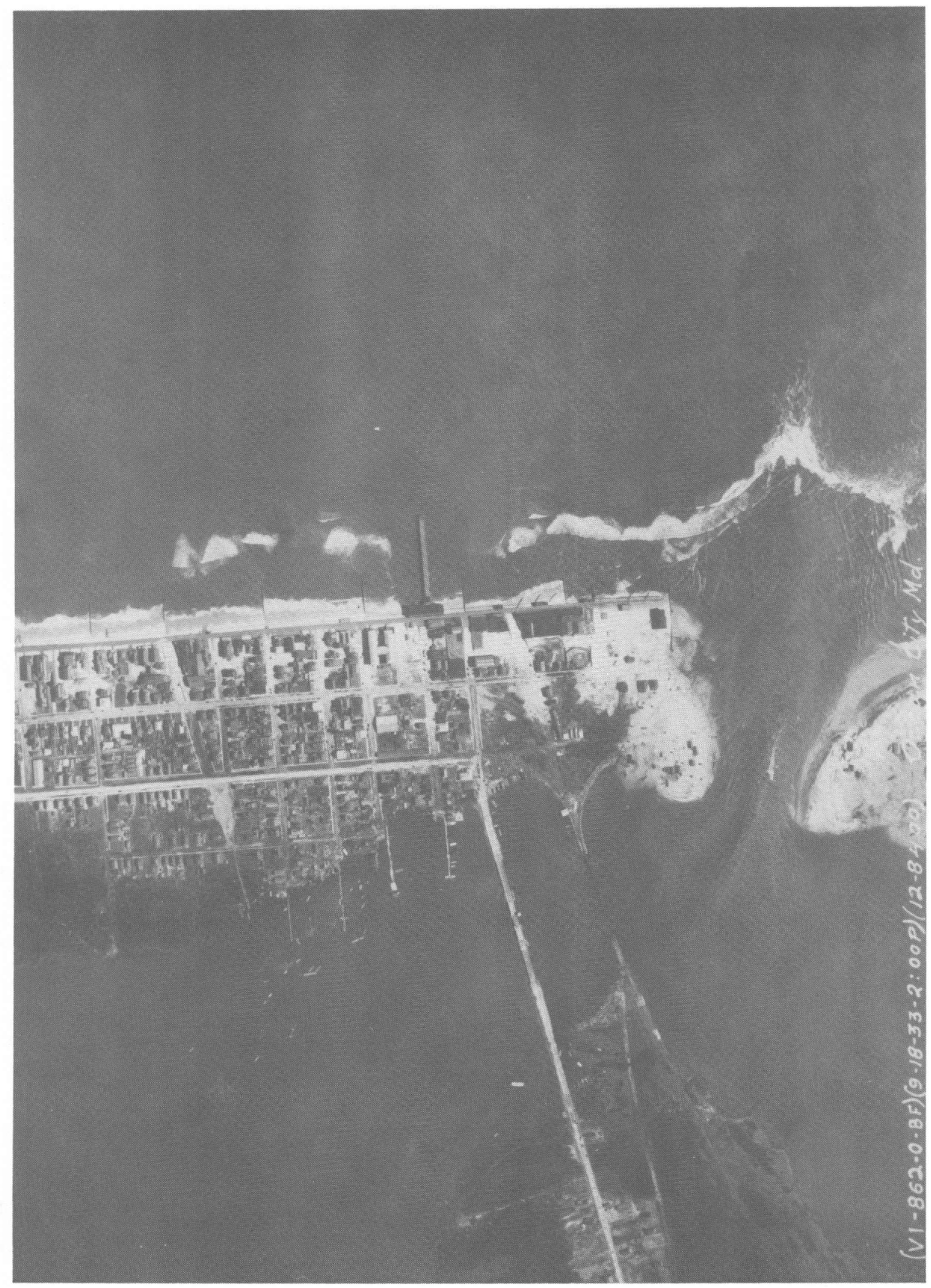

Figure 2. Condition of Ocean City Inlet on 18 September 1933 after its creation by a severe hurricane on 25 August 1933 


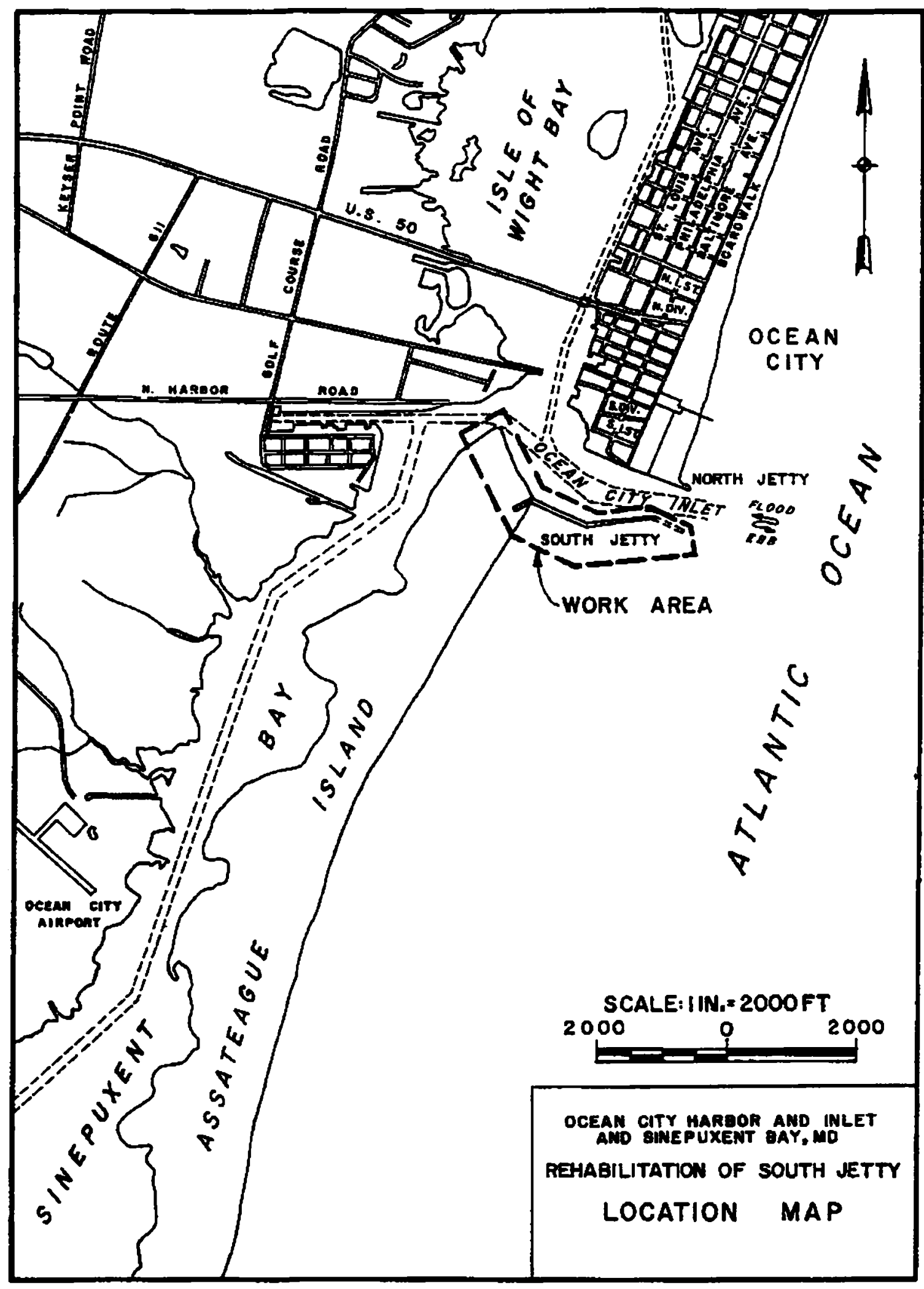

Figure 3. Location of the south jetty constructed in 1934 
The south jetty was constructed in 1935 with a crest elevation of +4.7 $\mathrm{ft}$ NGVD. The inshore section of the south jetty paralleled the north jetty for a distance of about $750 \mathrm{ft}$ at which point it trended towards the north jetty, decreasing the inlet width from $1,100 \mathrm{ft}$ to $600 \mathrm{ft}$. At this point, the south jetty again paralleled the north jetty for a length of $530 \mathrm{ft}$. The first $170 \mathrm{ft}$ of this $530-\mathrm{ft}$ section had a crest elevation of $+4.7 \mathrm{ft} \mathrm{NGVD.} \mathrm{The}$ elevation of the next $160 \mathrm{ft}$ of the south jetty decreased from $+4.7 \mathrm{ft}$ NGVD to the elevation of the "apron" section which was $4 \mathrm{ft}$ above the existing bottom. This apron section continued at this elevation for an additional $200 \mathrm{ft}$. Figures 4-6 show the condition of the inlet between 9 October 1934 and 6 December 1935.

Minor repairs were made to the south jetty from 1937 to 1938 . By this time, the inlet channel had migrated towards the south jetty and soon scoured the toe of the structure along an 800 -ft-long section of the outer end of the jetty. This damaged jetty was not rehabilitated immediately because the navigation channel was not significantly affected.

Following the north and south jetty construction, erosion of the northern Assateague Island shoreline increased as a result of sand starvation due to trapping of sediment by the north jetty. Recession rates on North Assateague Island were estimated to be about $35 \mathrm{ft}$ per year. This loss of sediment eventually resulted in erosion around the inshore end of the south jetty, which was repaired in 1956 by the placement of about 845 tons of stone. The erosion of Assateague Island continued at the above rate and, by 1961, resulted in additional erosion around the inshore end of the south jetty. This erosional condition was further aggravated by a 15 March 1962 northeaster, as shown in Figure 7, and required immediate rehabilitation. As a result, in 1963, the inshore end of the jetty was extended landward in a southwest direction for a distance of $680 \mathrm{ft}$. In addition, a 720-ft section previously damaged due to foundation scouring was repaired, starting $1,300 \mathrm{ft}$ seaward from the original landward jetty end.

Since Ocean City Inlet was naturally created and subsequently stabilized in 1934-1935, there have been numerous maintenance dredging events. Dredging requirements increased from an average annual amount of 10,000 to $15,000 \mathrm{cu}$ yd per year in $1969-1970$ to $50,000 \mathrm{cu}$ yd per year in 1971-1973. Between 1973-1985, the annual dredging requirements were approximately $30,000 \mathrm{cu}$ yd per year. Since inlet stabilization, approximately $6,000,000 \mathrm{cu}$ yd have been removed from the inner inlet shoals and deposited on Assateague Island.

Due to the frequent maintenance dredging requirements, the restricted navigation conditions between dredging events, and the continued scouring at the foundation of the outer end of the south jetty, a study was conducted by Dean and Perlin (1977) for the U.S. Army Engineer District (USAED), Baltimore, to determine the source of the shoaling problem and potential solutions for both the shoaling and scour problems. These studies concluded that due to the low height and permeability of the south 


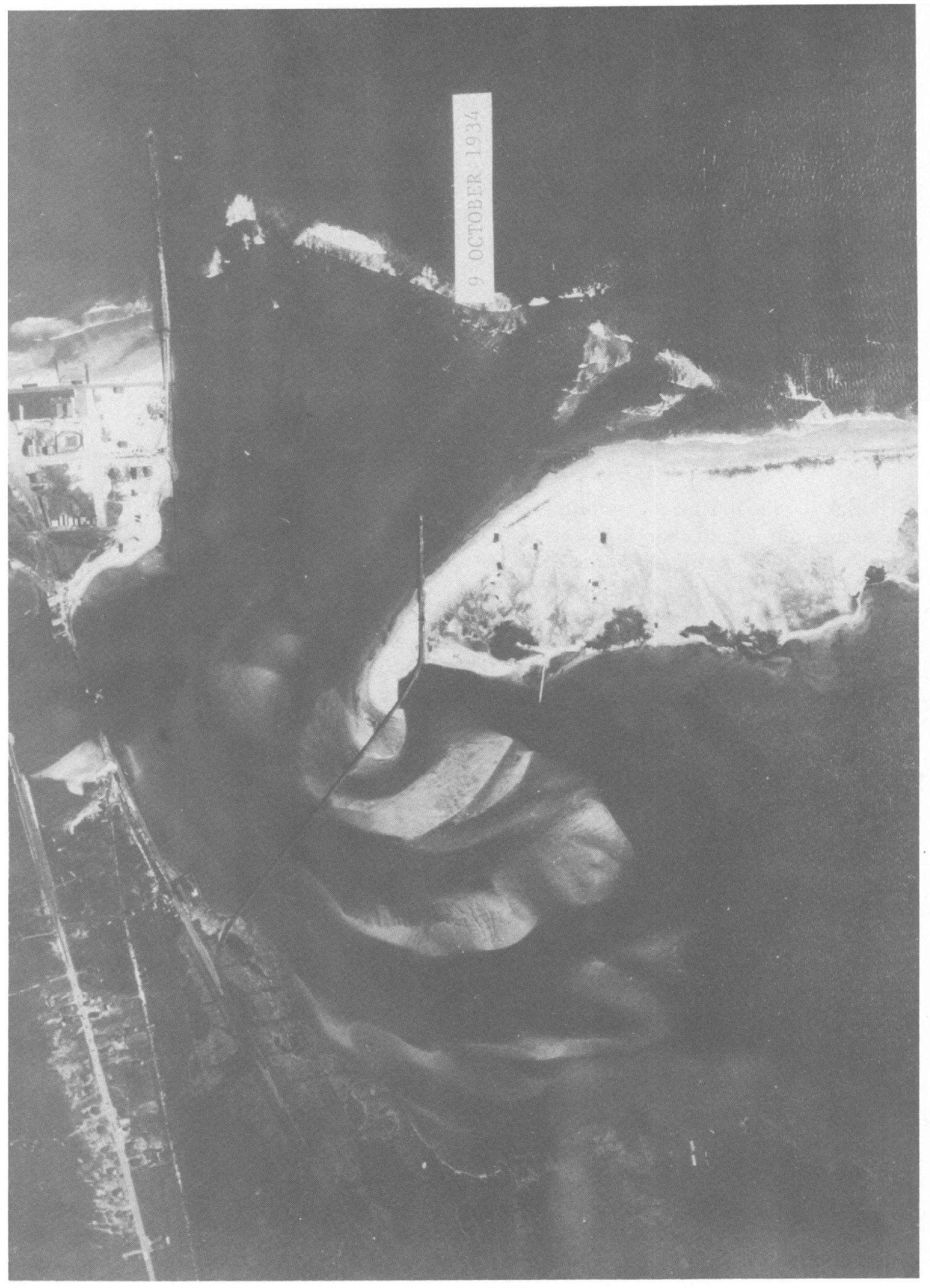

Figure 4. Condition of the inlet, 9 October 1934 


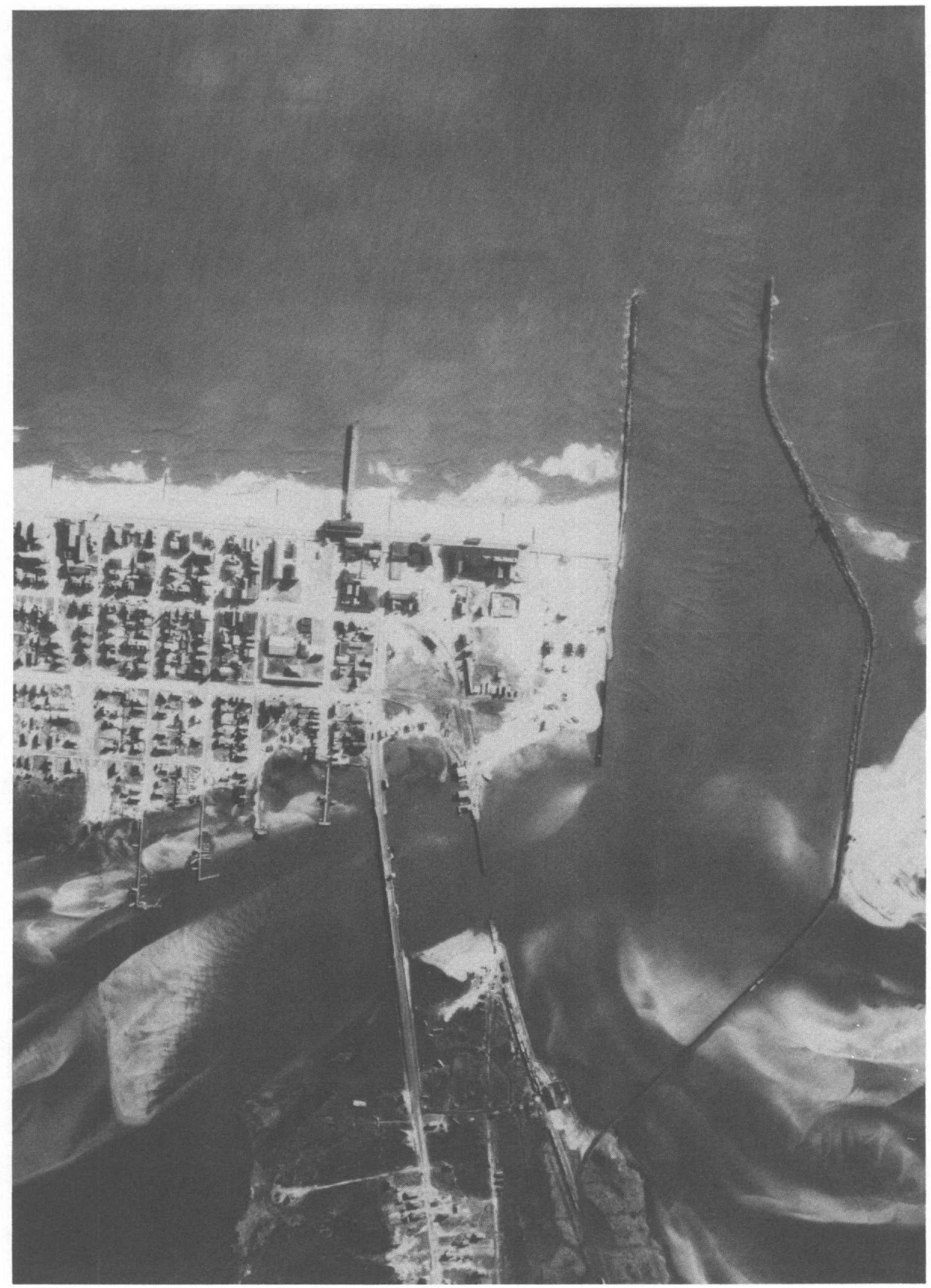

Figure 5. Condition of the inlet, 15 January 1935 


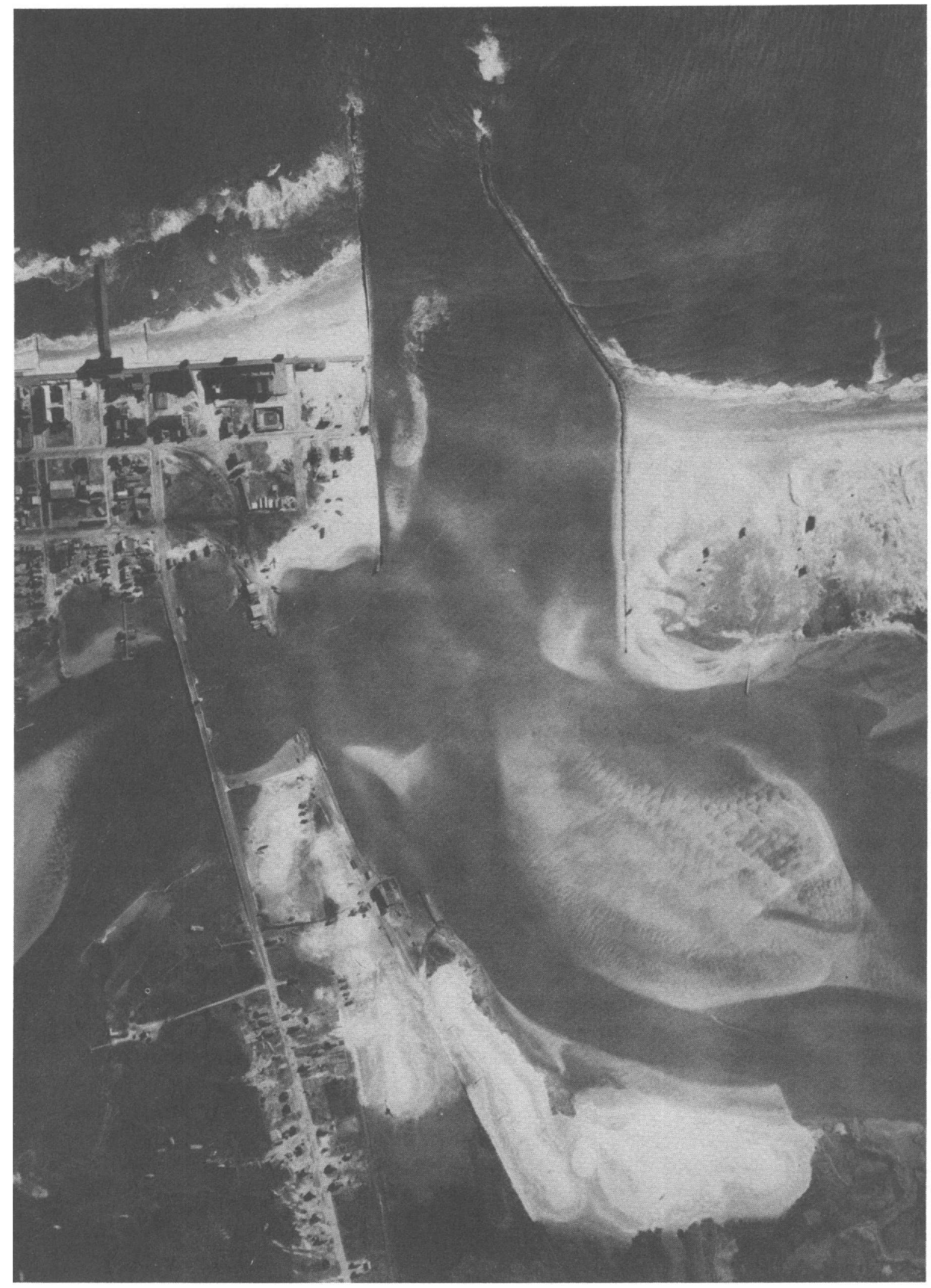

Figure 6. Condition of the inlet, 6 December 1935 


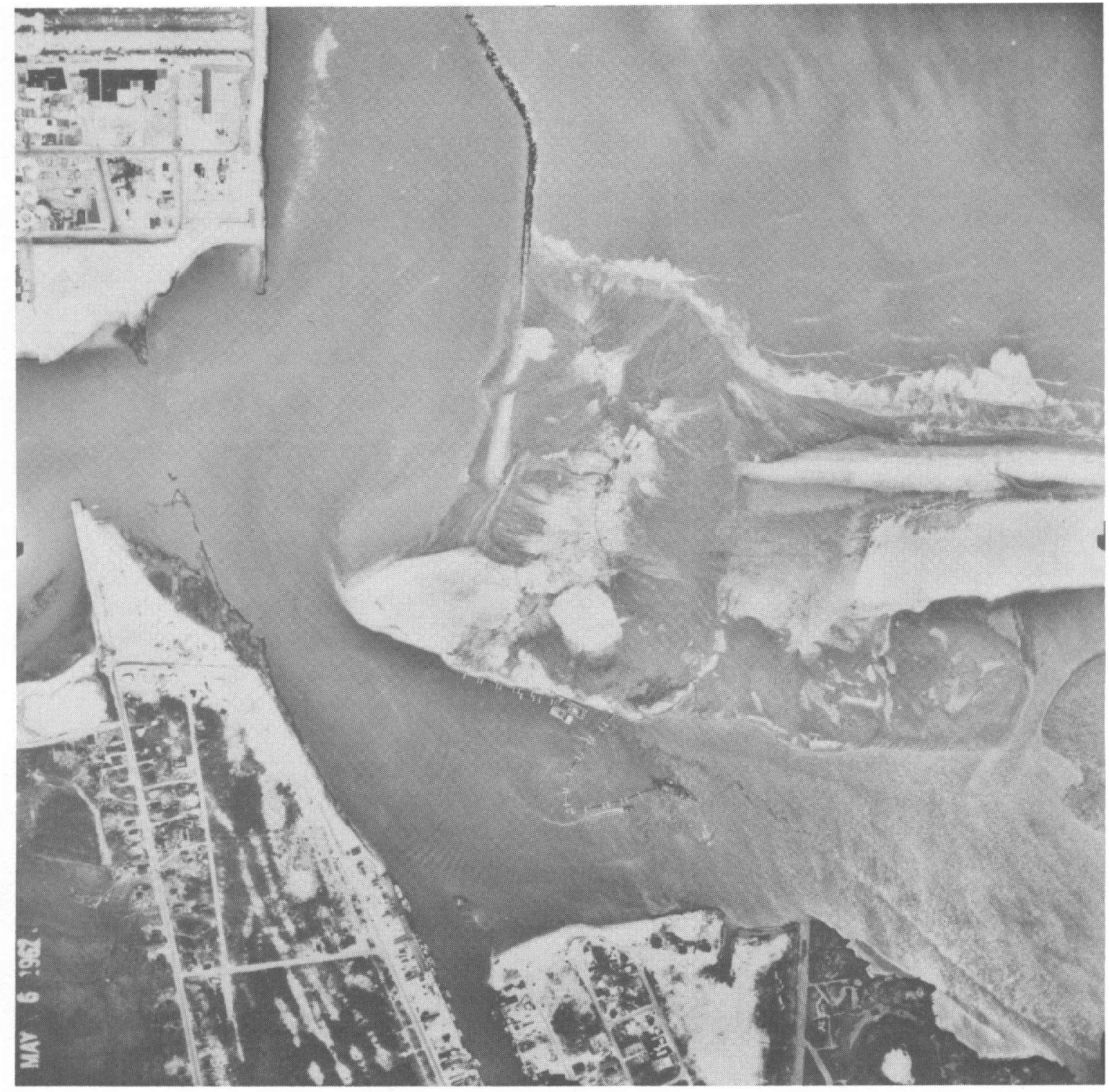

Figure 7. Condition of the inlet, 6 May 1962, showing erosion caused by a northeaster on 15 March 1962

jetty, significant quantities of sand were being transported northward along the shoreline of Assateague Island, and then through and over the nearshore section of the jetty. This sand eventually was being deposited inside the inlet, temporarily stored on the north end of Assateaque Island, and then transported north by ebb currents encroaching on the existing Federal navigation channel, as shown in Figure 8. 


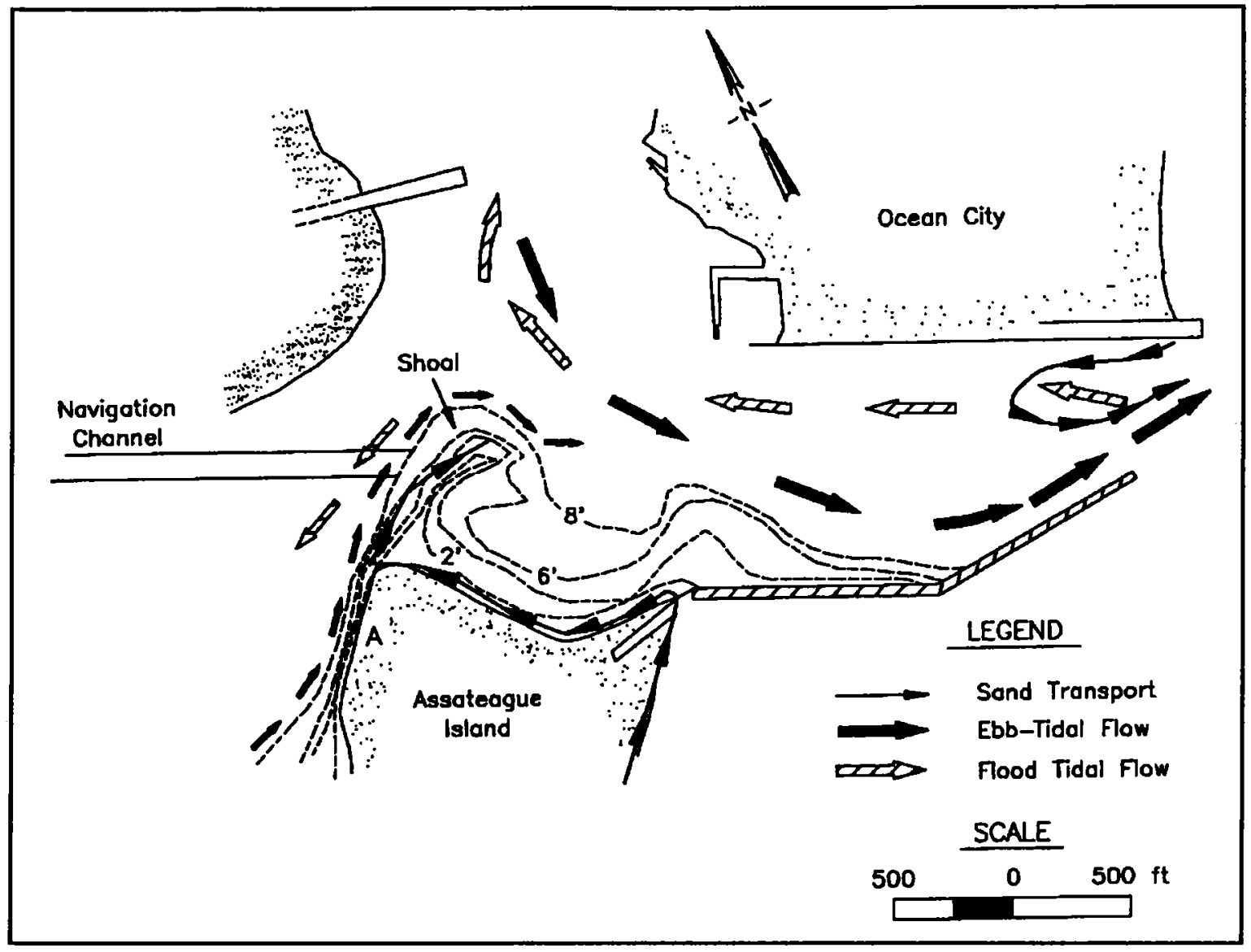

Figure 8. Schematic of the tidal currents and sand transportation patterns inside the inlet (Dean and Perlin 1977)

\section{Project Features}

\section{Jetty Rehabilitation}

The primary purpose of the project was the rehabilitation of the south jetty, creating a littoral barrier to eliminate or substantially reduce the inlet shoaling problem. The study conducted prior to project rehabilitation by Dean and Perlin (1977) concluded that the immediate source of the sand encroaching into the navigation channel was the ebb delta shoals located south of the main channel. This conclusion was reached after conducting sand tracer tests and swash measurements in the vicinity of the south jetty. Figure 8 indicates the sand transport pathway of this material. Dean and Perlin (1977) identified that northerly moving longshore sediment transport moved material through and over the inshore end of the south jetty. 
Field observations of the existing structure indicated that the capstone was located within the sediment transport zone, i.e., from the sand bottom to the spring tide water level, and that the associated void channels resulting from the capstone placement provided the pathway for the sand transport through the structure. In addition, the existing height of the jetty allowed transport of sand to overtop during higher tide occurrences.

After passing through and over the existing south jetty, sediment was transported by tidal and wave-induced currents along the northern shoreline of Assateague Island and resided temporarily as a shoal along the northwest shoreline of the island. From there, ebb-tidal currents from Sinepuxent Bay transported the sand northward towards the navigation channel where the stronger southerly moving ebb tidal currents from the Isle of Wight Bay were encountered and caused the sand to be transported and deposited into the problem shoal area. The localized northerly sand transport was determined to be a result of the sheltering effect of the north and south jetties and the wave transformation effects from the offshore ebb-tidal shoal.

To eliminate the shoaling, a new jetty section was constructed in 1985 , offset $30 \mathrm{ft}$ southward of the existing jetty centerline. The existing jetty was left intact. The new section was constructed of successive layers of bedding material, corestone, intermediate stone, one layer of capstone, and precast concrete units along the centerline to form a core impermeable to sand transport. Design studies (USAED, Baltimore 1982) indicated that a reasonable value for the maximum design wave height was $18 \mathrm{ft}$.

The south jetty was constructed with a bedding layer and a core of quarry run stone (w/200 to w/4000) covered by one layer of intermediate stone $(w / 10)$ and an exterior layer of large capstone $(w)$ where $w$ is the weight of the capstone armor units in pounds per cubic foot. The individual capstone weights were selected based on the stability formula developed by Hudson (1958). These weights are shown in Table 1.

\begin{tabular}{|l|l|}
\hline $\begin{array}{l}\text { Table } 1 \\
\text { Capstone Required for South Jetty } \\
\text { Rehabilitation }\end{array}$ \\
\hline Station & Allowable Weight Range \\
\hline $0+00$ to $7+50$ & $6-8$ tons \\
\hline $7+50$ to $9+50$ & $6-10$ tons \\
\hline $9+50$ to $12+83$ & $10-15$ tons \\
\hline Breakwaters & $3-5$ tons \\
\hline
\end{tabular}

The crest elevation of the new south jetty was increased from $+4.7 \mathrm{ft}$ NGVD to $+7.5 \mathrm{ft}$ NGVD. This elevation was determined to be the minimum crest height of the structure, as dictated by the capstone and 
underlayer widths required for stability under design wave conditions. A crest width equal to the combined widths of three capstone widths was selected for the jetty. These crest widths ranged between 16 and $18 \mathrm{ft}$.

Due to the large size of the capstone (6-15 tons) required for stability in this area, placement of the armor units to eliminate the void channels was not possible. Even if it were possible during initial placement, subsequent movement and/or settlement of the units would open up the voids between the units. The most obvious solution was to rebuild the jetty cross section with the capstone placed higher and out of the primary sediment transport zone. However, rebuilding the structure according to these criteria would have resulted in a height of about +12 to $+15 \mathrm{ft}$ NGVD, and would not have been cost-effective.

As a result, the selected approach was to rebuild the structure with the minimum crest height increase required to preclude significant sand transport overtop of the structure and to incorporate an impermeable core wall in the structure cross section. The minimum crest height was determined to be $+7.5 \mathrm{ft}$ NGVD.

The impermeable core wall along the centerline consisted of rectangular precast concrete units. These units were $6 \mathrm{ft}$ wide by $2 \mathrm{ft}$ long by 5 to $6 \mathrm{ft}$ high and included steel reinforcement for strength. A 2-ft-long tongue-in-groove interlock joint was used to maintain alignment and impermeability between units. A series of figures shows the design plans of the south jetty. Figure 9 depicts the plan view. Figure 10 illustrates the profile, and Figure 11 shows typical cross sections of these features.

\section{Scour Hole Stabilization}

A numerical model analysis was performed on the inlet hydraulics and associated shoaling patterns. This study determined that the existing alignment of the outer jetty section was necessary to maintain the sediment flushing ability of the inlet. It was also determined that the outer section of the jetty, although in raveled condition, was not contributing to the shoaling problem in the navigation channel north of Assateague Island (the primary reason for the jetty rehabilitation). Thus, rehabilitation of the outer jetty section was not needed to solve the shoaling problem.

However, the numerical model analysis indicated that failure of sections of the outer south jetty induced by enlargement of the scour hole immediately north of the south jetty beginning at about sta $15+00$ would result in a significant increase in shoaling in the inlet. This increased shoaling would be at the throat of the inlet between the existing ends of the north and south jetties. Because of the shoaling and the submerged stone resulting from the failure of the outer jetty section, navigation through the inlet would be very hazardous. Stability analyses indicated that the existing outer jetty section was marginally stable. Any 


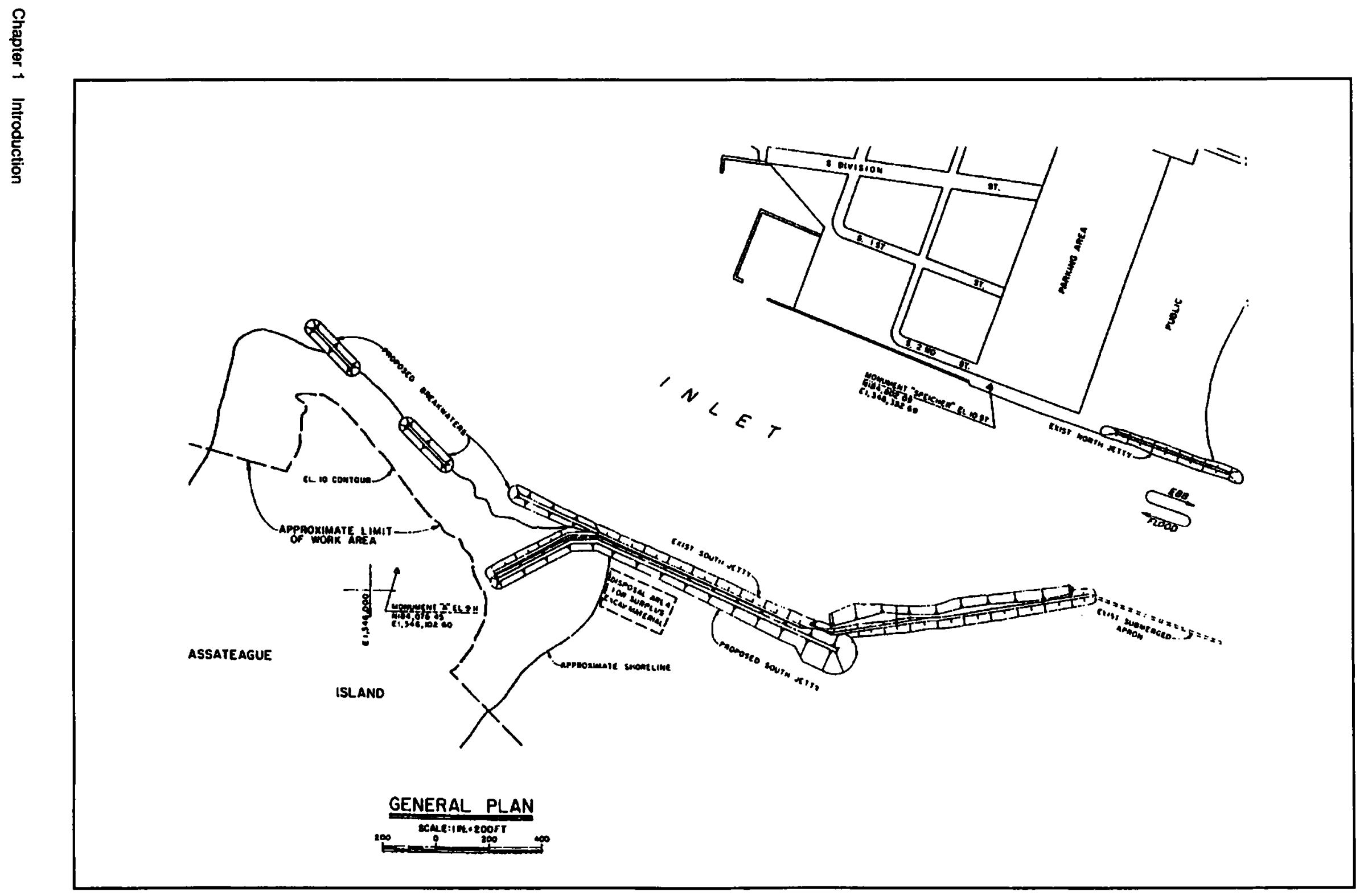

$\vec{\omega} \quad$ Figure 9. Plan view of the reconstructed south jetty 


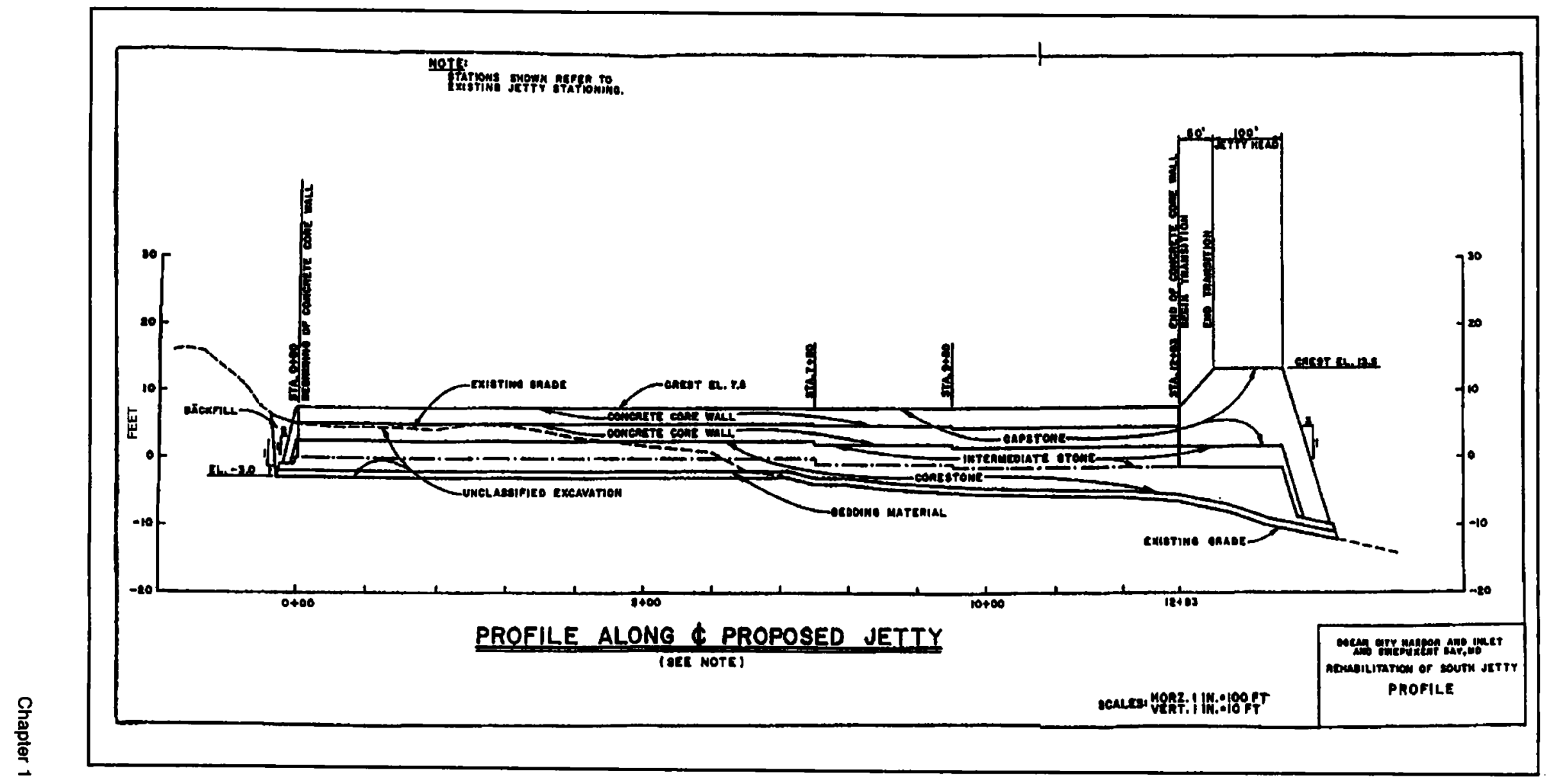

Figure 10. Profile of the reconstructed south jetty 

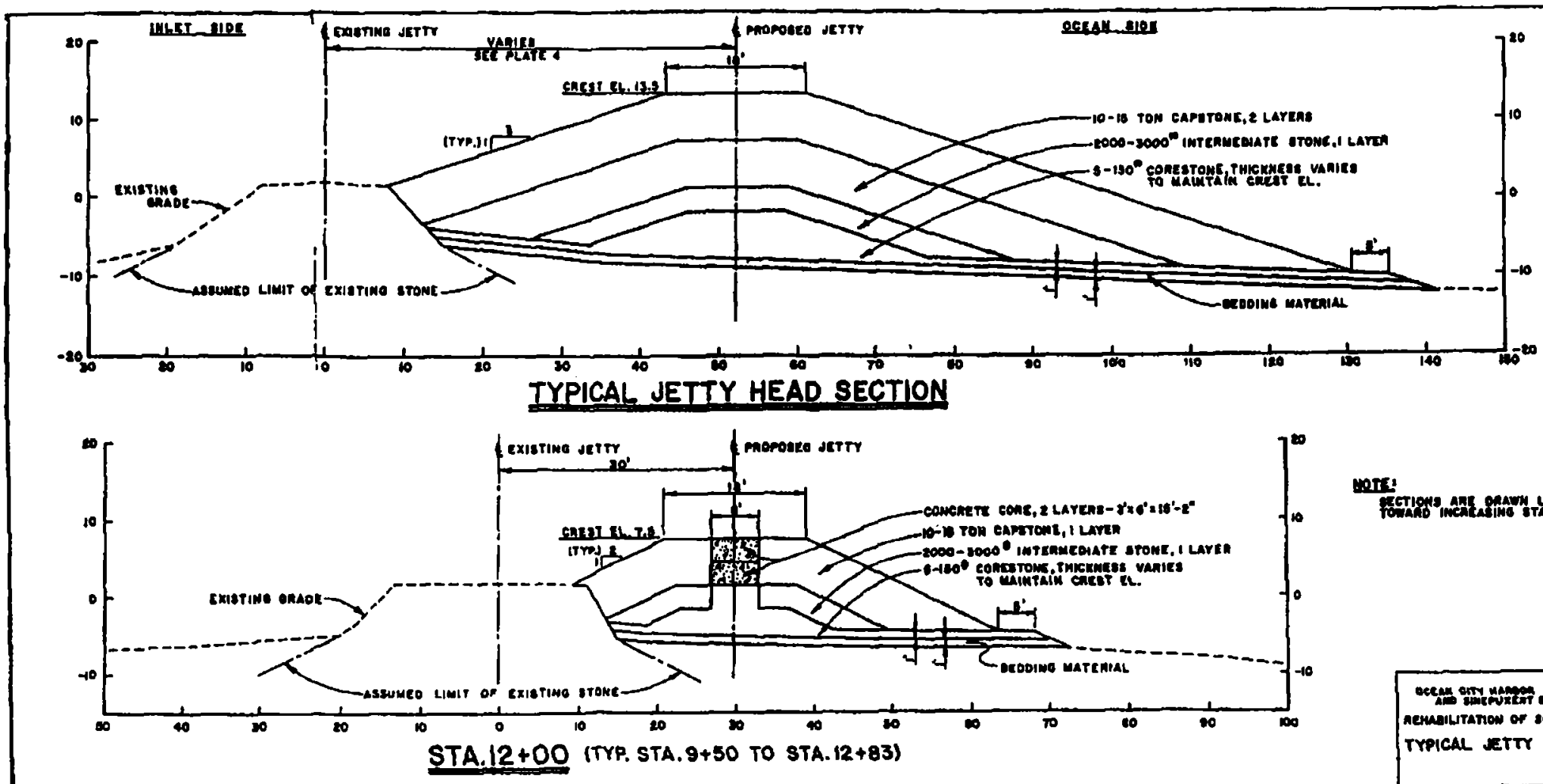

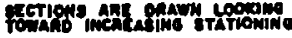

Figure 11. Typical cross-section of the reconstructed south jetty, elevations in feet (NGVD) 
enlargement of the scour hole area would decrease this marginal stability and eventually lead to failure.

To prevent this failure, the scour hole was filled with sand hydraulically, as shown in Figure 12, to elevation $-30.0 \mathrm{ft} \mathrm{NGVD} \mathrm{and} \mathrm{then} \mathrm{ar-}$ mored with a protective blanket composed of several layers of 50 - to 200-lb stone. The elevation of the fill was limited to - $30 \mathrm{ft} \mathrm{NGVD,} \mathrm{in-}$ stead of the original design elevation of $-20.0 \mathrm{ft}$ NGVD, to facilitate construction. In addition, an armored stability berm was placed on the inlet side of the jetty from sta $14+50$ to sta $23+00$. These features are shown in Figure 12.

\section{Northern Assateague Shoreline Stabilization}

The existing sand transport over and through the low and permeable south jetty provided a stabilizing effect on the northern shoreline of Assateague Island inside the inlet. By rendering the structure sand-tight, the source of material in the problem shoal would be eliminated, or at least significantly reduced. Due to the elimination of this source of sand, it was anticipated that the northern shoreline of Assateague Island would begin to erode rapidly due to tidal current and wave action. Shoreline recession could have eventually reached the inshore tie-out of the jetty and resulted in a breach which would allow significant quantities of sand to be transported into the navigation channel.

To stabilize this shoreline area, three headland breakwaters were constructed. Each of these breakwaters was constructed by placing successive layers of bedding materials, corestone, intermediate stone, and capstone to an elevation of +6.0 NGVD with side slopes of 1 vertical on 2 horizontal. The crest width of each breakwater was $12 \mathrm{ft}$. The plan view and typical cross sections of the breakwaters are shown on Figures 13 and 14 , respectively. Breakwater No. 1 tied into the existing south jetty at about sta $4+36$ and was $340 \mathrm{ft}$ long. Breakwaters No. 2 and 3 were $200 \mathrm{ft}$ long. The spacing between the breakwaters was $300 \mathrm{ft}$.

The construction cost for the rehabilitation project was $\$ 5.9$ million. The construction of the project was completed in December 1985. The plan detailed above was expected to eliminate or significantly reduce the shoaling problem in the Federal navigation channel leading into West Ocean City Harbor. 


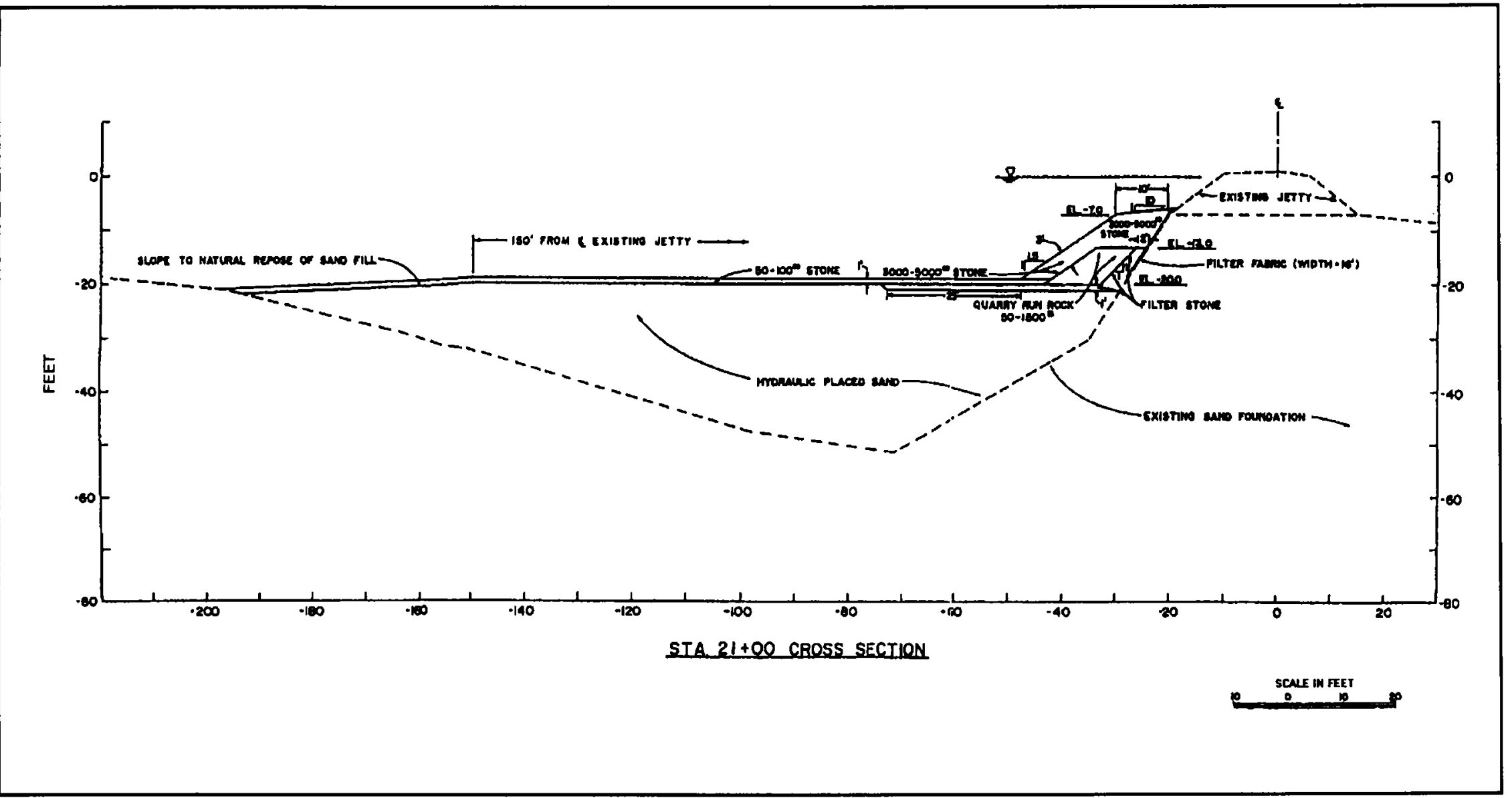

Figure 12. Cross-section of the filling in on the scour hole and placement of pound stone 


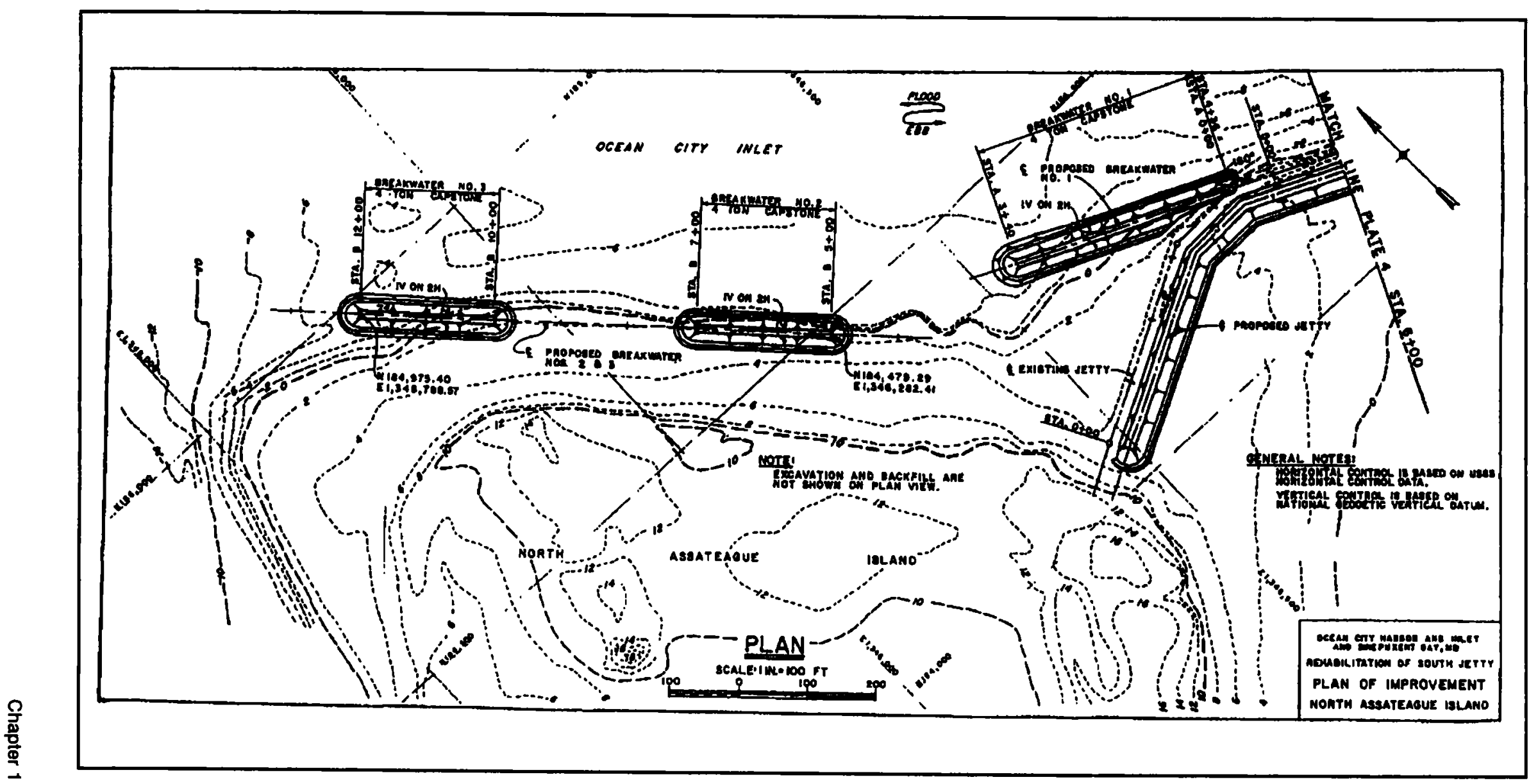

Figure 13. Plan view of the three breakwaters constructed to protect the northern end of Assateague Island 


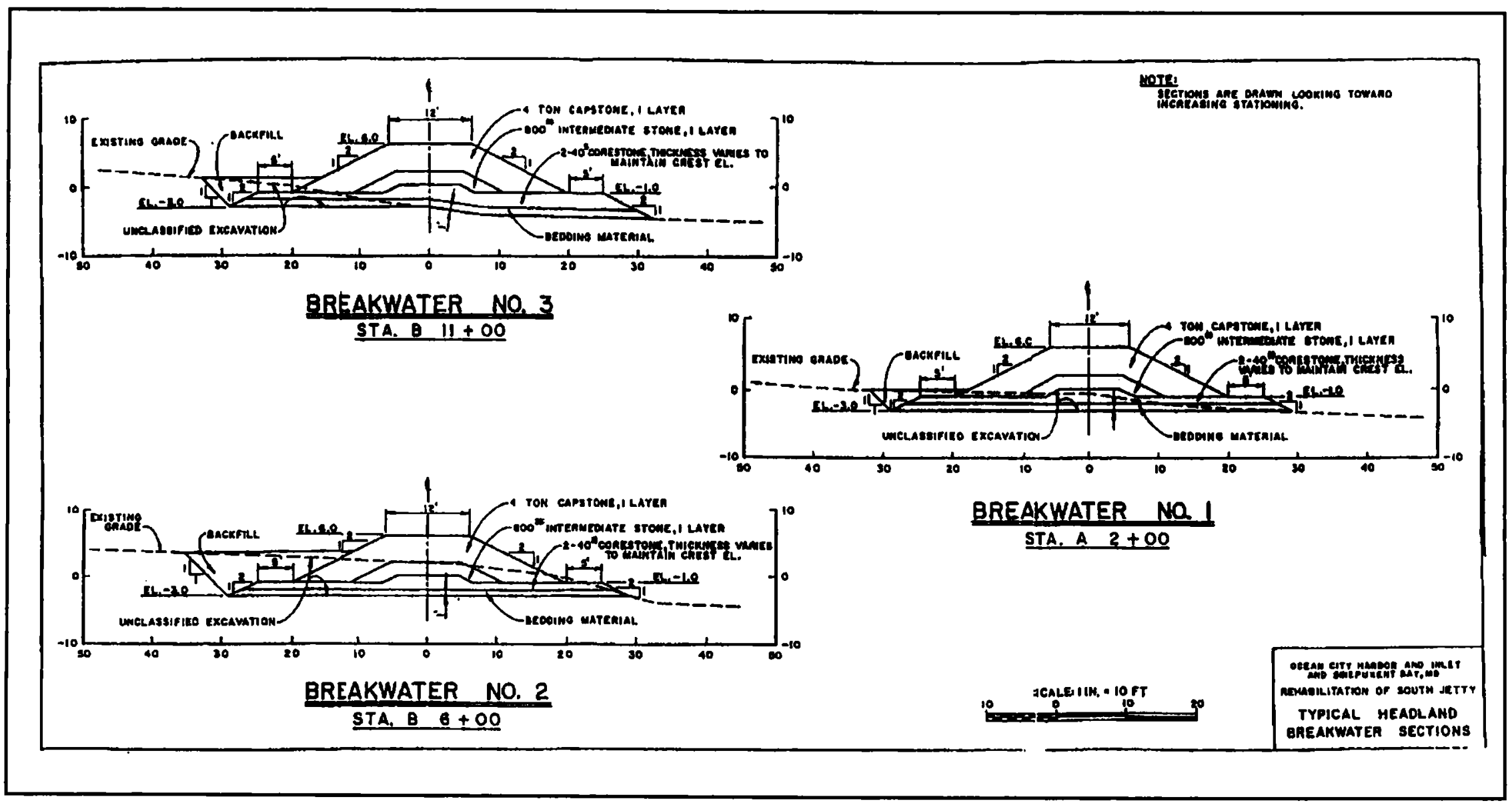

Figure 14. Typical cross-section of the breakwaters 


\section{South Jetty Monitoring Program}

\section{Monitoring Completed Coastal Projects (MCCP) Program}

The South Jetty Monitoring Program was selected for study as part of the Monitoring Completed Coastal Projects (MCCP) program. The goal of the MCCP program is the advancement of coastal engineering technology. It is designed to determine how well projects are accomplishing their designed purpose and withstanding waves and currents. These determinations, combined with concepts and understanding already available, will lead to upgrading credibility of predicting cost-effectiveness of engineering solutions to coastal problems; strengthening and improving design criteria and methodology; improving construction practices; and improving operation and maintenance techniques.

\section{Objectives}

Originally, there were six basic objectives of the South Jetty Monitoring Program: (1) verification of the studies relating to the cause of the problem shoal; (2) evaluation of the effectiveness of the rehabilitated jetty cross-section as a littoral barrier; (3) evaluation of the effectiveness of the shoreline stabilization on the northern shoreline of Assateague Island; (4) verification/calibration of the Shore Protection Manual Longshore Transport Formula; (5) examination of the distribution of longshore transport across the surf zone; and (6) analysis of the shoreline and profile response following rehabilitation of the jetty. However, two additional objectives were identified during the course of the monitoring program: (7) evaluation of ebb shoal equilibrium and northern Assateague Island growth; and (8) evaluation of scour hole stabilization. 


\section{Data Collection}

The South Jetty Monitoring Program extended over a 27-month period from October 1986 through January 1989. The primary activities comprising the effort were beach and offshore profile surveys, aerial and ground photography of the inlet and adjacent shorelines, hydrographic surveys of the inlet, continuous nondirectional wave gauging, and side scan sonar surveys of the scour protection area.

Deepwater wave data (nondirectional) were obtained during the monitoring program with a Datawell Waverider buoy located in about 50 $\mathrm{ft}$ of water northeast of the south jetty as shown in Figure 15. Due to prohibitive winter weather conditions, the deployment of the Waverider buoy was delayed until 2 April 1986. A shore-based receiver station was established in the Ocean City Life Saving Museum located at the southern end of the boardwalk. Wave data transmission from the Waverider buoy to the receiving station was initiated and continued until 6 November 1987. From 2 April to 6 November, 18 days of downtime due to communication problems were encountered. Between 12 September 1986 and 4 December 1986, the Waverider buoy was inoperable due to malfunction of the shore-based receiver. On 4 December 1986, the buoy resumed operation and provided wave data until 23 January 1987. The gauge was lost sometime between the end of January and the end of February 1987 and has not been recovered.

On 25 February 1987, a second Waverider buoy was deployed in the approximate location of the previous gauge. Receiver problems occurred again in mid-April 1987 and were resolved by 28 April 1987. The wave data collected during the monitoring program are presented in Appendix A.

On 27 August 1986, the Coastal Engineering Research Center (CERC) deployed and initiated operation of a directional wave gauge about $1 / 2$ mile offshore of Ocean City. This location was selected instead of the planned location due to concern that the wave gauge would be struck by commercial fishing boats navigating through the study area. Two subsequent wave gauge deployments were made on 17 November 1986 and 22 February 1987. The first two deployments (27 August and 17 November) were unsuccessful due to electronic problems with the wave gauges. The last deployment, which lasted until 12 May, was successful in collecting wave data. The data collected from this instrument were to be used in the determination of longshore sediment transport distribution across the surf zone for the Ocean City area. These data are presented in Appendix B.

Fifteen beach profiles shown in Figure 16 and listed in Table 2 were surveyed out to the -30-ft NGVD contour (where applicable) in order to capture depth of closure. During 16-23 May 1986, a horizontal and vertical control survey for the offshore profiles along the northern end of Assateague Island was completed. Surveys of the profiles were conducted on the following dates: 


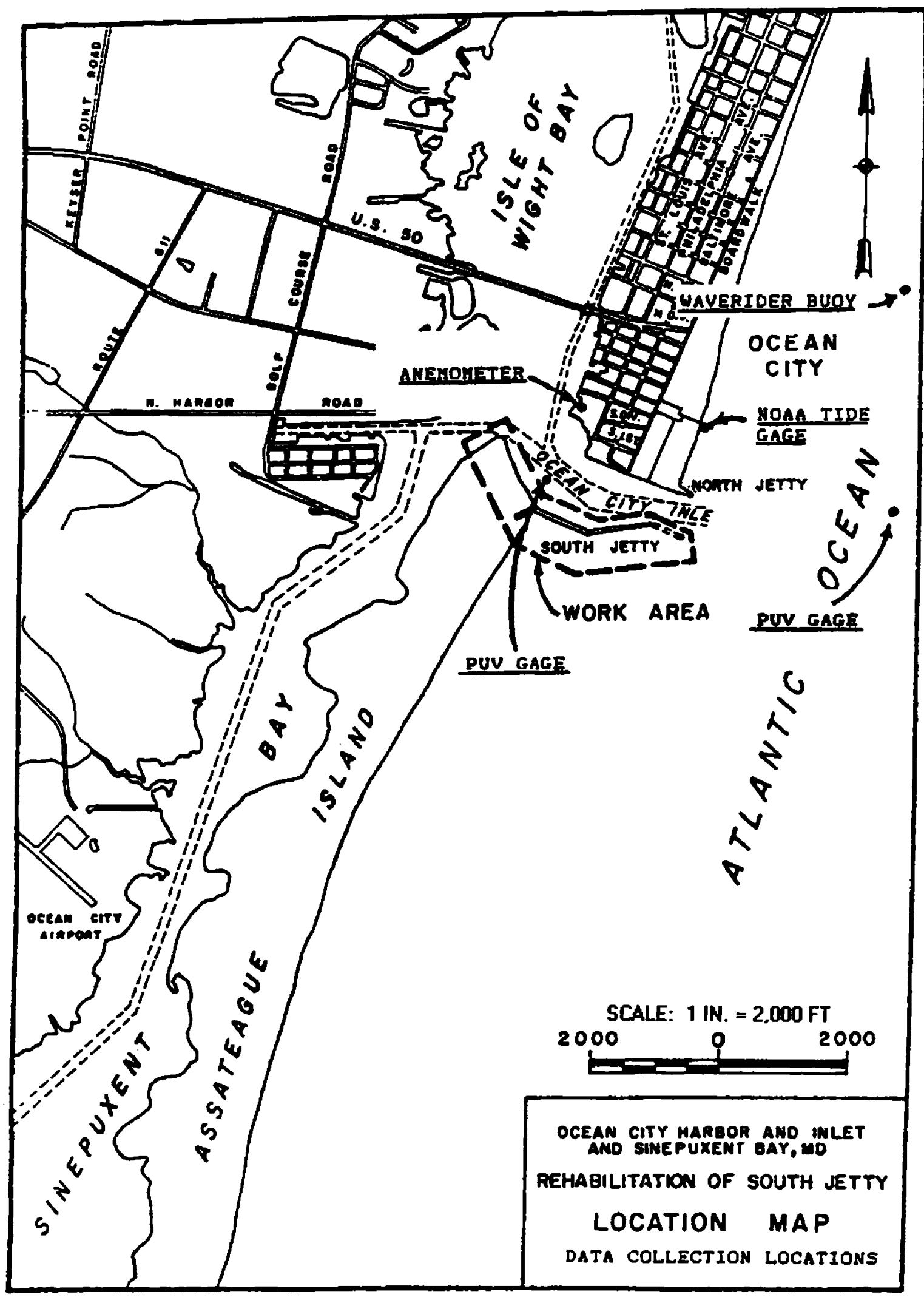

Figure 15. Location of data collection instruments used in study 


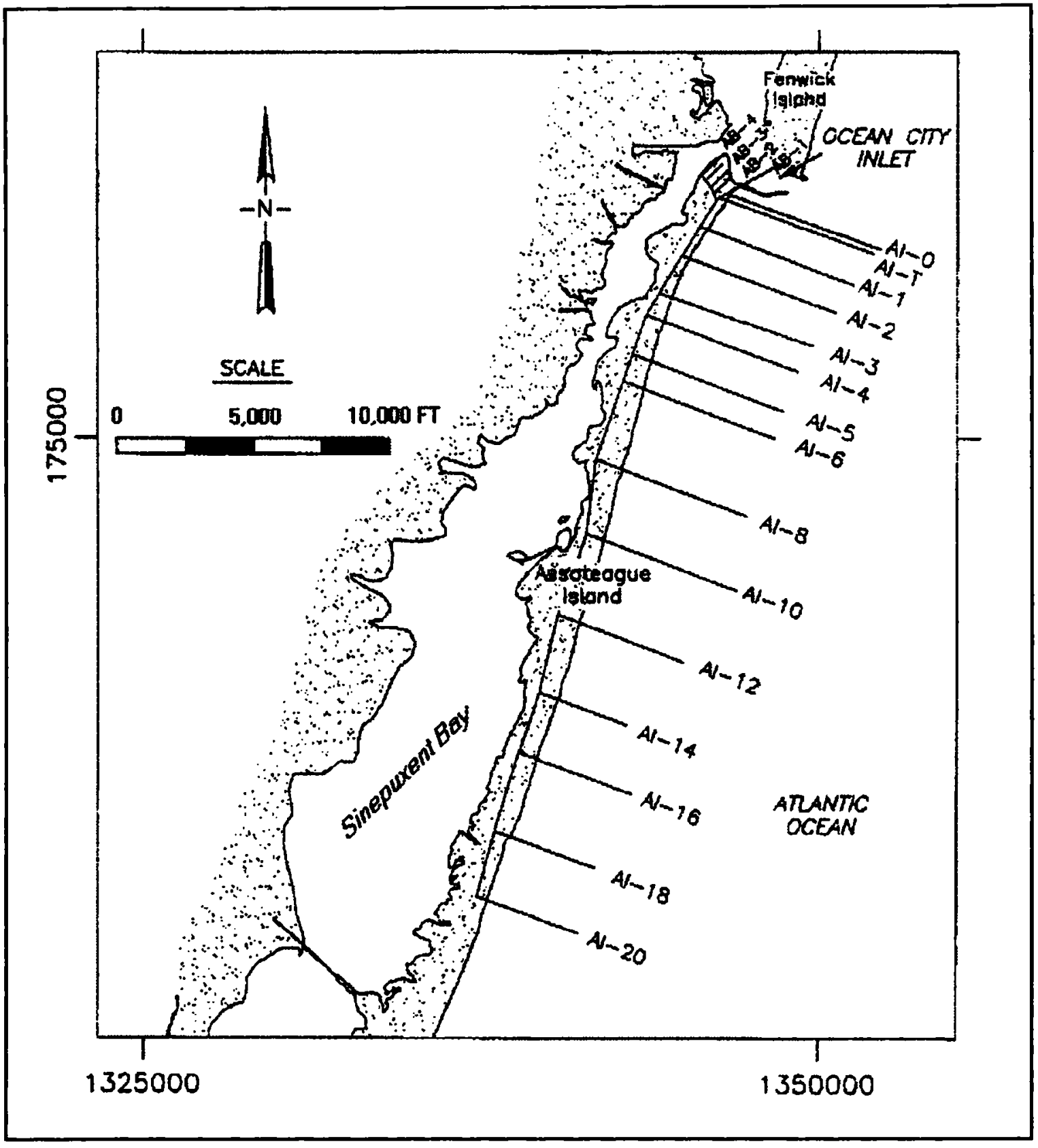

Figure 16. Location of the 19 profile sites monitored
a. June 1986.
b. October 1986.
c. August 1987.
d. January 1989. 


\begin{tabular}{|l|l|l|l|}
\hline \multicolumn{4}{|l|}{ Table 2 } \\
Assateague Island Shoreline Changes Along Profiles, $\mathrm{ft}$ \\
\hline Proflle & Jun 86 - Oct 86 & Oct 86 - Aug 87 & Aug 87 - Jan 89 \\
\hline Al-0 & +75 & -50 & +51 \\
\hline Al-T & -204 & +130 & +43 \\
\hline Al-1 & +33 & -20 & +75 \\
\hline Al-2 & +15 & +10 & -2 \\
\hline Al-3 & +45 & -35 & -13 \\
\hline Al-4 & -5 & +6 & -12 \\
\hline Al-5 & -1 & -12 & -3 \\
\hline Al-6 & -8 & -11 & 4 \\
\hline Al-8 & -5 & -17 & +13 \\
\hline Al-10 & +2 & -22 & -7 \\
\hline Al-12 & -1 & -19 & -11 \\
\hline Al-14 & -5 & -31 & -28 \\
\hline Al-16 & +20 & -48 & +35 \\
\hline Al-18 & +17 & -35 & +37 \\
\hline Al-20 & 0 & -17 & +5 \\
\hline
\end{tabular}

A comparison of these surveys is presented in Appendix C.

Hydrographic surveys of the navigation channel through Ocean City Inlet were obtained as part of the operation and maintenance program.

Side scan sonar surveys were obtained to monitor the performance of the toe of the rehabilitated jetty, the stability berm on the outer section of the jetty, and the armor layer covering the scour hole area. These surveys were conducted in August 1984 and June 1990.

Periodic aerial photography of the inlet area and the northern $45,000 \mathrm{ft}$ of Assateague Island was obtained to evaluate the response of the inlet and shoreline to the jetty construction. The aerial photography was taken at mean low tide and provided as 9 -in. by 9 -in. color prints with 20 percent overlap coverage at a scale of 1 in. $=400 \mathrm{ft}$. Photography was obtained on the following dates:

a. 29 August 1986. 
b. 23 December 1987.

c. 9 April 1989.

d. 21 February 1990. 


\section{Results}

\section{Shoreline Change Maps}

Shoreline change maps were prepared to evaluate the changes of the Atlantic Ocean shoreline and Ocean City Inlet shoreline of the northern end of Assateague Island. A field survey of the northern end of Assateague Island was conducted on 6-7 March 1990 and was used as the base map. This survey was conducted using a Topcon HA-3 Data Collector and GTS3 Total Survey Station. The baseline traverse set up for the profile surveys was used for this survey.

The survey data file was transferred directly from the data collector into an AutoCad Version 10 computer file. The data were then reduced and contoured using DCA engineering software, and base maps were prepared at scales of $1 \mathrm{in} .=100 \mathrm{ft}$ and $1 \mathrm{in} .=200 \mathrm{ft}$.

The mean high water ( $\mathrm{mhw}$ ) shorelines from the four aerial photography flights (August 1986, December 1987, April 1989, and February 1990) were then digitized and added to the AutoCad file containing the base maps. The aerial photography was not developed at a precise scale using ground truth due to cost limitations of the program. However, the photography was developed at an approximate scale of 1 in. $=400 \mathrm{ft}$ based on the flight elevation. After entering the aerial photography shorelines into the AutoCad system, measures to improve the locations of the shorelines were investigated. Essentially, consideration was given to adjusting the scale of each set of photographs to match known distances between prominent features such as the jetty and breakwaters. However, analysis of the four frames composing each aerial flight revealed variations in scale between several of the frames in some cases. This situation, combined with the lack of known distances between prominent features in the frames south of the jetty area, precluded adjusting the scale for the overall flight. Consequently, no corrections were made to the photography. As a result, some error in the shoreline position on the maps is induced, particularly considering the subjectivity of locating the mhw shoreline on the photographs. It is estimated that the error associated with the aerial photography shoreline location is on the order of $\pm 10 \mathrm{ft}$. For 
the purposes of this report, the accuracy of the locations is considered adequate.

The four profile surveys (May 1986, October 1986, August 1987, and January 1989) were available in Interactive Survey Reduction Program (ISRP) format computer files and were converted to ASCII computer files and then imported into the AutoCad system. MHWL contours $(+1.75 \mathrm{ft}$ NGVD) were located on each survey and then added to the shoreline change maps. However, due to some problem with the traverse control, the shoreline locations from the ISRP profiles were suspect and subsequently removed from the maps. The project shoreline change maps are presented in Appendix D.

\section{Conclusions Relating to the Cause of the Problem Shoal}

Comprehensive preconstruction studies (USAED, Baltimore 1982) were conducted concluding that the problem shoal, shown in Figure 8, was a result of sand transport through and over the nearshore section of the existing south jetty.

As part of the construction of the project, the finger shoal area that was interfering with navigation was dredged and used as fill in the scour hole adjacent to the outer leg of the south jetty. Analysis of the aerial photographs of the inlet taken on 29 August 1986 and 23 December 1987 (Figures 17 and 18, respectively) shows no indication of the reoccurrence of the shoal. During this time period, no reports of navigational difficulties in the shoal area were received.

Analysis of the photographs indicates that the northwest shoreline of Assateague Island leeward of Breakwater No. 3 underwent significant erosion between 29 August 1986 and 23 December 1987. Prior to construction of the rehabilitated jetty and the headland breakwaters, the northwest shoreline remained stable. Sand was continually being transported to the northwest shoreline area through and over the south jetty and along the inlet shoreline. Upon reaching the northwest shoreline area, the sand deposited until ebb tidal currents eroded the material from the shoreline and deposited it in the problem finger shoal. By virtue of the erosion of the northwest shoreline following construction, it appears that this shoreline is no longer being nourished by transported sand since the south jetty has been sand tightened. Consequently, it appears that the conclusion of the preconstruction studies was correct in identifying the source of the shoal.

Analysis of aerial photographs taken on 9 April 1989 and 21 February 1990 (Figures 19 and 20, respectively) indicates that the northwest shoreline segment continued to erode and by the latter date had achieved somewhat of an equilibrium orientation similar to the planforms formed 


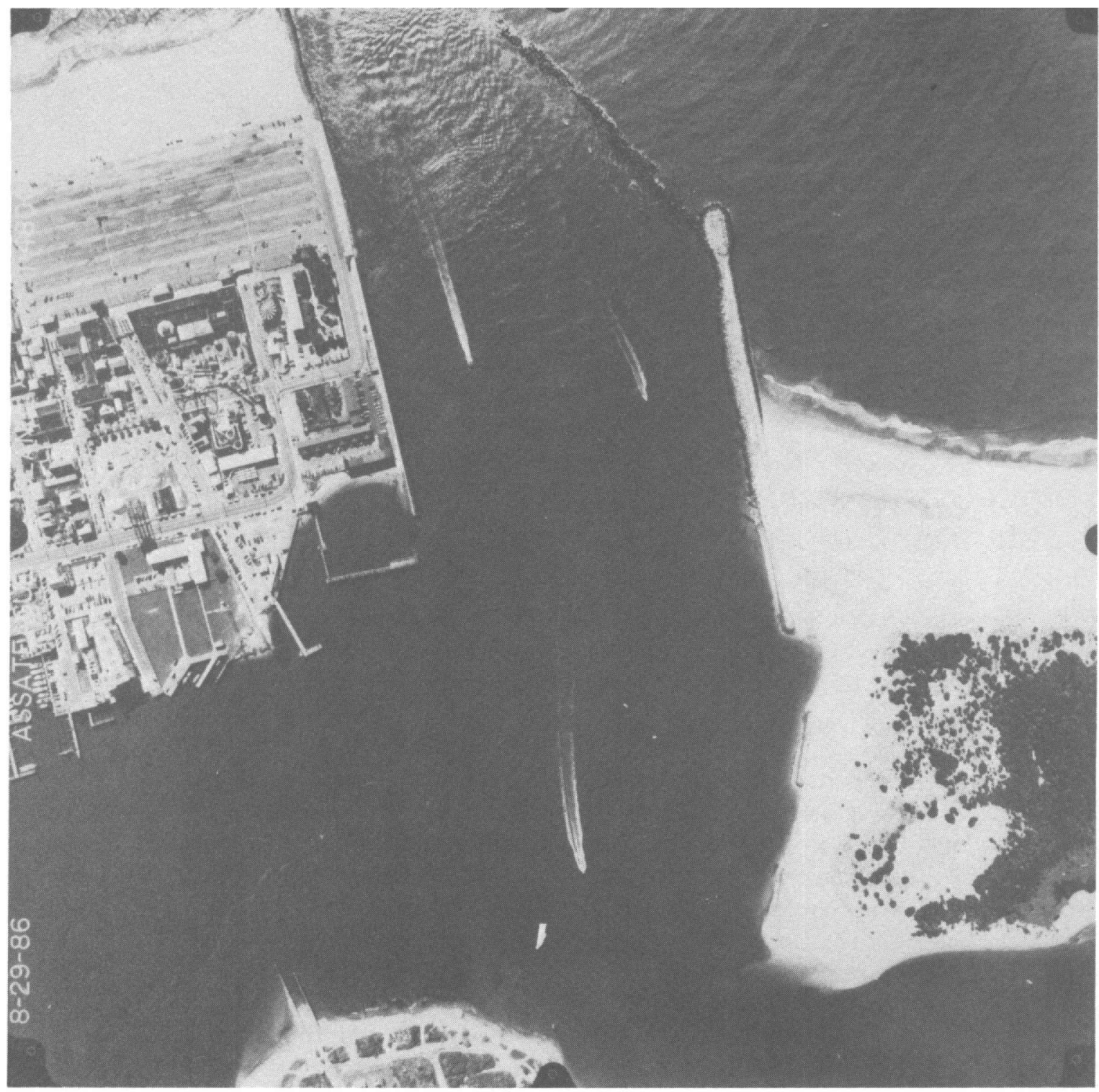

Figure 17. Condition of inlet on 29 August 1986 after the jetty reconstruction showing no indication of the reoccurrence of the shoal

between the headland breakwaters. The formation of a finger shoal first identified in the 9 April 1989 photograph is clearly shown in the 21 February 1990 photograph. This shoal apparently formed from the eroding shoreline caused by the ebb tidal currents that previously formed the problem shoal. However, the orientation of this shoal is aligned more to the east than the previous problem shoal, possibly due to the diffraction of the current around the end of Breakwater No. 3. Consequently, the shoal does not interfere with navigation into or out of West Ocean City Harbor.

Based on the 21 February 1990 photograph, it appears that the shoreline leeward of Breakwater No. 3 is approaching an equilibrium orientation, and that continued erosion of the shoreline contributing to the shoal area is not likely. It is recommended that the shoal area be dredged during the 


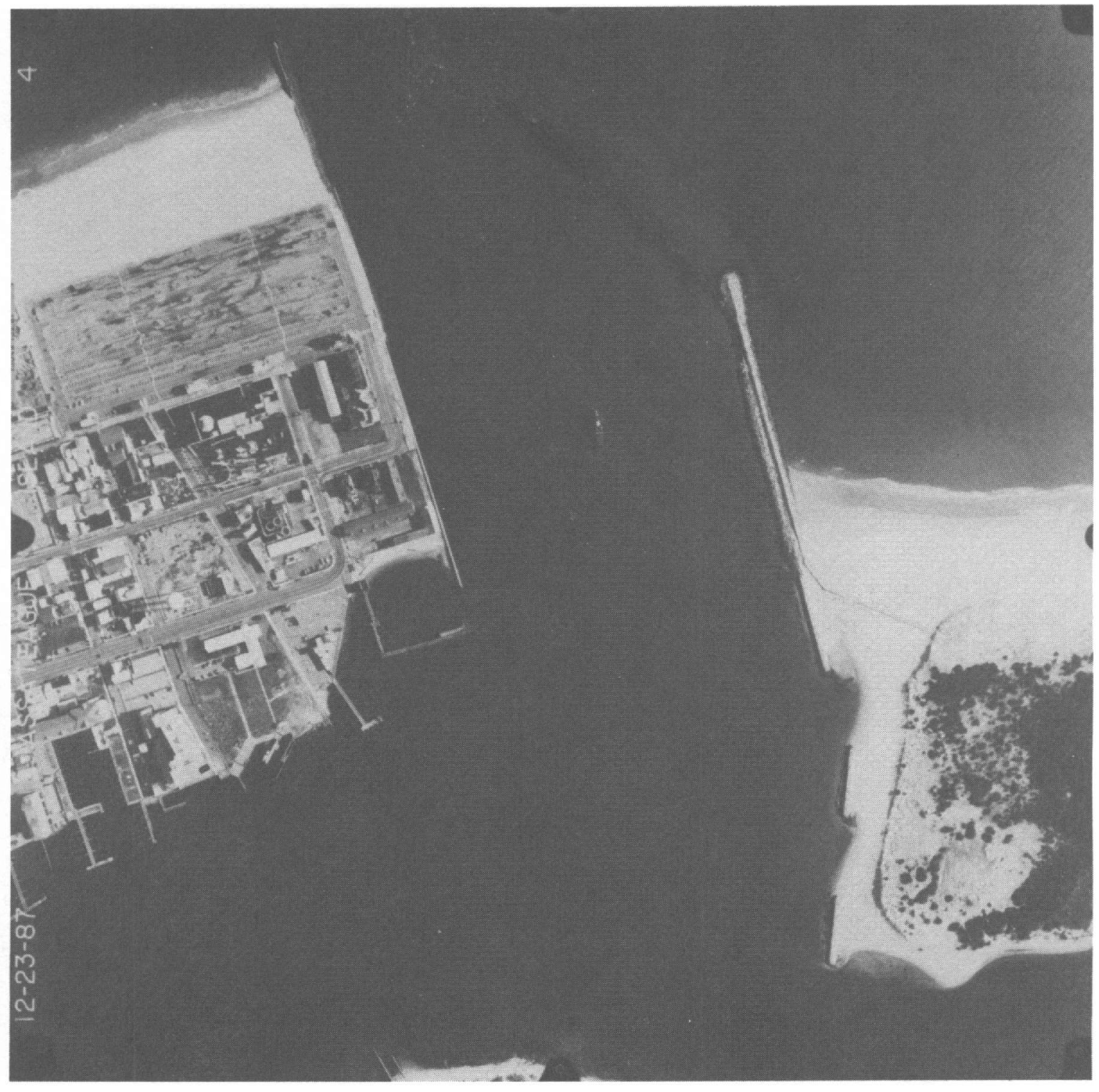

Figure 18. Location of the inlet on 23 December 1987 showing no indication of the reoccurrence of the shoal

next scheduled maintenance dredging in the area to prevent any navigational difficulties with recreational boaters.

\section{Effectiveness of the Rehabilitated Cross Section as a Littoral Barrier}

Assumptions were made during the study that the location of the maximum longshore sand transport rate occurs shoreward of the breaking point for the predominant wave conditions and that the vertical distribution of 


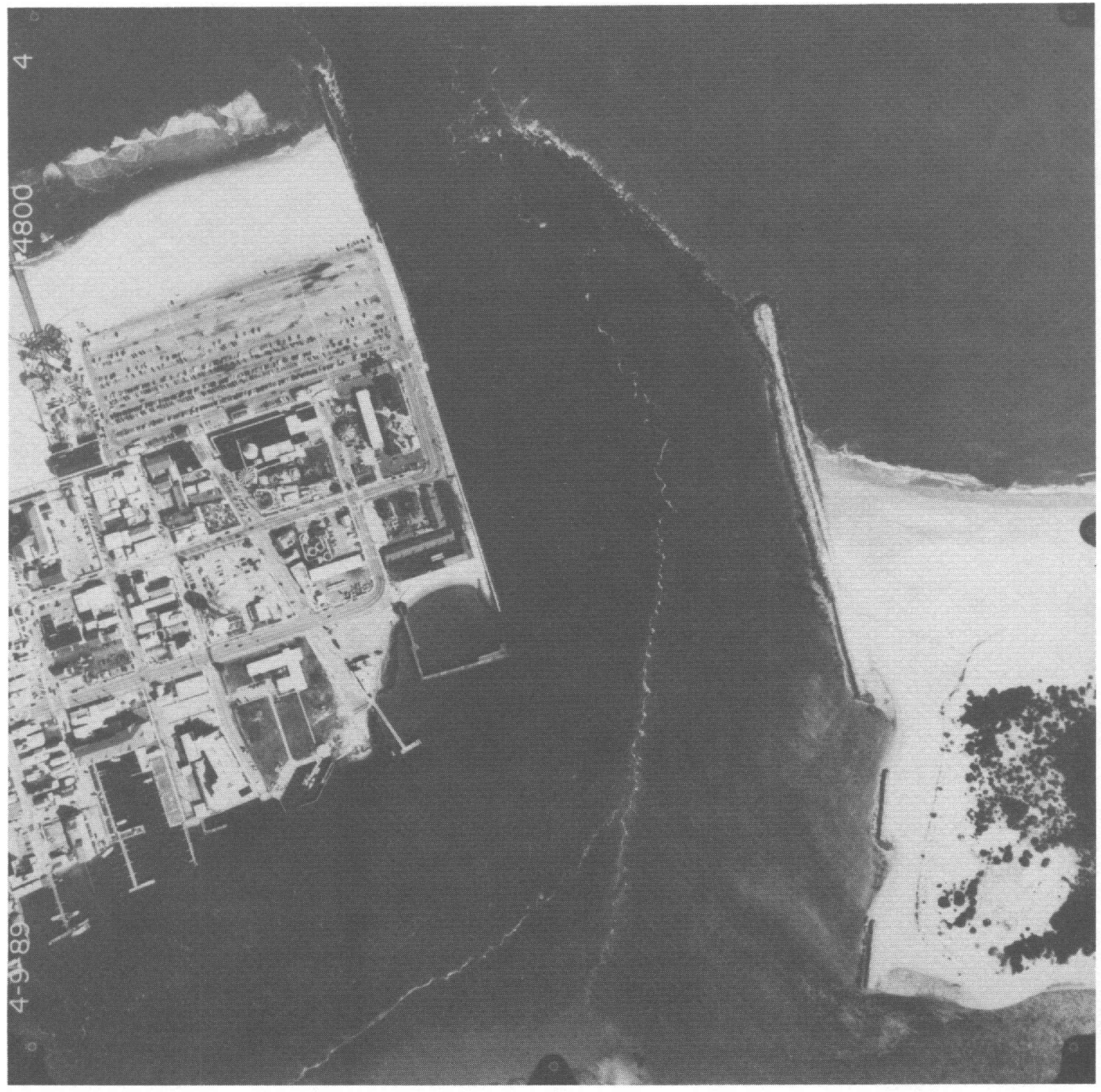

Figure 19. Condition of inlet on 9 April 1989 showing continued erosion of the northwest shoreline

sand transport occurred from the bottom to the spring tide level. These assumptions were considered during the selection of the length and height of the south jetty to be rendered sand-tight and during the design of the precast concrete core wall units to increase the impermeability of the structure.

Shoreline change maps and the postconstruction aerial photography provide significant insight into the effectiveness of the rehabilitated jetty as a littoral barrier. The shoreline change maps (Appendix D) indicate that, following construction of the jetty in 1985, the MHWL shoreline south of the jetty began to migrate oceanward beginning at the jetty and continuing 


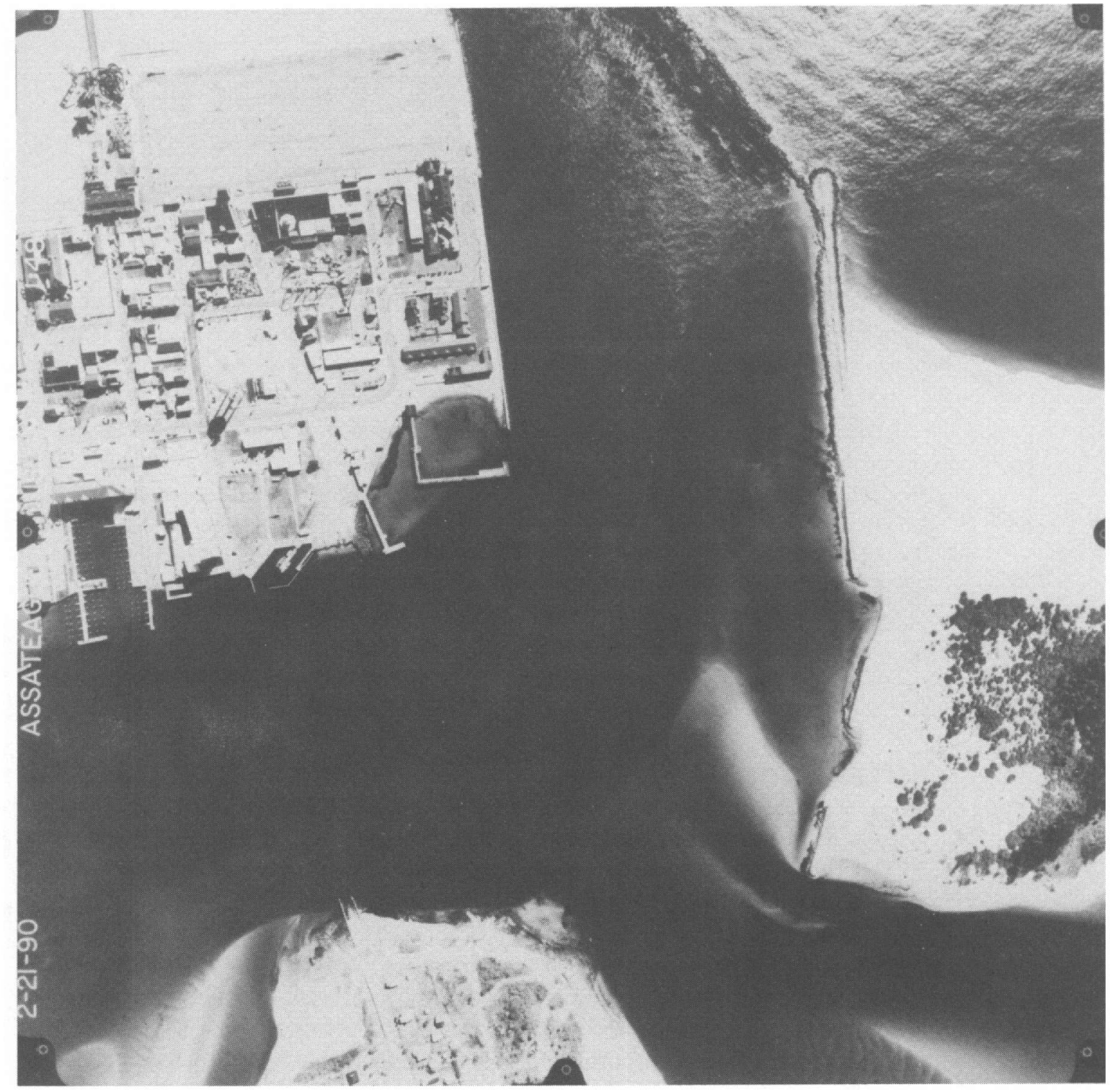

Figure 20. Condition of inlet on 21 February 1990 showing continued erosion of the northwest shoreline

over a distance of $4,000 \mathrm{ft}$ as a result of the sand trapping effectiveness of the jetty.

Dean and Perlin (1977) estimated that the preconstruction transport rate through and over the south jetty was about 45,000 to $60,000 \mathrm{cu}$ yd per year, based on swash measurements at the site during normal wave activity. However, this estimate was qualified as being low since the measurements were not conducted during storm conditions which would be expected to result in higher transport rates. A more realistic range would be about 100,000 to $200,000 \mathrm{cu}$ yd per year. Analysis of the profile data indicates that $1 \mathrm{sq} \mathrm{ft}$ of subaerial beach change is equivalent to about $1 \mathrm{cu}$ yd of sand for this area. This produces an overall estimated accretion of 
about 558,000 cu yd between August 1986 and March 1990, or about $160,000 \mathrm{cu}$ yd per year. This would indicate that a very high percentage of the northward drift was trapped as a result of the jetty sand tightening.

In addition, the evolution of the crenulate bays between the breakwater segments is an indication of the performance of the jetty as a littoral barrier. As discussed by Dean and Perlin (1977), the evolution of the embayments is dependent on the supply of sand reaching them as illustrated in Figure 21. Analysis of the shoreline change map and the aerial photography indicates that the embayments between the breakwaters on Assateague Island are characteristic of the condition of minimal or no longshore sediment transport.

Based on the above evidence, the jetty has been functioning as an efficient littoral barrier. However, the most recent site visit (6-7 March 1990) indicated that the elevation of accretion immediately south of the jetty has increased significantly following construction. This change in elevation is illustrated at various locations along the south side of the jetty in Figures 22, 23, and 24. The photographs presented in Figure 25 indicate that sediment transport is likely to occur over the south jetty due to wind. No signs of sediment transport through the jetty were visible.

\section{Effectiveness of the Shoreline Stabilization on the Northern Shoreline of Assateague Island}

Preconstruction studies assumed that the proposed rehabilitation project would eliminate or significantly reduce the sand supply through and over the south jetty, and the north shoreline of Assateague Island would progressively reorient to an angle of 40 to $50 \mathrm{deg}$ with respect to the south jetty (i.e., parallel to incident wave crests). The rate of the progression was estimated to depend on the quantity of sand that was nourishing the shoreline from the south jetty area prior to rehabilitation. The assumption was that, if the present quantity of sand transported through and over the south jetty over a year period was eliminated, the north shoreline of Assateague Island would start to reorient through the erosion of about the same quantity of sand composing that shoreline.

As discussed previously, Dean and Perlin (1977) estimated that the preconstruction sediment transport rate through and over the south jetty during normal wave conditions ranged from about 45,000 to $60,000 \mathrm{cu}$ yd per year. However, a more realistic range of 100,000 to $200,000 \mathrm{cu}$ yd would be expected when considering storm conditions. As a result, rapid erosion and reorientation of the shoreline would be expected if the transport of this sediment to the shoreline was interrupted. This erosion would continue along the shoreline until the assumed "equilibrium" orientation of about 40 to $50 \mathrm{deg}$ with the south jetty was achieved. As a result, the inshore end of the jetty would be flanked and the entire width of the 


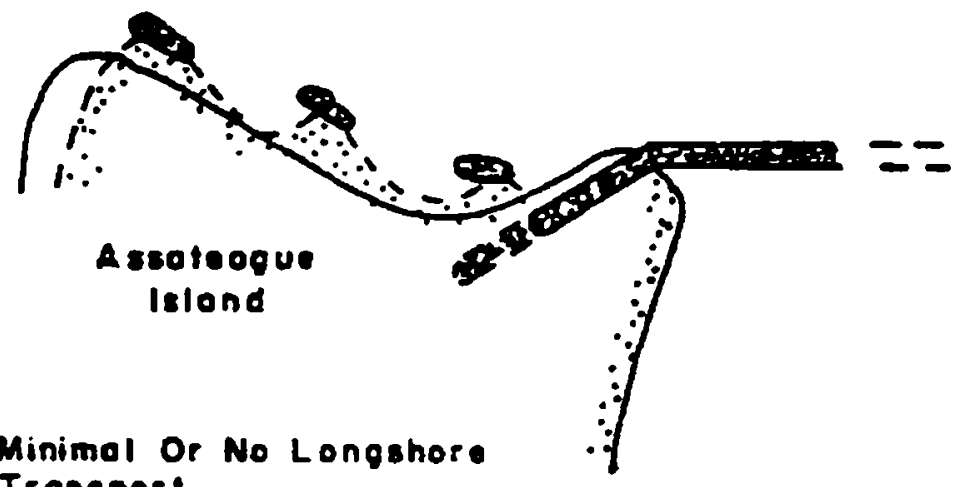

(a) Minimal Or

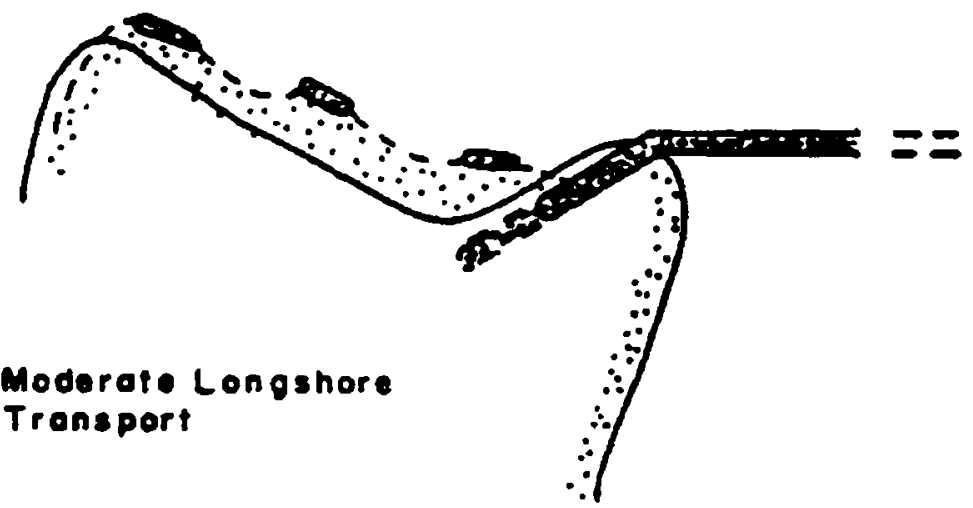

(b) Moderate Longshore Transport

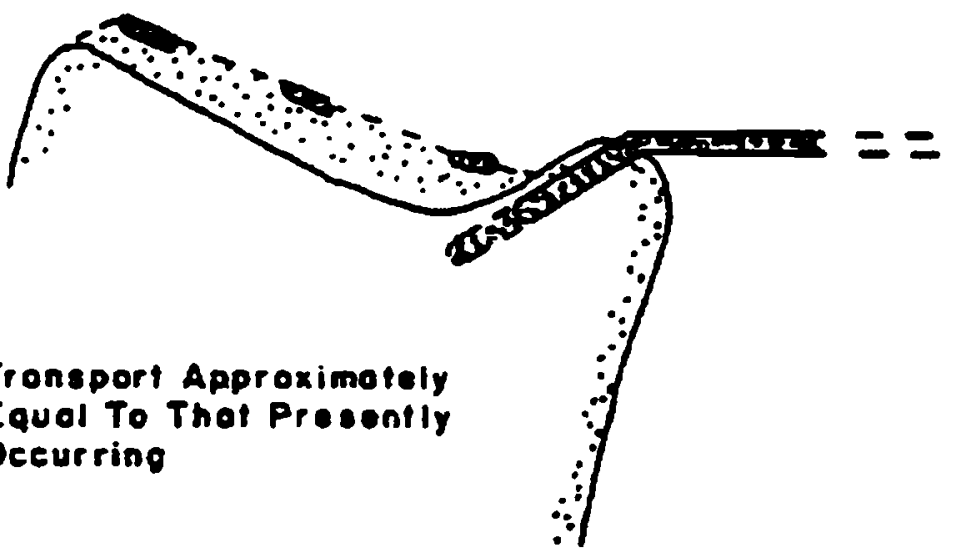

Figure 21. Evolution of the crenulate bays between the breakwater segments 


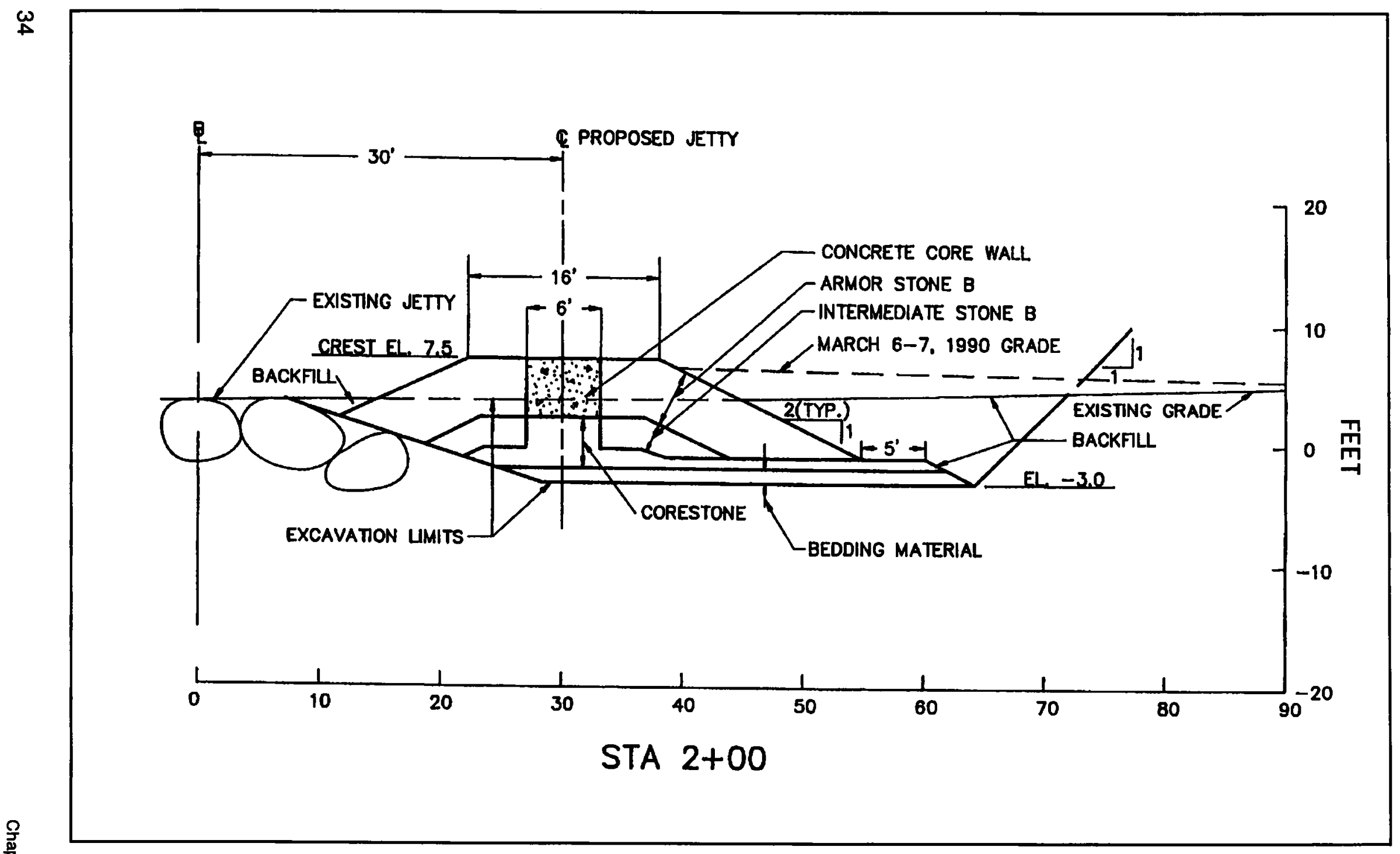

Figure 22. Sand accretion and the associated increase in elevation south of the jetty at sta $2+00$ 


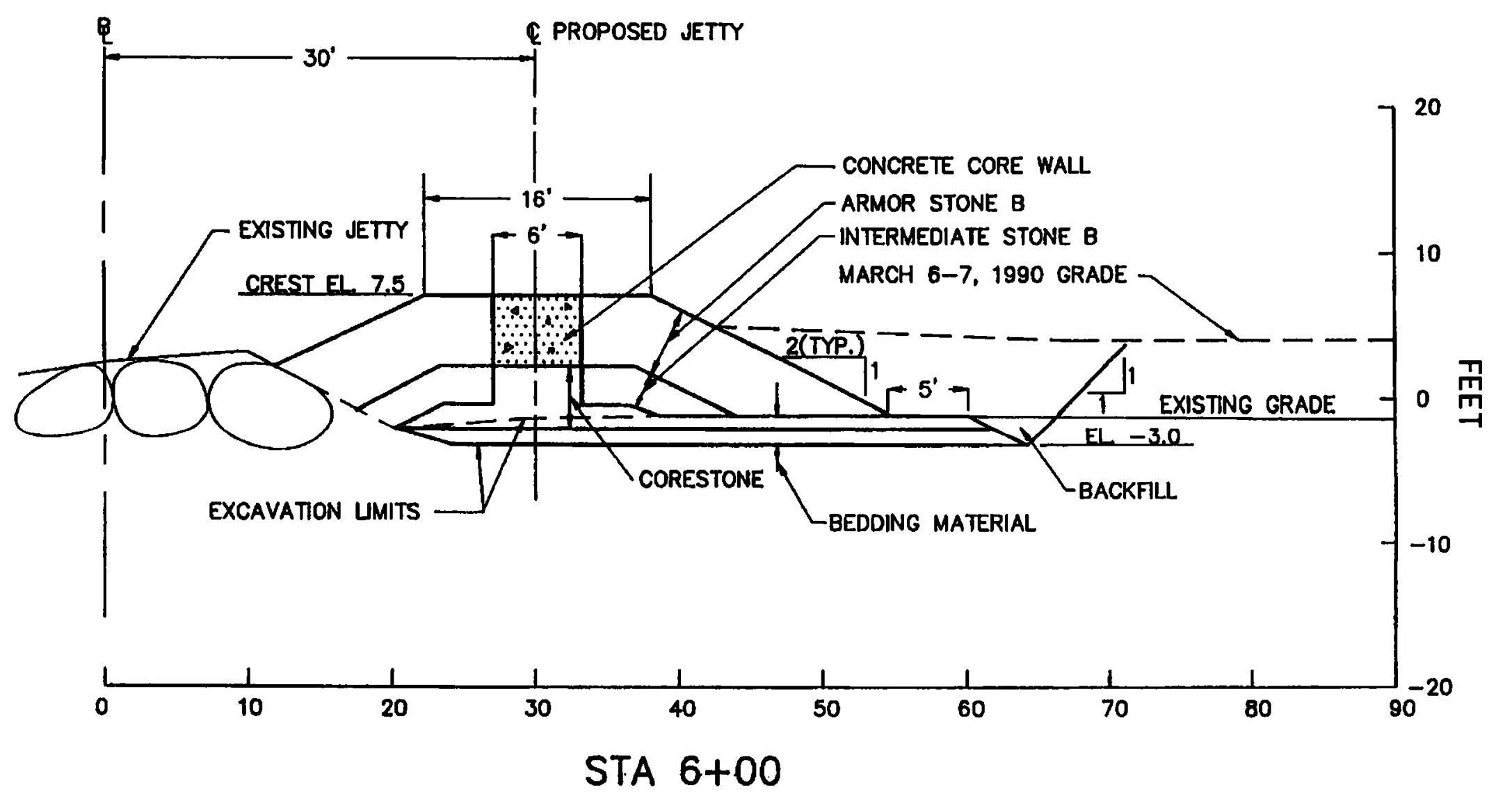

$\mathcal{G}$ Figure 23. Cross-section of sand accretion and the associated increase in elevation immediately south of the jetty at sta $6+00$ 


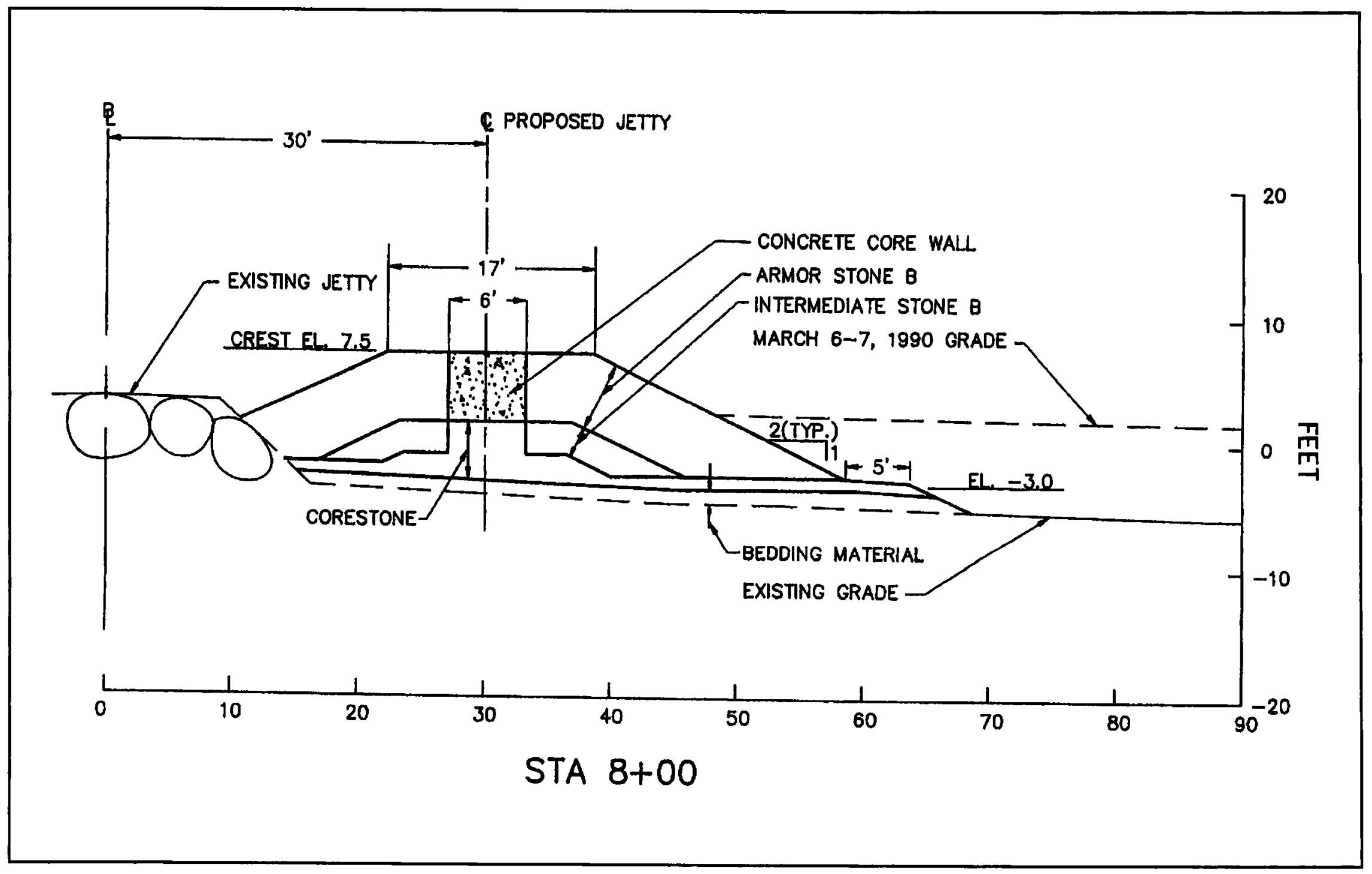

Figure 24. Cross-section of sand accretion and the associated increase in elevation immediately south of the jetty at sta 8+00 


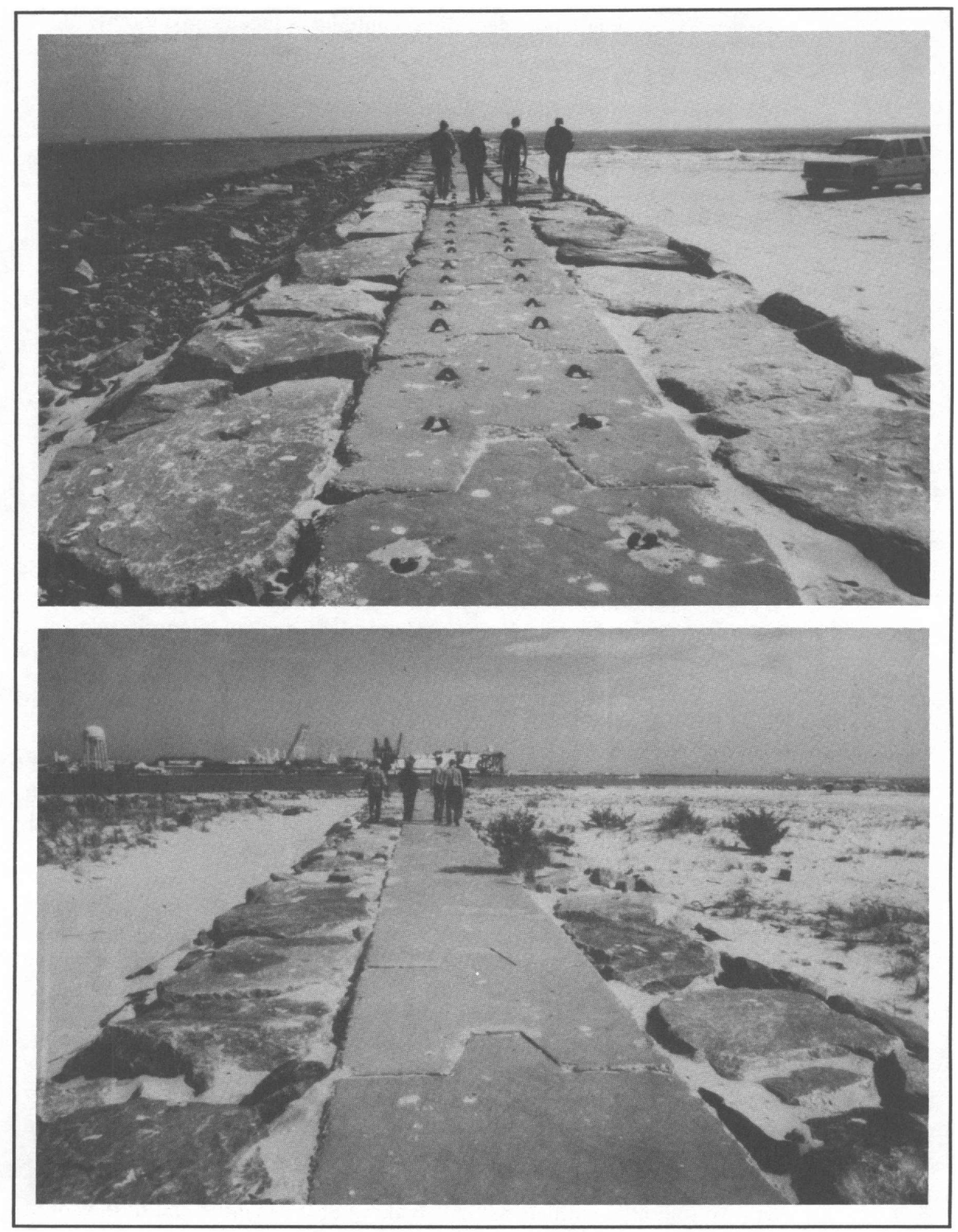

Figure 25. Photographs showing wind-blown sand deposited on top of the south jetty 
northern Assateague Island shoreline would be reduced considerably, thereby creating the possibility of a breach from the ocean side.

To prevent this, the project shoreline was subdivided into a series of littoral cells through the construction of a series of shore-parallel headland breakwaters as the selected approach for shoreline stabilization. Primarily by diffraction, these structures would force the local wave climate to become reoriented by adjusting the angle of oncoming wave crests to the shoreline. For the study area, it was assumed that the rehabilitation would essentially eliminate the sand supply to the north shoreline of Assateague Island, and the shoreline segments between the structures would adjust so that the angle between the wave crests and the shoreline segments would approach zero. This situation would drastically reduce longshore transport along that shoreline and produce stable conditions in the area.

The curvature of coastlines situated between successive headlands has been studied by many investigators. Lewis (1938) and Davies (1958) discussed the theory that refraction of the predominant waves in a coastal area controls the shape and orientation of the area's beaches. Yasso (1965) studied the beach planforms resulting between headlands and found that these planforms fit very closely to the form of a logarithmic spiral curve. Later investigations by Silvester (1970) and Silvester and Ho (1972) supported the description of these planforms by a logarithmic spiral. The results of the last two investigations pointed out that the indentation of the bay from the headland alignment depends on the obliquity of the most persistent waves to this alignment and the amount of sediment available for transport through the embayment. Silvester and Ho (1972) considered that a true equilibrium has been reached along the embayment shoreline when little or no sediment transport is taking place, as the incoming waves have been refracted and diffracted into the area such that simultaneous breaking occurs around the periphery of the bay.

Based on physical model results, Figure 26, developed by Silvester and Ho (1972), indicates the relationship between the ratio of shoreline recession $a$ and the spacing between headlands $b$ versus various angles of wave obliquity for the equilibrium condition (i.e., $a_{b}=0$ or no sand supply).

Using this data, Figure 27, developed during preconstruction studies, indicates the direct relationship between $a$ and $b$ for various angles of wave obliquity. By using the dominant angle of wave obliquity of about $49 \mathrm{deg}$ determined earlier for the northern shoreline of Assateague Island, several combinations of $a$ and $b$ were evaluated. The primary controlling factor in this evaluation was the limit of the equilibrium shoreline recession that could be tolerated without risking flanking of the inshore end of the south jetty. As a result of this evaluation, an alternative was selected using three headland breakwaters along the shoreline.

The predicted equilibrium shoreline resulting for this alternative is shown in Figure 27 along with the preconstruction mean high water shoreline. The mean high water shorelines from each of the aerial photographs 


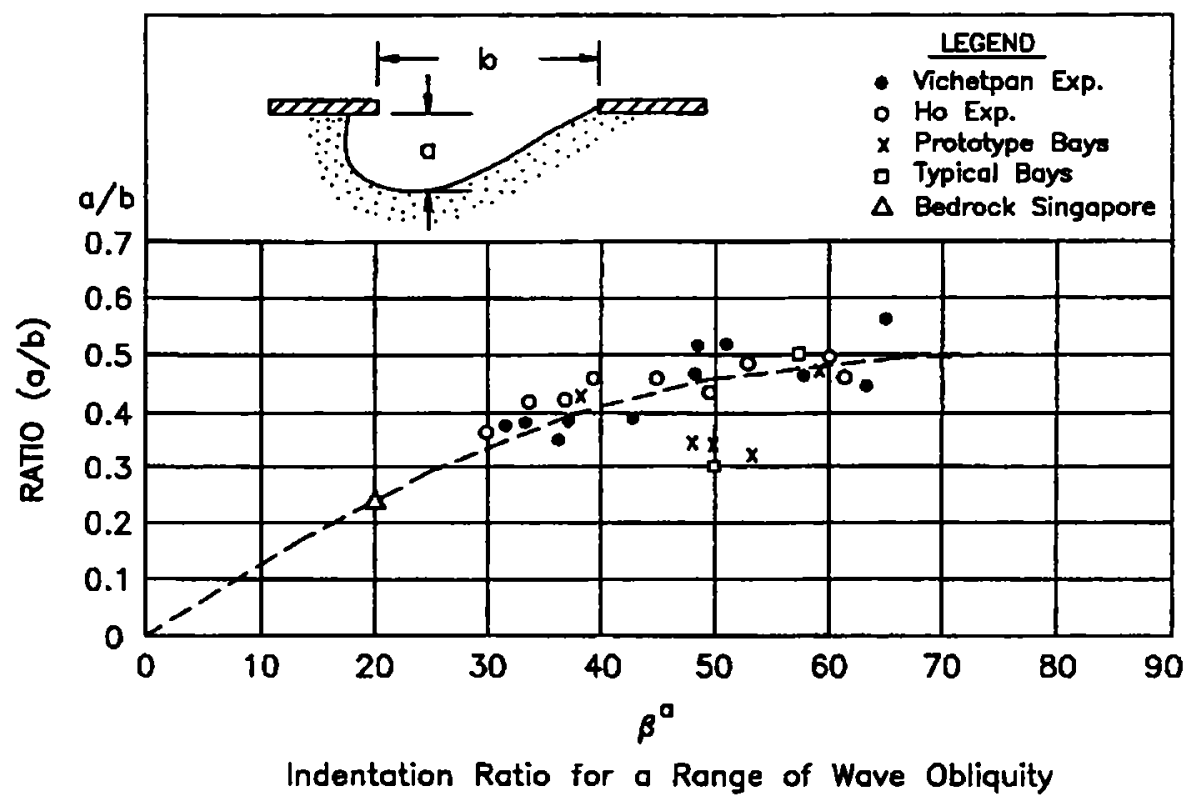

Figure 26. Results from physical model developed by Silvester and Ho (1972)

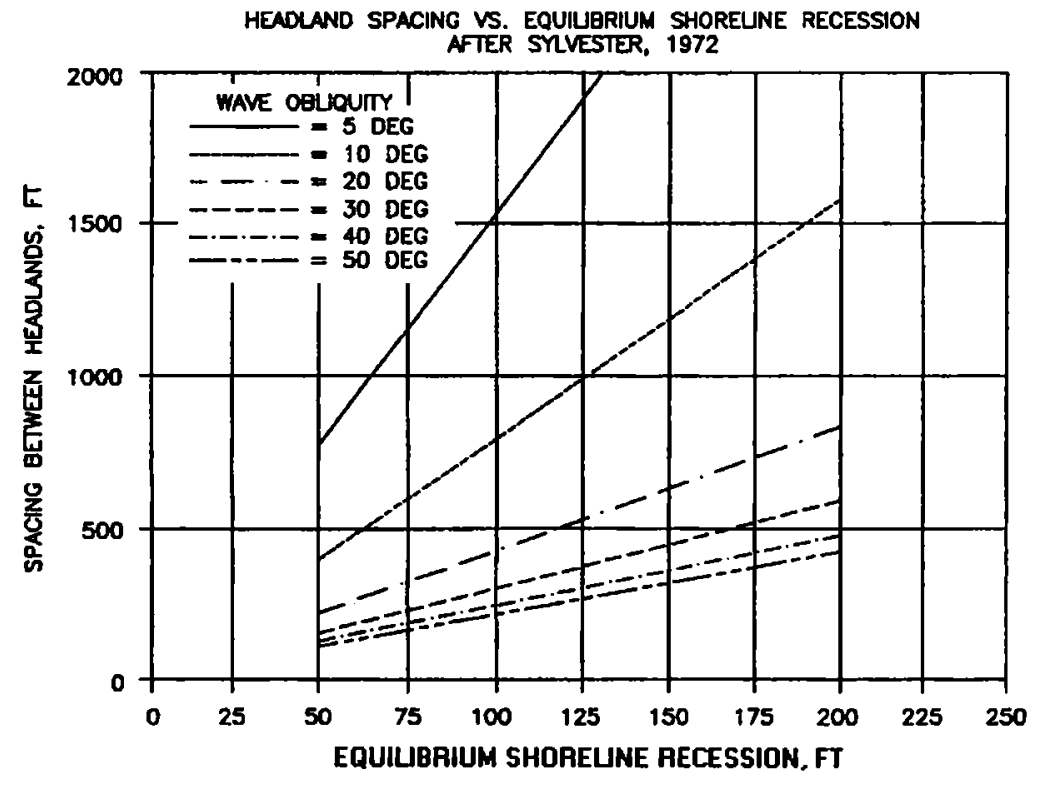

Figure 27. Relationship between $a$ and $b$ for various angles of wave obliquity 
are also shown in Figure 28. Analysis of Figure 28 indicates that following construction of the jetty and the headland breakwaters, the shoreline segments between the breakwaters began to evolve towards the predicted shoreline planform. For the shoreline segment between Breakwaters No. 1 and No. 2, the most significant movement occurred by December 1987 followed by some wobbling of the planform back and forth until reaching the position shown in the March 1990 survey. The shoreline segment between Breakwaters No. 2 and No. 3 shows a progressive evolution towards the predicted shoreline.

Analysis of Figure 28 indicates that neither of the crenulate bays between the breakwaters has reached the predicted shoreline position, particularly the embayment shoreline between Breakwaters No. 2 and No. 3 . The back and forth movement of the embayment shorelines between Breakwaters No. 1 and No. 2, while maintaining a relatively constant degree of curvature, suggests that this embayment may have reached equilibrium. Although somewhat of a similar trend appears in the embayment between Breakwaters No. 2 and No. 3, the location of the latest shoreline, March 1990, suggests that this shoreline may not have reached equilibrium yet.

The equilibrium in either of the embayments would be expected to be a "dynamic equilibrium" subject to some fluctuation due to variations in the wave conditions and sediment transport reaching the locations. Overall, the headland breakwaters appear to be effectively stabilizing the northern shoreline of Assateague Island as evident from the shoreline position map (Figure 28).

Regarding the predicted shoreline position using the technique developed by Silvester and Ho (1972), the general shape of the actual embayments is relatively similar to the predicted shapes, although the degree of indentation is somewhat less than predicted in both cases. Sediment transport processes at this site are not totally dominated by wave conditions as assumed by the prediction technique. Dean and Perlin (1977) demonstrated that tidal currents significantly contribute to the sediment transport processes at the northern end of Assateague Island. The combined effects of tidal currents and variations in wave conditions acting on each embayment versus the constant wave angle of obliquity may explain the less than predicted crenulate shapes of the embayments. However, the overall prediction represented the actual observed behavior reasonably well. This is particularly true since the embayment between Breakwaters No. 2 and No. 3 appears not to have reached equilibrium. 


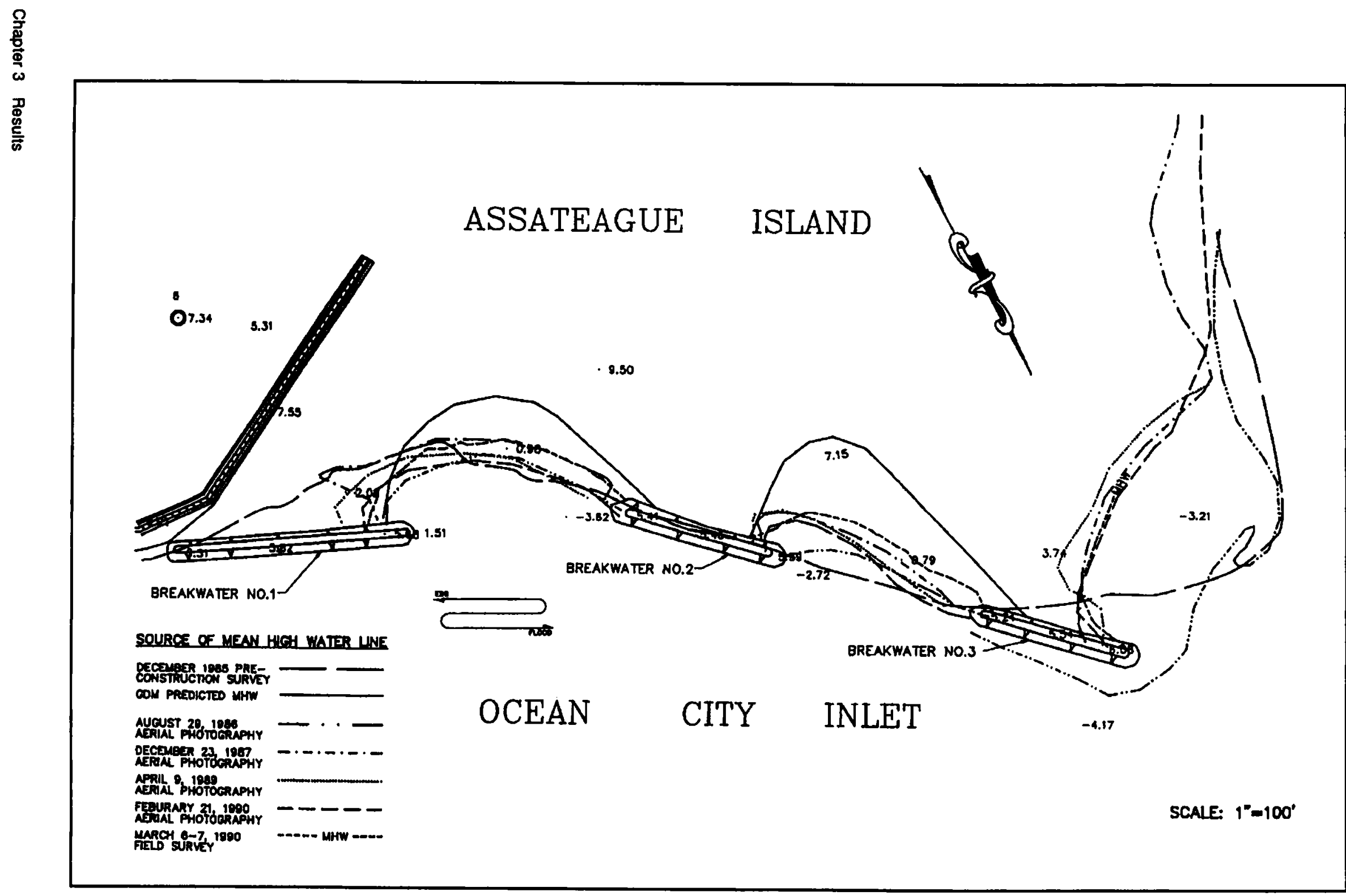

$\pm \quad$ Figure 28. Migration of shoreline segments between breakwaters 


\section{Consideration of the Shore Protection Manual Longshore Transport Formula}

The fundamental formula for calculating the longshore sediment transport rate is

$$
Q=K P l_{s}
$$

where

$$
\begin{aligned}
Q & =\text { longshore sand transport rate } \\
K & =\text { empirical coefficient } \\
P l_{s} & =\text { longshore energy flux factor }
\end{aligned}
$$

The empirical coefficient $K$ is determined by measuring the quantity of sand transported during a given time period and comparing that value to the value of $P l_{s}$ calculated from the wave conditions existing during the same time period (i.e., $K=P l_{s} / Q$ ). The value of $K$ has varied significantly throughout recent years and is based largely on data from the Pacific Coast. Determination of the $K$ value for use at a particular site, in this case an Atlantic Coast site, was an objective of the monitoring program. Measuring the amount of sand accumulated at the rehabilitated south jetty, and comparing this sediment quantity to the value of longshore wave energy flux would result in an additional determination of the empirical coefficient. This value was then to be compared with the value presented in the Shore Protection Manual (SPM) for further verification of the SPM formula.

A qualitative approach consisting of the development of an estimate of the annual longshore wave energy flux from the Wave Information Studies (WIS) data hindcasted for the area from 1956 to 1976 was considered. However, field observations and analysis of the aerial photography indicated that the complex offshore bathymetry resulted in significant nearshore wave refraction and diffraction. These effects could not be accounted for when transforming the WIS data to the site. Due to these problems, neither a quantitative nor a qualitative evaluation of the SPM transport formula could be accomplished.

\section{Distribution of Longshore Sand Transport Across the Surf Zone}

No verified methodology is available to determine the distribution of longshore sand transport across the surf zone. A knowledge of this distribution could be useful in developing a functional design procedure to determine the length and height of jetties and groins. For example, the 
ability to define the location of the maximum longshore transport rate across the surf zone would allow the selection of the structure length to be made to achieve the desired degree of effectiveness of trapping littoral drift.

Bijker (1971), Komar (1977), Sawaragi and Deguchi (1978), and Thornton (1973) have investigated the distribution of longshore transport across the surf zone. The majority of these investigations attempted to obtain an actual measured distribution from physical model and/or field studies to test analytical techniques of predicting the distribution. The technique used, placement of bed load sand traps across the surf zone, generally met with limited success.

More recent investigations by Fulford (1982), Berek and Dean (1982), and Bodge and Dean (1987) concentrated on obtaining the longshore distribution of sediment transport across the surf zone by measuring the updrift accretion at a total littoral barrier in both the offshore and alongshore directions.

Their approach used the updrift sand accretion at a total littoral barrier across the surf zone, such as a long groin or a jetty. In order to obtain a reasonably accurate distribution, at least two criteria must be satisfied:

a. The structure must be a total barrier to longshore transport, both for transport through and over the structure, and around the outside end of the structure.

b. No onshore/offshore transport should be occurring, i.e., the beach profiles should be initially in equilibrium and little offshore transport occurring during the period of measurement.

Assuming these two criteria are met, it is proposed that the measurement of the sediment distribution updrift of a total littoral barrier could be used to represent the distribution of longshore transport across the surf zone. It is considered that at some point, $x_{o}$, updrift of the barrier, the longshore transport rate is fully developed and is not reduced by the effect of the barrier. Between this point and the barrier, the longshore transport is gradually reduced to a value of zero. The sediment transported alongshore is deposited in this zone as the longshore sand transport rate decreases. The rate of deposition is expected to vary inversely with the longshore transport rate with a value of zero at the point $x_{o}$ and increasing to a maximum at the barrier.

Based on results of previous investigations, it is assumed that the maximum longshore transport occurs at some point shoreward of the breaker line and decreases significantly both in the shoreward and offshore directions. Assuming that longshore transport rates decrease as the littoral barrier is approached implies that the sediment being transported would be deposited proportional to the local longshore transport rate. In other words, if the maximum longshore transport is occurring at the midpoint of the surf zone $\left(y / y_{b}=0.5\right)$, then the maximum deposition of sediment 
should also occur at that point at the littoral barrier. The rate of deposition would also be a function of the distance updrift of the barrier as well as the position across the surf zone since it is assumed that the longshore transport rate is a function of this distance.

Incremental measurement of sediment deposition updrift of a total littoral barrier in both the updrift (x) and offshore (y) directions is thus proposed to result in the distribution of the longshore sediment transport rate across the surf zone.

This distribution can be developed as discussed by Fulford (1982) and Bodge and Dean (1987) by measuring the sand trapped by the rehabilitated south jetty. Comparison of this distribution with wave data during the same time period would be useful in the development of functional design criteria for jetties and groins.

For the south jetty project, a grid consisting of cells in the offshore and alongshore direction was placed over the ISRP survey data obtained in July 1986 and January 1989 for Profiles AI-0, AI-T, AI-1, AI-2 and AI-3. Figure 29 illustrates the grid developed. The control volumes created by the grid lines were $100 \mathrm{ft}$ in width in the offshore direction. The length of each control volume was the spacing interval between profiles.

Elevation values were developed at each intersection point of $x$ and $y$ grid lines by interpolation between elevations contained in the ISRP file. The volumetric change in each cell between the 1986 and the 1989 surveys was then calculated by determining the average area change between the surveys for each cell. These data were imported into a Lotus 123 file where the average end areas and the alongshore distance between each profile were used to calculate the volume changes.

Using this procedure, the distribution of the volumetric accretion, which is assumed to represent the distribution of net longshore transport, was computed at distances south of the south jetty corresponding to the surveyed profile locations. Table 3 shows the resulting values of the longshore sediment transport (volumetric accretion) distributions for the incremental distances south of the jetty. The incremental cell volumes shown in Table 3 were divided by the time period between the surveys ( 2.5 years) and plotted as net longshore transport in cubic yards per year in Figure 30.

As expected, a point was reached updrift of the jetty at which the longshore transport rate was fully developed, as evidenced by negligible differences in the maximum longshore transport distribution (accretion) computed at that point versus the previous location. This point occurred about 4,500 $\mathrm{ft}$ updrift of the jetty and coincides with the updrift limit of the accretion fillet as shown in Appendix D. 


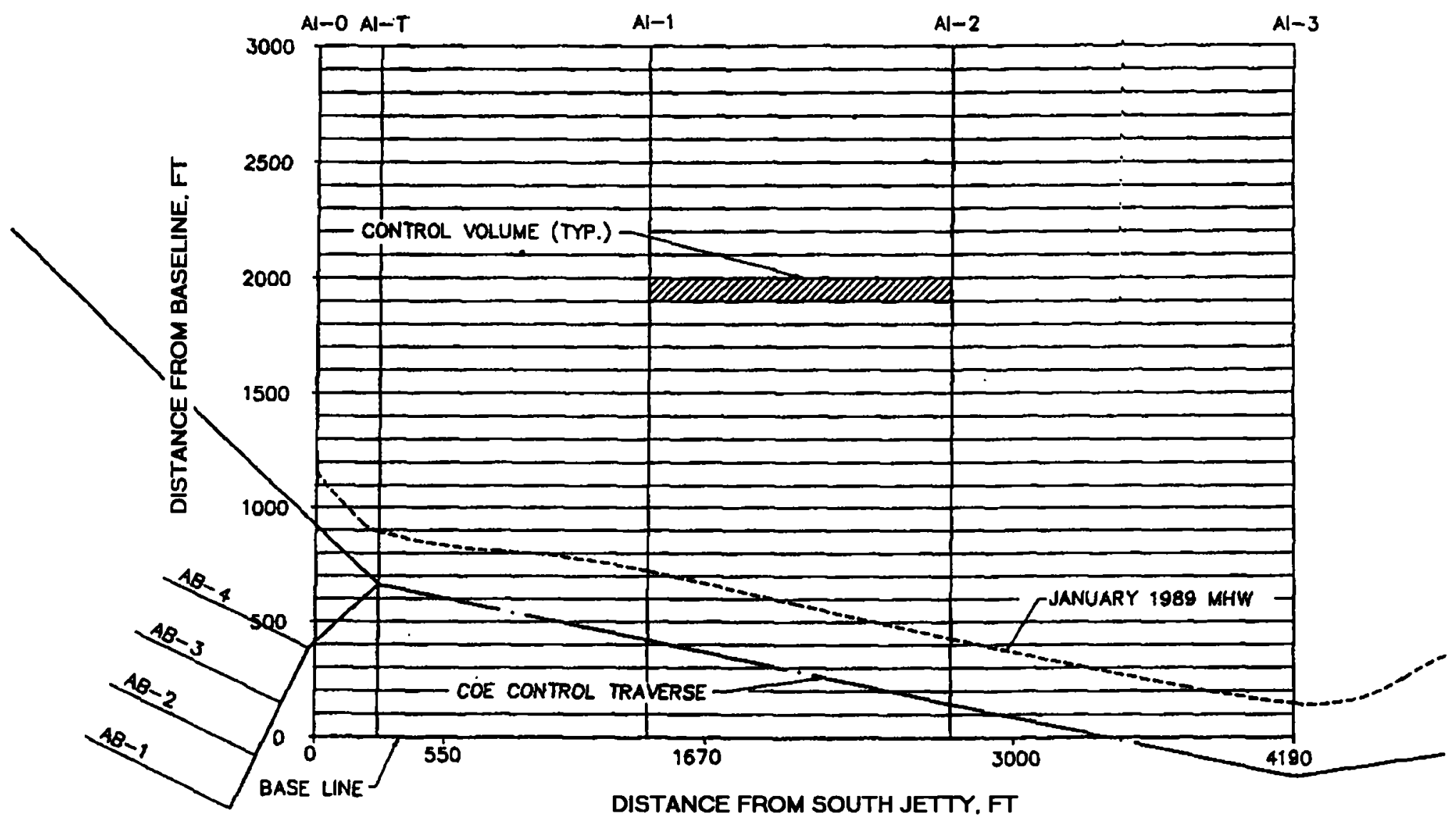

CONTROL VOLUME GRID

जे Figure 29. Grid pattern developed for analysis of the profile data for the south jetty 


\section{Table 3 \\ Distribution of Sediment Transport Average Cell End Area and Volume}

\begin{tabular}{|c|c|c|c|c|c|}
\hline Cell Number & $\begin{array}{l}\text { Distance From } \\
\text { BL, ft }\end{array}$ & $\begin{array}{l}\text { AL-O/Al-T, } \\
\text { cu yd/year }\end{array}$ & $\begin{array}{l}\text { AL-T/Al-1, } \\
\text { cu yd/year }\end{array}$ & $\begin{array}{l}\text { Al-1/Al-2, } \\
\text { cu yd/yoer }\end{array}$ & $\begin{array}{l}\text { Al-2/AI-3, } \\
\text { cu yd/year }\end{array}$ \\
\hline 1 & 50 & 0 & 0 & 856 & 2250 \\
\hline 2 & 150 & 0 & .786 & -1586 & -1429 \\
\hline 3 & 250 & 0 & 2090 & 4903 & 4202 \\
\hline 4 & 350 & 0 & 3015 & 5966 & 2700 \\
\hline 5 & 450 & 0 & 2751 & 10215 & 9343 \\
\hline 6 & 550 & 0 & -921 & -1757 & -6941 \\
\hline 7 & 650 & -227 & 1798 & 2450 & -3070 \\
\hline 8 & 750 & -28 & 7409 & 18605 & 19633 \\
\hline 9 & 850 & -11 & 5460 & 16321 & 20907 \\
\hline 10 & 950 & -424 & 1430 & 9951 & 14348 \\
\hline 11 & 1050 & 132 & -1722 & 5139 & 11778 \\
\hline 12 & 1150 & -197 & -5348 & 1022 & 8606 \\
\hline 13 & 1250 & -633 & -3505 & 1905 & 8242 \\
\hline 14 & 1350 & 44 & -41 & 4644 & 9864 \\
\hline 15 & 1450 & 679 & 2456 & 7973 & 12166 \\
\hline 16 & 1550 & 693 & 2542 & 4764 & 6096 \\
\hline 17 & 1650 & 558 & 1848 & 2320 & 3089 \\
\hline 18 & 1750 & 573 & 1866 & 3877 & 6318 \\
\hline 19 & 1850 & 580 & 2582 & 6732 & 11809 \\
\hline 20 & 1950 & 627 & 2947 & 6137 & 9937 \\
\hline 21 & 2050 & 617 & 2900 & 7546 & 10994 \\
\hline 22 & 2150 & 264 & 1703 & 7158 & 10946 \\
\hline 23 & 2250 & 89 & 595 & 4882 & 8360 \\
\hline 24 & 2350 & 419 & 2327 & 6703 & 10066 \\
\hline 25 & 2450 & 755 & 4386 & 11094 & 16021 \\
\hline 26 & 2550 & 559 & 2669 & 7966 & 13517 \\
\hline 27 & 2650 & 525 & 3402 & 8251 & 12790 \\
\hline 28 & 2750 & 473 & 3854 & 9650 & 14651 \\
\hline 29 & 2850 & 484 & 4147 & 10098 & 15015 \\
\hline 30 & 2950 & 399 & 3579 & 8534 & 13070 \\
\hline \multicolumn{2}{|c|}{$\begin{array}{l}\text { Total Incremental Volume Change, } \\
\text { cu yd }\end{array}$} & 6,950 & 55,430 & 192,321 & 275,276 \\
\hline \multicolumn{2}{|c|}{ Total Net Volume Change, cu yd } & \multicolumn{4}{|l|}{275,276} \\
\hline
\end{tabular}




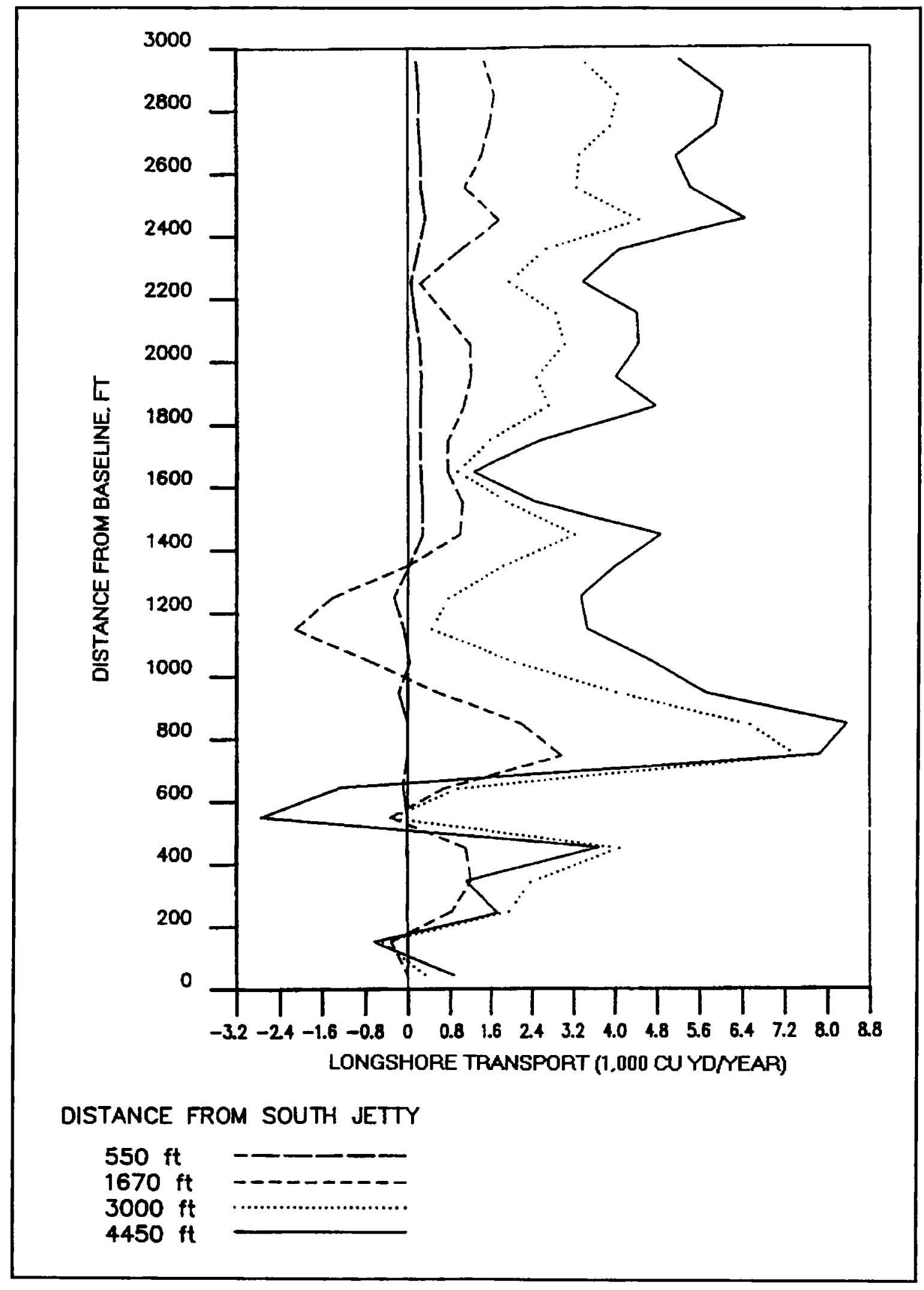

Figure 30. Incremental cell volumes indicating net longshore transport 


\section{Shoreline and Profile Response/ Onshore-Offshore Sand Transport}

Periodic bathymetric surveys, aerial photography, and shoreline change maps were analyzed to determine the effects of the south jetty rehabilitation on the Atlantic Coast shoreline of northern Assateague Island and profile response.

The expected response of the northern Assateague shoreline was migration oceanward for some distance south of the jetty due to the sand trapping effect of the rehabilitated cross-section. Analysis of the 1 in. $=200$ ft shoreline change maps (Appendix D) indicates that significant shoreline changes were limited to $4,000 \mathrm{ft}$ south of the south jetty. Beyond that point, the mean high water shorelines converge and show only minor change in position. Table 4 shows the shoreline changes between surveys along the northern $4,000 \mathrm{ft}$ of shoreline.

The jetty was completed in December 1985 . Only limited survey data were available showing the preconstruction shoreline as shown in Appendix D. Comparison of the preconstruction mean high water shoreline with the first aerial photograph mean high water shoreline, August 1986, indicates an oceanward advancement of the mean high water shoreline of about $200 \mathrm{ft}$ at the jetty and an advancement of about $110 \mathrm{ft}$ at a point about $600 \mathrm{ft}$ south of the jetty. Unfortunately, no further data are available south of that point.

This rapid advancement of the shoreline over the 9-month period following construction was due to the sand trapping ability of the rehabilitated jetty. However, this accretion probably occurred over a longer period since the south jetty began to trap sand as the rehabilitation progressed.

\section{Table 4}

Assateague Island Shoreline Changes From Aerial Photographs

\begin{tabular}{|l|l|l|l|l|l|l|l|l|l|l|l|l|}
\hline & \multicolumn{10}{c|}{ Destance From South Jetty, ft } \\
\cline { 2 - 13 } & 0 & 400 & 800 & 1200 & 1600 & 2000 & 2400 & 2800 & 3200 & 3600 & 4000 & Avg \\
\hline $\begin{array}{l}\text { Aug } 86 \text { to } \\
\text { Dec 87 }\end{array}$ & -200 & -115 & -65 & -10 & 70 & 130 & 110 & 60 & 15 & 10 & -10 & -0.45 \\
\hline $\begin{array}{l}\text { Dec 87 to } \\
\text { Apr 89 }\end{array}$ & 200 & 145 & 115 & 100 & 85 & 100 & 120 & 100 & 90 & 35 & 10 & 100 \\
\hline $\begin{array}{l}\text { Apr } 89 \text { to } \\
\text { Feb 90 }\end{array}$ & 0 & 20 & 15 & 20 & -10 & -30 & -40 & -40 & 25 & 40 & 20 & 1.81 \\
\hline $\begin{array}{l}\text { Feb 90 to } \\
\text { Mar 90 }\end{array}$ & 0 & 20 & 35 & 20 & 45 & 40 & 0 & 40 & 10 & 15 & 20 & 22.2 \\
\hline Average & 0 & 17.5 & 25 & 32.5 & 47.5 & 60 & 47.5 & 40 & 35 & 25 & 10 & \\
\hline
\end{tabular}


Comparison of the August 1986 and the December 1987 mean high water shoreline positions indicates a reversal of the shoreline movement over a distance of about $1,200 \mathrm{ft}$ south of the jetty. The average change over this distance was a recession of about $100 \mathrm{ft}$. This shoreline response was not expected but could have been due to storm events or seasonal effects. Analysis of the offshore wave data collected during that period indicates about 13 storm events with wave heights ranging from 6.5 to $16.0 \mathrm{ft}$. Another reason for this shoreline response is the rapid shoreline accretion following jetty construction reshaping the profiles in that area to the point of dis-equilibrium. Inspection of the profiles at the northern end of the island reveals the rapid accretion and readjustment of profile shape (Appendix C).

From the end of the erosion area $(1,200 \mathrm{ft}$ south of the jetty) to a point about $3,000 \mathrm{ft}$ south of the jetty, a significant advancement of the shoreline is shown, which is relatively equal in area to the erosion area to the north. The average shoreline change over this distance was an oceanward advancement of about $90 \mathrm{ft}$. Estimating that $1 \mathrm{sq} \mathrm{ft}$ of beach change is equivalent to about $1 \mathrm{cu}$ yd of sand results in an overall estimated accretion of about $42,000 \mathrm{cu}$ yd during this period.

Between December 1987 and April 1989, there was a significant seasonal accretion along the entire shoreline from the jetty to a point $4,000 \mathrm{ft}$ south of the jetty. The average advancement was approximately $100 \mathrm{ft}$ and is estimated to be equivalent to an accretion of about $400,000 \mathrm{cu}$ yd of sand. Between April 1989 and February 1990, the mean high water shoreline changes were relatively minor with some areas advancing oceanward and some areas receding landward with the maximum change being about $40 \mathrm{ft}$. At a point about $4,400 \mathrm{ft}$ south of the jetty, both of the shorelines converge. The average change over this distance was about $2 \mathrm{ft}$ of oceanward advancement.

A comparison of the February 1990 aerial photography mean high water shoreline to the March 1990 surveyed mean high water shoreline indicates an average oceanward advancement of about $22 \mathrm{ft}$ during this period. However, due to the short time frame of less than 1 month, it is questionable whether this shoreline change actually occurred. It is probable that the change shown is attributable to the error in the location of the aerial photograph shoreline. As discussed previously, the aerial photographs used in the development of the shoreline change map were not developed to a precise scale using ground truth in the area. This fact, combined with the subjectivity of locating the mean high water shoreline on the photographs, could account for the magnitude of change shown between the two shorelines.

Profiles were surveyed four times during the study period. A total of 15 profiles were surveyed along the Atlantic Ocean shoreline of the island, and 4 profiles were surveyed along the northern end of the island and extending into the inlet (Figure 16). The ocean surveys extended to a water depth of $-36 \mathrm{ft}$ NGVD and were obtained using a Leitz Set 3 total 
station in combination with reflecting prisms and rod or mast. The offshore segment of each profile was surveyed by shooting the total station at two sets of triple prisms mounted atop a 44- $\mathrm{ft}$ mast supported on a steel sea sled. The sled was towed by boat. The survey system provided vertical and horizontal accuracy within $\pm 0.1 \mathrm{ft}$. Comparison plots of all the surveys are presented in Appendix C. The topographic sections of the profiles were surveyed by shooting a single prism mounted on a rod approximately $5 \mathrm{ft}$ in height. The total station automatically acquired $\mathrm{x}, \mathrm{y}$, and $\mathrm{z}$ coordinates of the ground point over which the rod was held.

In general, following rehabilitation of the south jetty, the nearshore section of the profiles nearest the jetty accreted and evolved through an "equilibrium" stage to a "steeper than equilibrium" stage resulting in the onset of offshore sand transport. Moving farther south, the effects of the jetty were less pronounced, and changes in the profile were not as significant.

A review of the profile data shows that profile shapes vary slightly along the northern part of the island. The ebb shoal modifies the wave characteristics and thus influences the beach slopes immediately adjacent to the south jetty. Generally, the profiles are steeper in this area and exhibit an $A$ value of approximately 0.08 , where "A" is the best-fit coefficient satisfying the equation $y=A x^{2 / 3}$. In the equation, $y$ is the bottom elevation and $x$ is the distance from an onshore baseline. The remainder of the shoreline for a total distance of about 5 miles exhibits an $A$ value of approximately 0.17 .

A regression analysis of the data collected at various times throughout the monitoring effort determined the best-fit $A$ value that satisfied the exponential equation given above. Figures 31 and 32 present plots of the variation in $A$ along the shoreline as determined by the survey data collected. Figure 31 shows a plot of $A$ along the Assateague Island shoreline as determined by a fit to beach profile data between elevation 0.0 and $-15.0 \mathrm{ft}$ NGVD. This range of elevations would be subject to short-term changes in beach profile shape. Figure 32 presents $A$ values found by only fitting the exponential curve between elevation 0.0 and $-25.0 \mathrm{ft}$ NGVD. This figure is considered representative of the range of depths over which sediment moves including sediment movement during extreme storm conditions. In Figure 32, the best-fit of $A$ between 0.0 and $-15.0 \mathrm{ft}$ NGVD of each profile shows larger variability than in Figure 31 . This could be attributed to the shallower water depths responding on a more short-term basis to changing weather conditions. However, all the profiles seem to exhibit a fluctuating $A$ value which is probably due to the changes associated with the onshore/offshore transport of the beach material. The effects of the ebb shoal and the south jetty are pronounced on the profiles, as shown by Figures 31 and 32 . It should be noted, however, that the computed $A$ values for the first two profiles of the January 1989 survey are biased on the high side due to the fact that this data set did not extend as far seaward as the other surveys. If it had, it is anticipated that these profiles would exhibit an $A$ value more closely resembling the other data sets. 


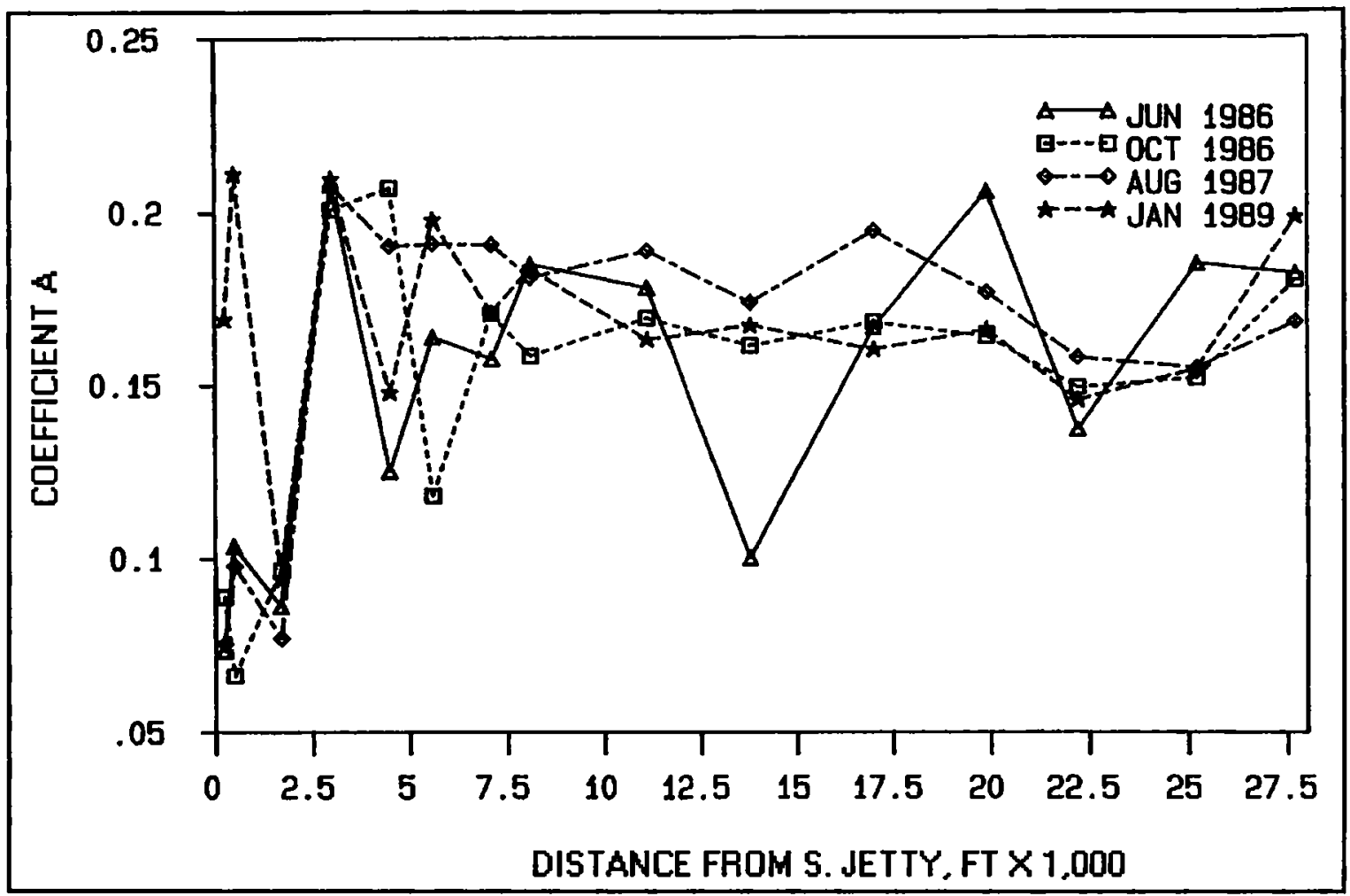

Figure 31. Variation in beach profile coefficient $A$ along the coast of northern Assateague Island: depth 0 to $-15 \mathrm{ft}$ NGVD

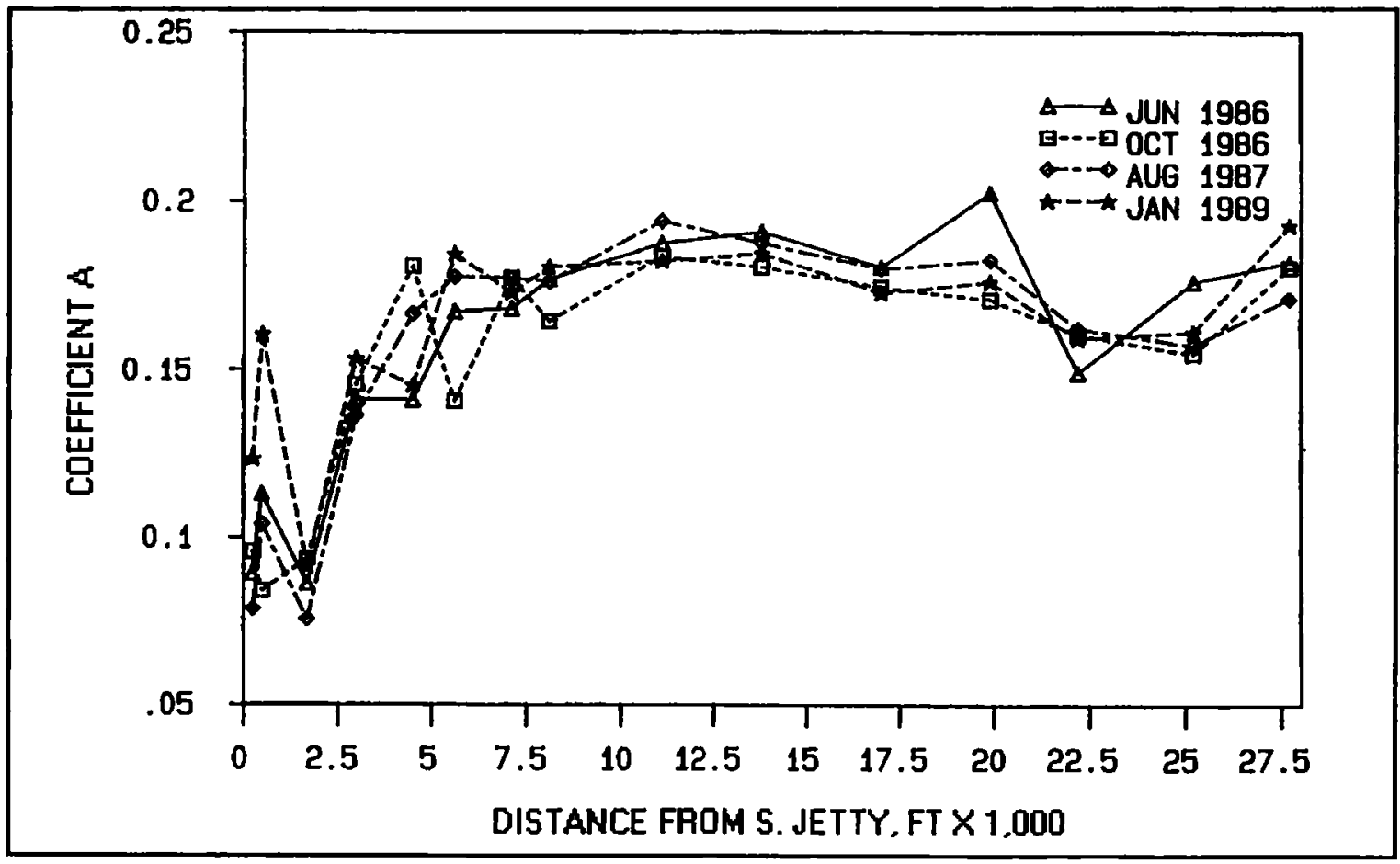

Figure 32. Variation in beach profile coefficient $A$ along the coast of northern Assateague Island: depth 0 to $-25 \mathrm{ft}$ NGVD 


\section{Ebb Shoal Equilibrium and Northern Assateague Island Growth}

Tidal inlets represent an interruption to the continuity of beach processes along the coast. Depending upon local coastal conditions, sediment accumulation in the inlet may occur both landward (flood-tidal delta) and seaward (ebb-tidal delta) of the inlet throat.

Since 1935, erosional rates as high as $33.0 \mathrm{ft} /$ year have been documented (Leatherman 1979) for the northern 8.0 miles of Assateague Island. Sediment normally transported south from Ocean City is moved offshore by the inlet ebb jet and trapped in the ebb-tidal delta sink. Downdrift of the ebb delta, the littoral system is consequently undernourished resulting in high erosion rates.

In the past, investigations of erosional rates for northern Assateague Island have either failed to account for or dismissed any sort of natural bypassing of sediment around the ebb delta to the island itself. Underwood and Anders (1989) evaluated the potential for natural sediment bypassing to northern Assateague Island by examining both recent and historical ebb shoal bathymetric data (1937-1988). Since the 1988 ebb shoal bathymetry, an August 1990 bathymetric survey was completed for the same area. Shoal evolution was then compared with recent shoreline change information for northern Assateague Island from 1849 to 1984. Development of the ebb shoal (last 50 years), provides necessary background information for sediment budget estimates for northern Assateague Island.

Nine bathymetric charts $(1937,1961,1967,1976,1981,1983,1986$, 1988 , and 1990) were used for detailing ebb shoal morphology growth and development. The 1937 and 1981-1990 charts at a scale of 1:200 were constructed based on surveys by the Corps' Baltimore District. National Ocean Survey (NOS) charts at a scale of 1:20,000 for 1961 and 1967 were used, along with a 1976 ebb shoal map at a scale of 1:200 supplied by the University of Delaware. Each data set was hand contoured at 5.0-ft intervals, except for 1961 and 1967 surveys contoured at 6.0-ft intervals. Contours were digitized and input into a surface modeling and analysis system (Contour Plotting System (CPS) 3, Radian Corporation). Each data set was displayed and examined for complete overlap of bathymetric contours, ensuring coverage of the ebb shoal for subsequent volume comparisons. An octagonal polygon with a full area of 3.3 sq miles was digitized around the 1990 data set. The 1990 data set represents the latest bathymetric survey providing complete coverage of the ebb shoal. Each data set was assigned an equivalent bathymetric grid for computing volume differences within this region from 1937 to 1990 . Cumulative ebb shoal volume and rate of change per year were calculated to evaluate shoal growth.

Cumulative volumes for the ebb-tidal delta (1937 through 1990) are depicted in Figure 33. Ebb shoal volume exhibited a net increase until the early 1960 's, then rapidly rose until the late 1960 's or early to mid 1970 's. 


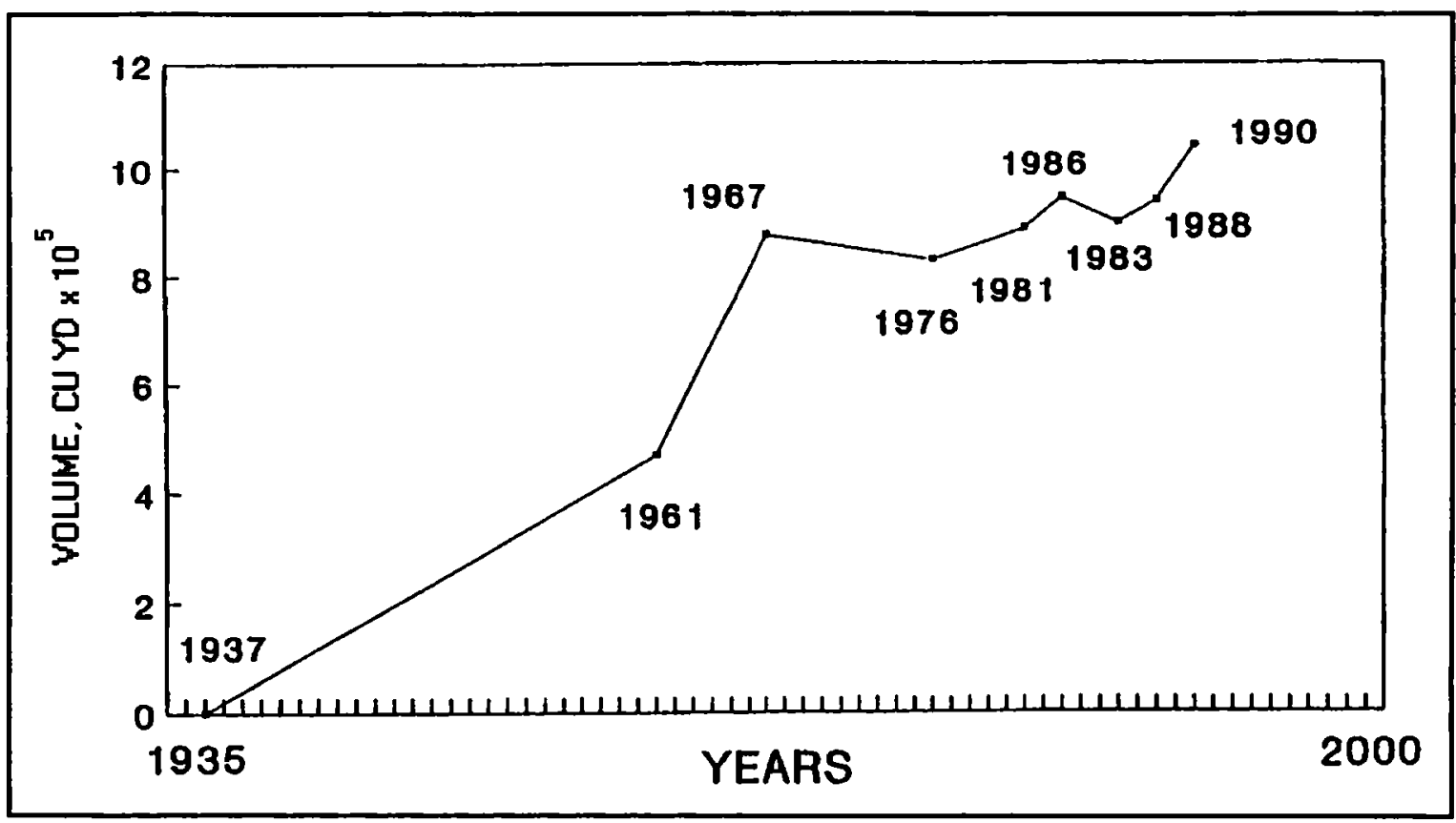

Figure 33. Cumulative volume for the ebb-tidal delta from 1937 through 1990

The rapid rate of growth exhibited between 1961 and 1967 could be a result of sediment now totally bypassing the north jetty fillet. Dean and Perlin (1977), state: "the north jetty is impounded to capacity" and that "in the period 1934-1947, an average of 76 percent of the net material arriving at the north jetty would be bypassed." The rate of shoal volume change per year measured in the present study between 1937-1967 was approximately $353,000 \mathrm{cu}$ yd/year. Since 1967, the rate of growth has decreased to approximately $39,000 \mathrm{cu} \mathrm{yd} /$ year (Figure 34). From 1967-1990, ebb shoal volume has both increased and decreased (Figure 35). This irregular behavior may reflect an approach to a dynamic equilibrium condition where the ebb shoal, which previously acted as a sediment sink, is now allowing sediment to move around to northern Assateague Island shoreline. Presently, Ocean City's inlet ebb shoal extends approximately $3,300 \mathrm{ft}$ offshore, and is approximately $10,500 \mathrm{ft}$ wide.

The state of Maryland nourished Ocean City beach with 2 million cu yd of sand during the summer of 1988 . Preliminary volume results show a 1990 shoal size of 10.4 million cu yd compared with a prenourishment 1988 shoal size of 9.38 million cu yd. The shoal is crescentic shaped and offset to the south.

Knowles (1985) determined Assateague Island's northern shoreline change rates between 1849 and 1984 using historical maps and profile survey data (Figure 36). The study area extended from the inlet southward for approximately $26,200 \mathrm{ft}$. From the early 1930's to the mid 1960's, the average rate of shoreline erosion reached a maximum of $26.9 \mathrm{ft} /$ year. This accelerated erosion rate corresponded with the stabilization of Ocean City's inlet in 1935. Profile survey data between 1962 and 1984 show averaged erosional rates have decreased to $6.6 \mathrm{ft} / \mathrm{year}$. 


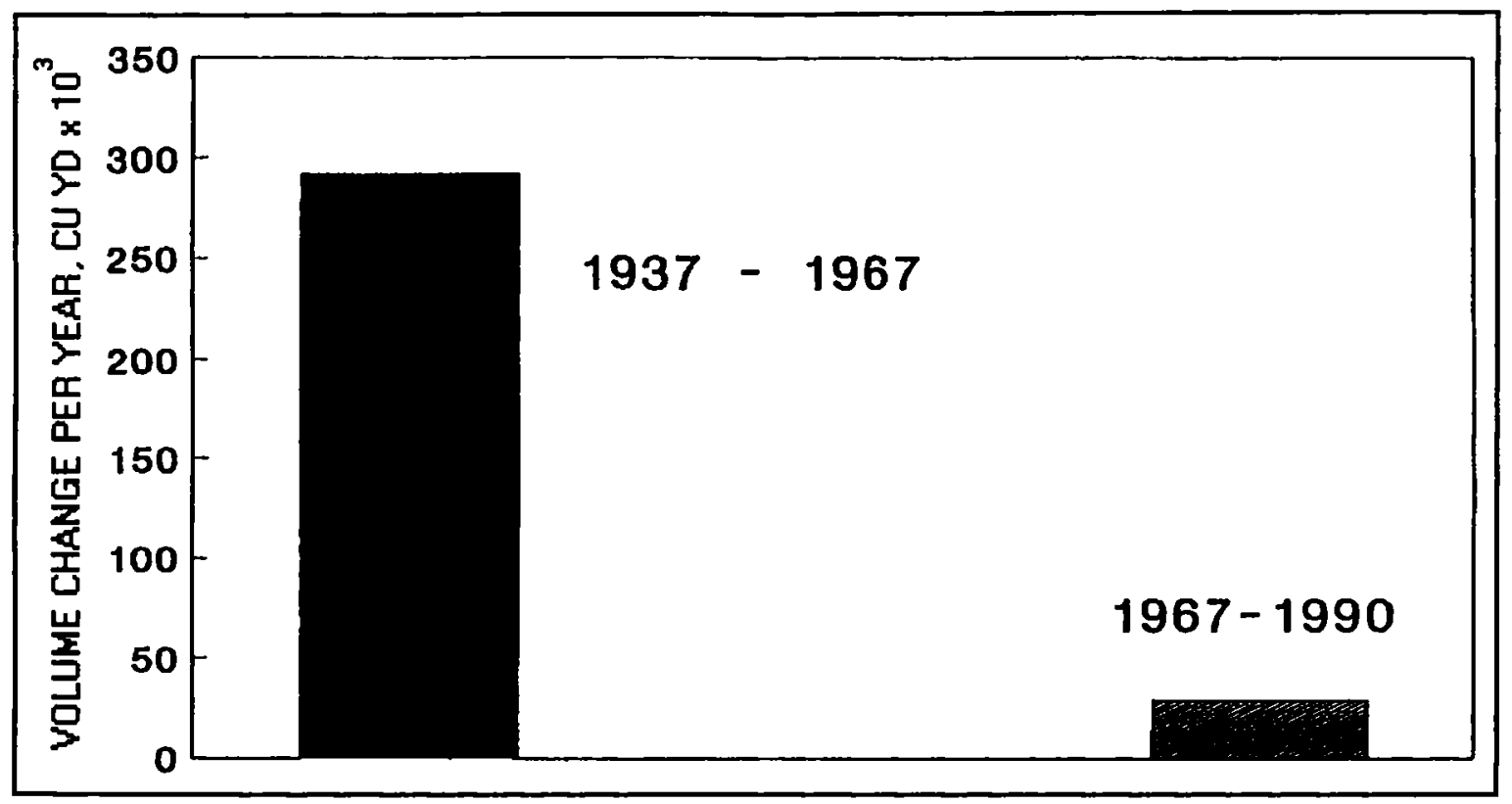

Figure 34. Ebb delta growth rate per year, 1937 to 1967 vs. 1967 to 1990

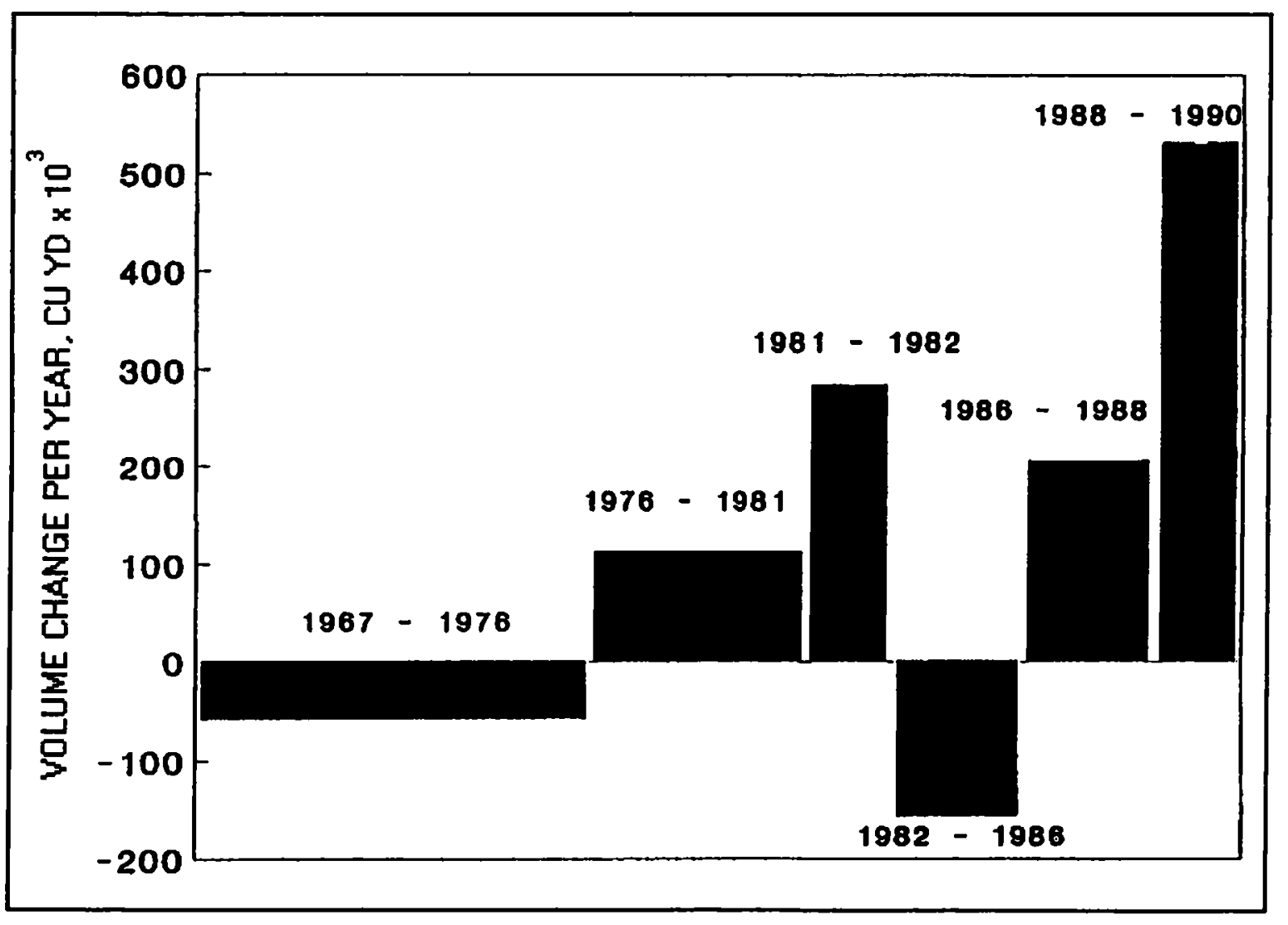

Figure 35. Ebb delta growth rate since 1967 


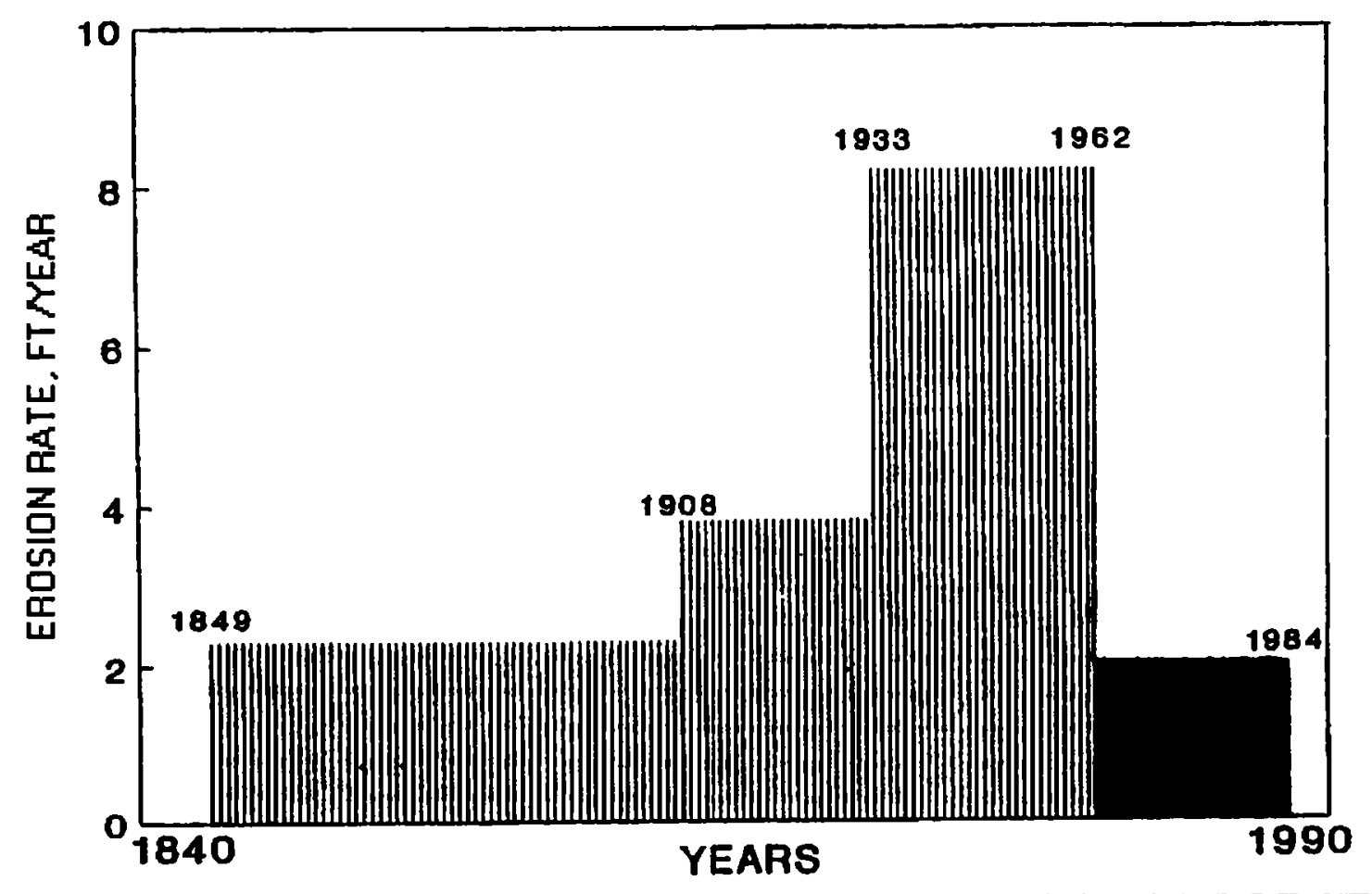

Figure 36. Historical shoreline erosion rate for northern Assateague Island. The light lined area represents data based on maps and air photos (Knowles 1985). The dark area is based on field profile surveys

\section{Scour Hole Stabilization}

In January 1984, the Baltimore District requested that CERC conduct two side scan sonar (SSS) inspections of the South Jetty Major Rehabilitation Project. The integrity of the south jetty had been threatened by a tendency for the main tidal flow to channelize along the north side of the outer section, causing a deep scour hole. As part of the major rehabilitation, the Baltimore District required the construction contractor to hydraulically place sand fill into the scour hole with an 18-in. (later modified to 24 in.) stone blanket, and construct a stone berm at the base of the existing jetty. The stone blanket was specified as a $2,000-\mathrm{ft}$-long and $200-\mathrm{ft}$ wide rectangular zone. The purpose of the side scan sonar inspection was to document the sand-filling operation and uniformity of the stone cover. This work provided the Baltimore District with a method of quality assurance for documenting the critical stone blanket product. The first inspection was accomplished during the week of 30 August 1984. Another scour hole inspection was completed in June 1990, which allowed further evaluation of infilling of the scour hole since 1984 . The results of these inspections indicated no subsequent erosion from 1984 (initial infilling) to 1990 (Figure 37). 


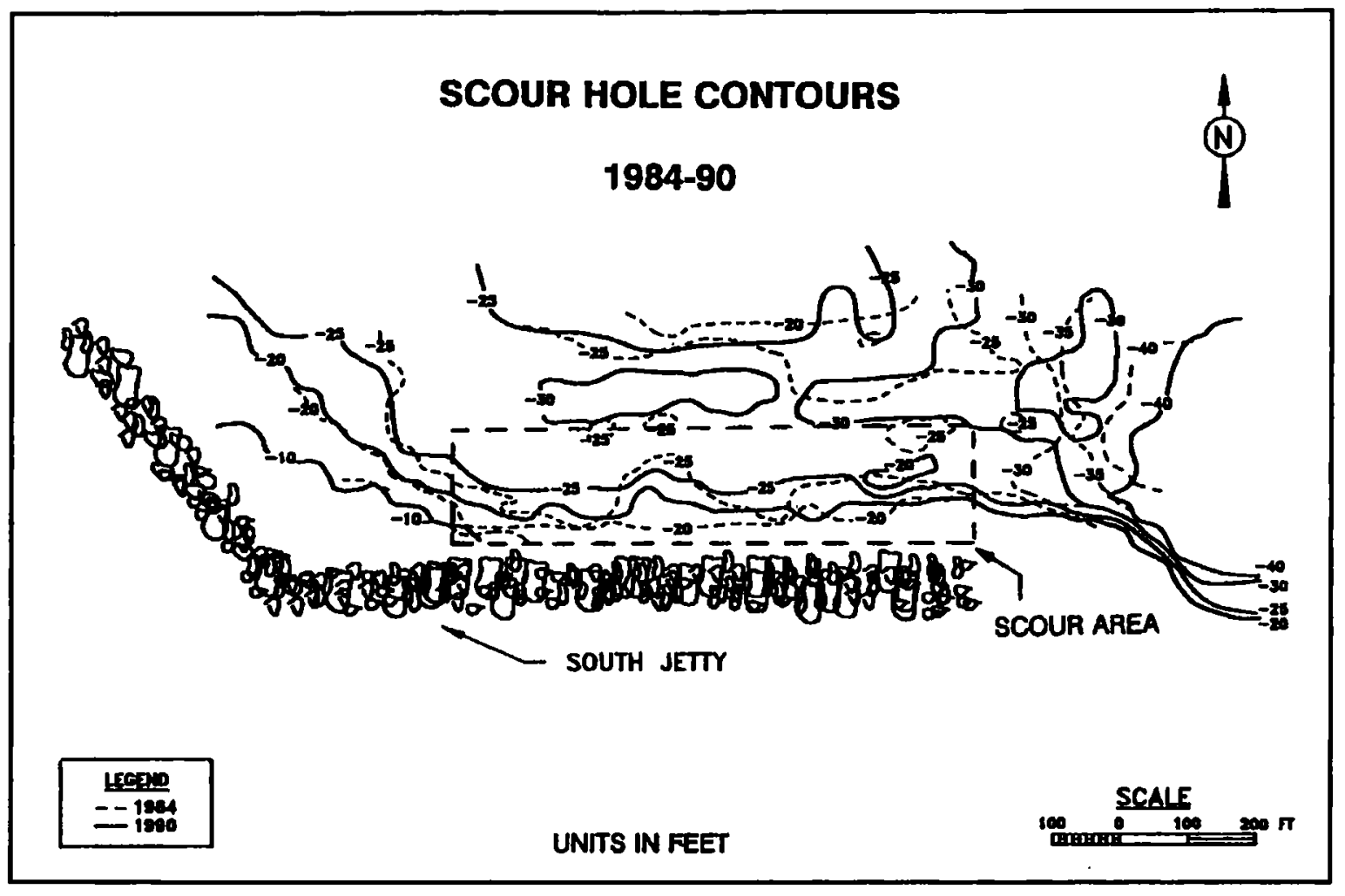

Figure 37. Scour hole contours indicating no erosion from 1984 to 1990 


\section{Conclusions}

Following rehabilitation, the south jetty performed as expected confirming the conclusions of preconstruction studies regarding the source of the finger shoal material. The rehabilitated jetty successfully acted to eliminate the source of material to the problem shoal area as demonstrated by the significant accretion of sand on the south side of the jetty and stabilization of northern Assateague Island. As a result, the problem finger shoal was eliminated.

The sand-tightened cross-section of the jetty has functioned as an effective littoral barrier and has trapped a high percentage of longshore transported material in this area, as evidenced by the accretion south of the jetty. Prior to reconstruction this material would have been permitted to pass through the jetty into the problem area. As a result of the elevation of this sediment accretion relative to the crest elevation of the south jetty, some transport of sand due to wind action is occurring.

The headland breakwaters constructed along the northern shoreline of Assateague Island have effectively stabilized the shoreline. The crenulate embayments between the breakwater segments have, in general, evolved as expected following breakwater construction. The response of the shoreline in this area confirms the preconstruction concerns regarding the potential erosion of the shoreline following the south jetty rehabilitation. Without the headland breakwaters, it is probable that significant erosion of the northern Assateague shoreline would have occurred.

The distribution of longshore transport across the surf zone, as represented by the distribution of volumetric accretion on the south side of the jetty, showed trends similar to previous investigations. However, the lack of directional wave data precluded any in-depth analysis of the distribution.

The response of Assateague's northern shoreline and the profiles south of the jetty were generally as expected, particularly the oceanward advancement of the shoreline due to the enhanced sand-trapping ability of the rehabilitated jetty. Accretion from the sand tightening caused initial steepening of the profiles near the jetty. Later offshore transport of sand occurred with the subsequent flattening of the profiles. 
The volume of sediment contained in Ocean City Inlet's ebb-tidal delta increased steadily from 1934 to 1967 . Since 1967 the rate of shoal growth has decreased markedly. The averaged growth rates were shown to be $353,000 \mathrm{cu} y d / y e a r$ and $39,000 \mathrm{cu}$ yd/year, respectively. These data show that the volume of the ebb-tidal delta increased rapidly after jetty construction but has gradually tapered to present day rates as a state of equilibrium is approached. Northern Assateague Island has exhibited a decrease in shoreline erosion since the late 1960's, corresponding to the slower rate of shoal growth since 1967 (Figure 38). As the system moves toward equilibrium, more and more sediment may be bypassed, resulting in less severe erosion of the northern Assateague shoreline.

Results from this study of ebb shoal evolution suggest that natural bypassing of sand around Ocean City Inlet is an important process influencing shoreline change in the region. Further investigations are planned to fully document sediment bypassing at Ocean City Inlet. These include:

(1) updating shoreline change measurements, (2) adding and updating bathymetry data, and (3) correlating process data (storms, waves, etc.) with measured shoal growth since 1967. This information should help improve shoreline erosion prediction estimates for northern Assateague Island. Preliminary examination of bathymetric shoal data, along with shoreline change data, support predictions of reduced erosion rates along Northern Assateague Island, suggesting that natural sediment bypassing is presently occurring.

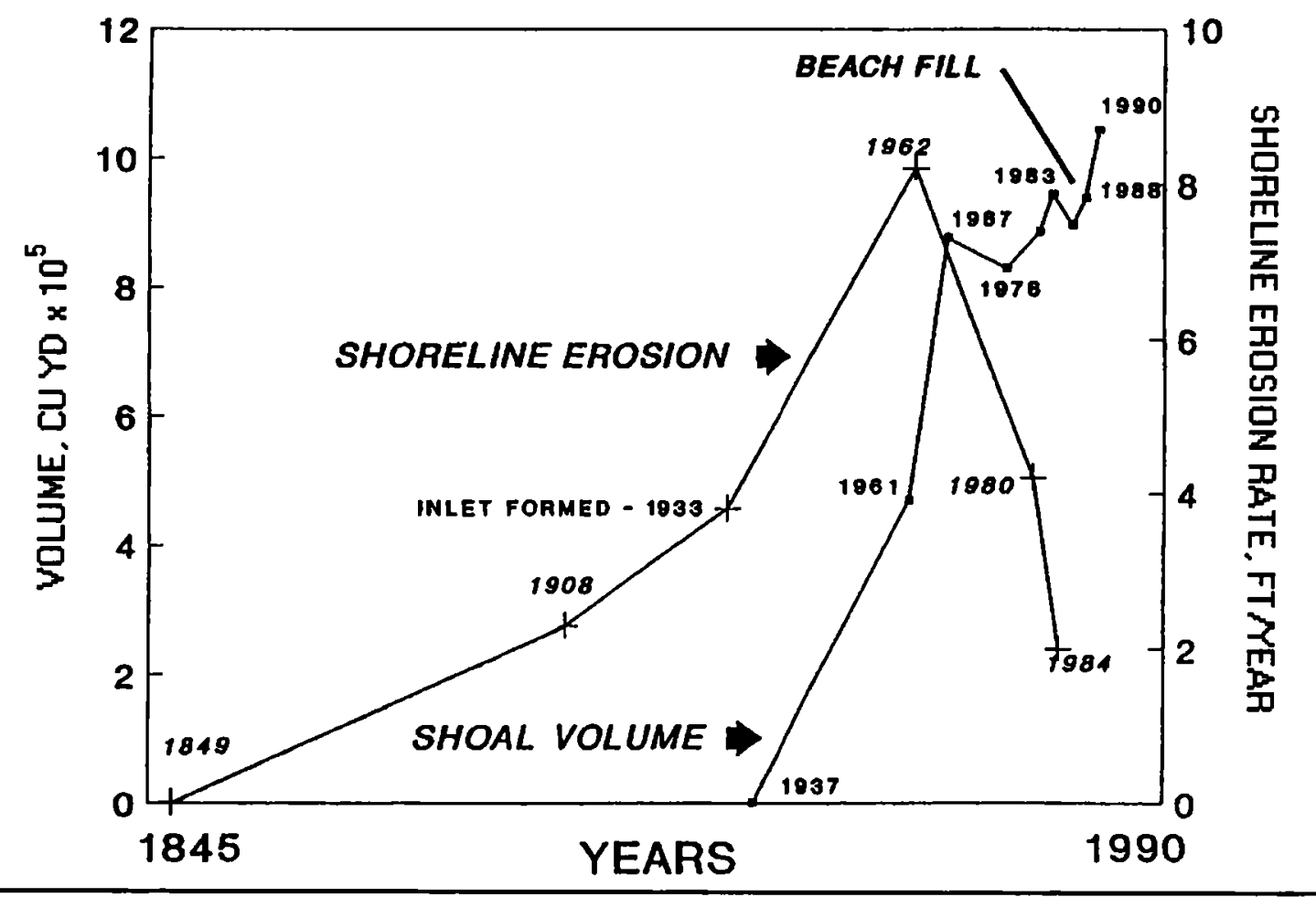

Figure 38. Cumulative shoal volume vs. change in Assateague Island's northern shoreline erosion rates 


\section{References}

Berek, E. P., and Dean, R. G. (1982). "Field investigation of longshore transport distribution." Proceedings, 18th International Conference on Coastal Engineering. American Society of Civil Engineers, 1620-1639.

Bijker, E. W. (1971). "Longshore transport computations," Journal of Waterways, Harbors, and Coastal Engineering Division, American Society of Civil Engineers, WW4, 687-701.

Bodge, K. R., and Dean, R. G. (1987). "Short-term impoundment of longshore transport." Proceedings of Coastal Sediments '87. American Society of Civil Engineers, 468-483.

Davies, J. L. (1958). "Wave refraction and the evolution of shoreline curves." Geophysical Studies, 5.

Dean, R. G., and Perlin, M. (1977). "Coastal engineering study of Ocean City Inlet, Maryland." Proceedings of Coastal Sediments '77, American Society of Civil Engineers, 520-542.

Fulford, E. T. (1982). "Distribution of longshore sediment transport across the surf zone," Master's Thesis, Department of Civil Engineering, University of Delaware, Newark, Delaware.

Hudson, R. (1958). "Design of quarry-stone cover layers for rubble-mound breakwater," Research Report No. 22, U.S. Army Engineer Waterways Experiment Station, Vicksburg, MS.

Knowles, S. C. (1985). "Ocean City Inlet: A catalyst for coastal change." Presentation, Geological Society of America, Annual Meeting. Orlando, FL.

Komar, P. D. (1977). "Longshore currents and sand transport on beaches," Journal of Geophysical Research, 76, (3), 333-354.

Leatherman, S. P. (1979). "Migration of Assateague Island, Maryland by inlet and overwash processes," Geology 7, 104-107. 
Lewis, W. V. (1938). "The evolution of shoreline curves." Proceedings Geologists' Association. XLIX, 107-126.

Sawaragi, T., and Deguchi, I. (1978). "Distribution of sand transport rate across a surf zone." Proceedings of 16th Coastal Engineering Conference. American Society of Civil Engineers, 1596-1613.

Silvester, R. (1970). "Growth of crenulate shaped bays to equilibrium," Journal of Waterways, Ports, Harbors, and Coastal Engineering, American Society of Civil Engineers. 96(WW2), 275-287.

Silvester, R., and Ho, S. K. (1972). "Use of crenulate shaped bays to stabilize coasts." Proceedings of International Conference on Coastal Engineering. American Society of Civil Engineers. 1347-1365.

Thornton, E. B. (1973). "Distribution of sediment transport across the surf zone." Proceedings of 13th Coastal Engineering Conference. 1049-1068.

Underwood, S. G., and Anders, F. J. (1989). "A case study of ebb-tidal delta equilibrium: Ocean City Inlet, Maryland." Post-Proceedings of Coastal Zone '89. American Society of Civil Engineers.

U.S. Army Engineer District, Baltimore. (1982). "Rehabilitation of south jetty, Ocean City harbor and inlet and Sinepuxent Bay," Design Memorandum No. 3, Baltimore, MD.

Yasso, W. E. (1965). "Plan geometry of headland-bay beaches," Journal of Geology 73, 702-714. 


\section{Appendix A \\ Waverider Wave Buoy Data}

This section contains the nondirectional wave data collected by Datawell Waverider buoy located in approximately $50 \mathrm{ft}$ of water to the northeast of the south jetty. Two deployments of Waverider buoys were conducted due to malfunctions. The first deployment occurred 2 April 1986 and collected data through 23 January. 1987 with 18 days of down time occurring from 12 September 1986 through 4 December 1986. The gauge was lost sometime between the end of January and the end of February. The second deployment occurred on 25 February 1987 at the approximate location of the first buoy. Data collection continued through 6 November 1987. 


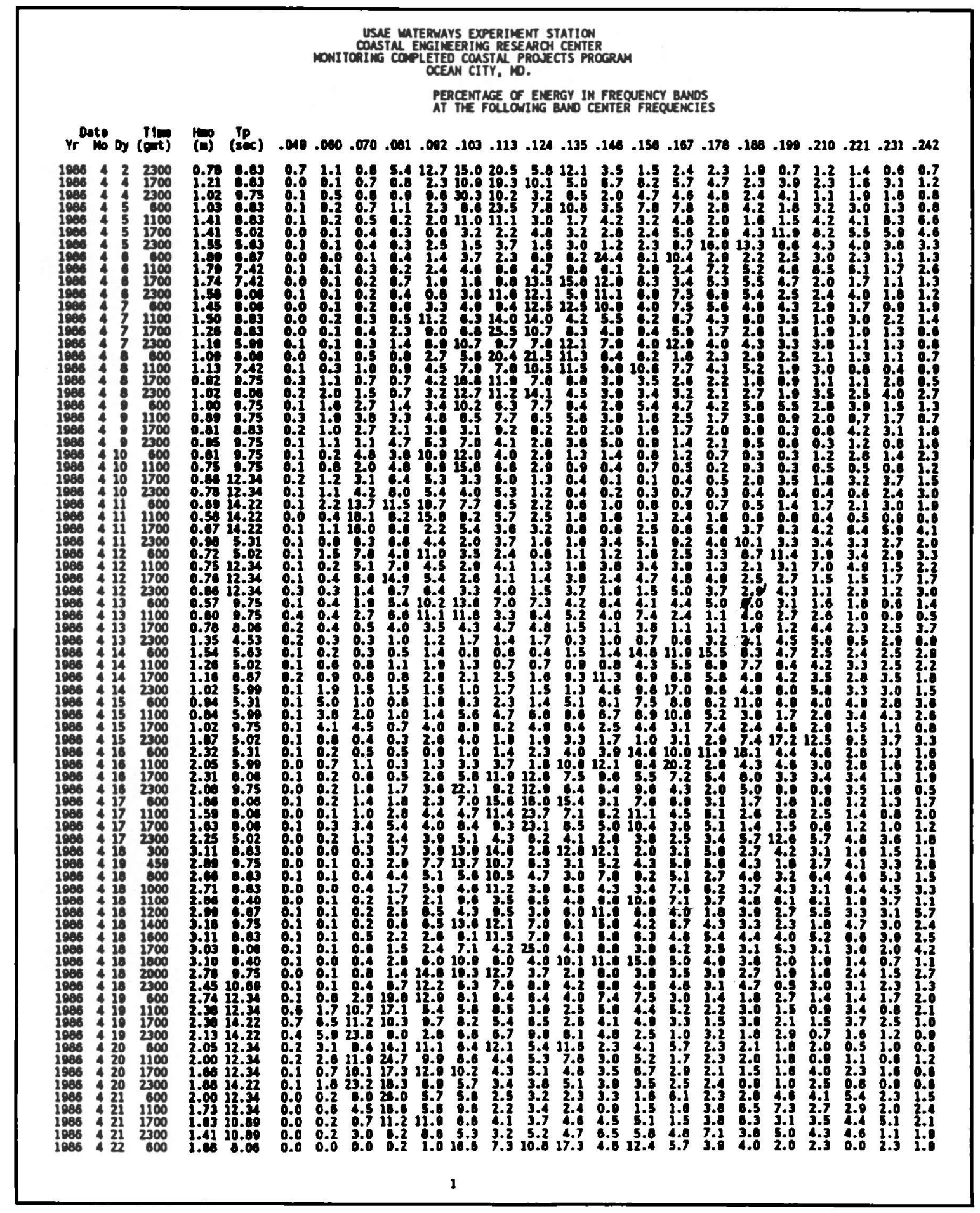




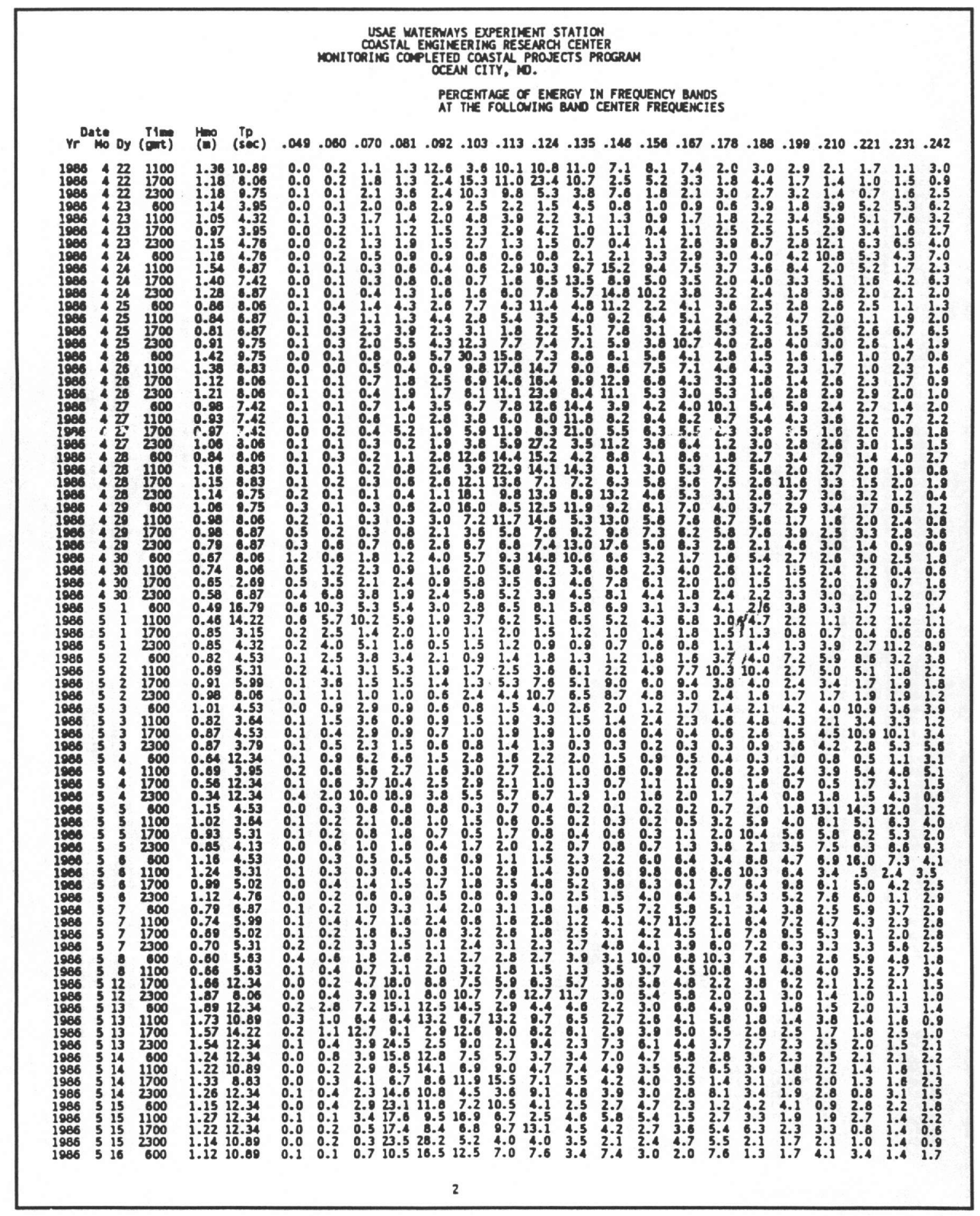




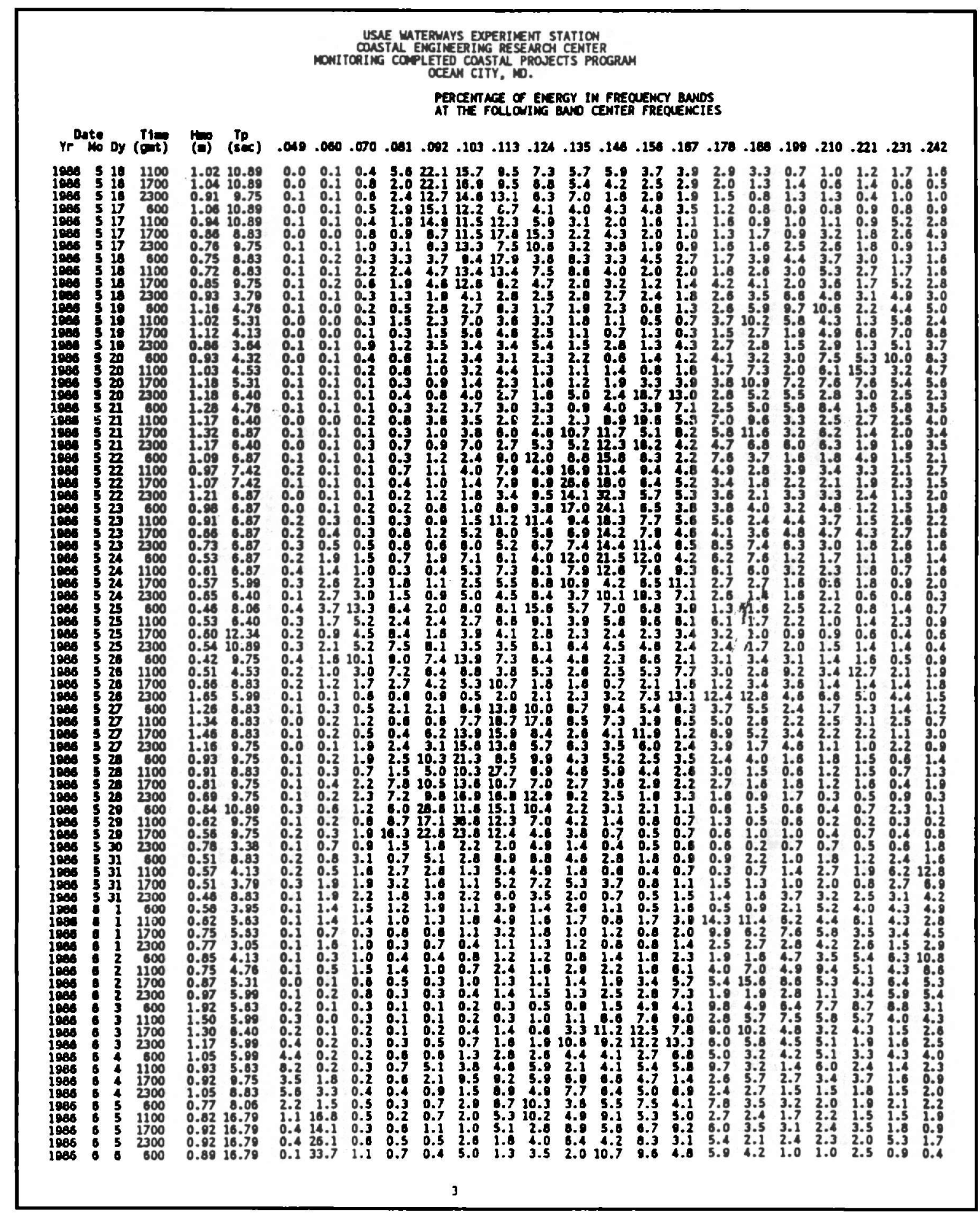




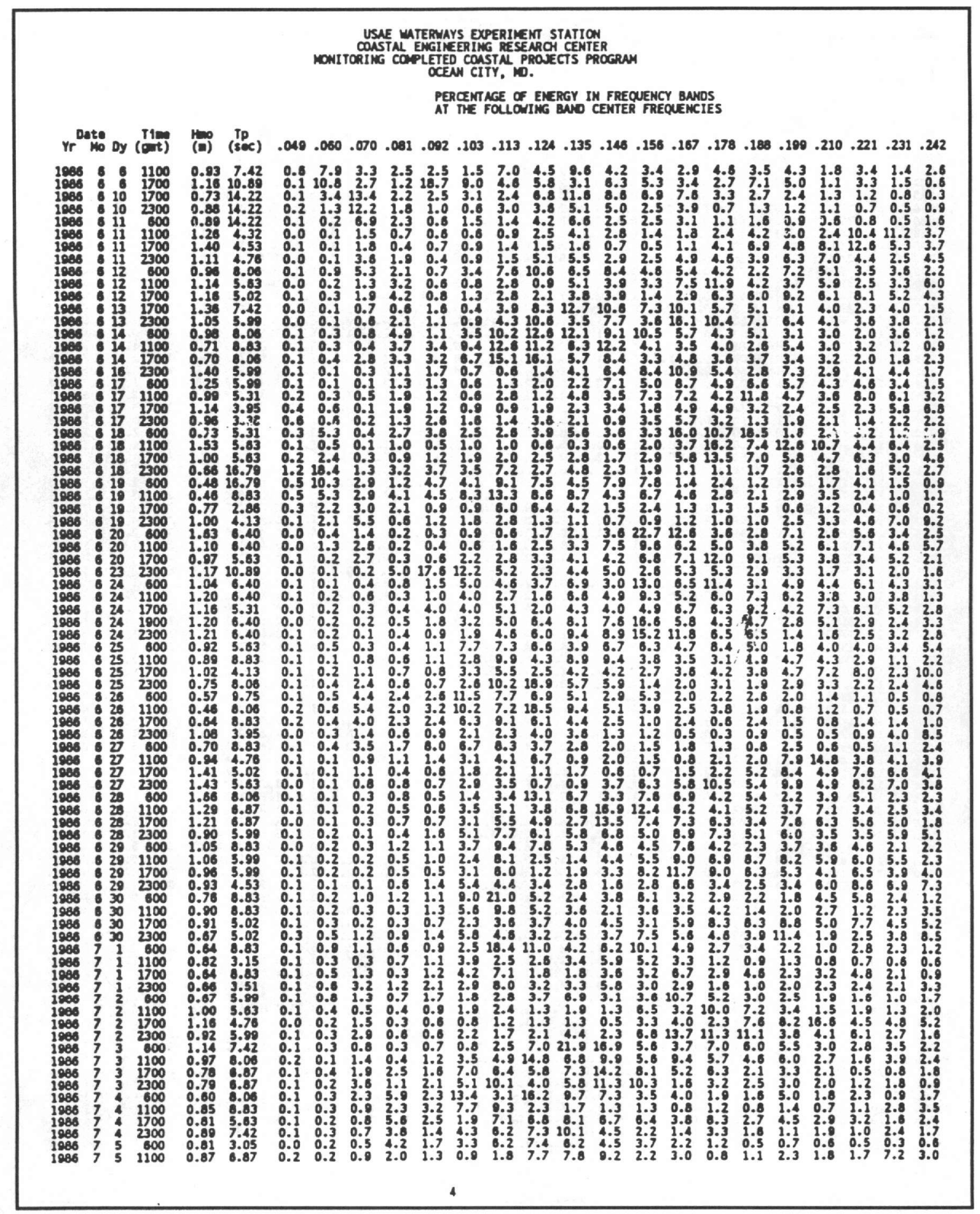




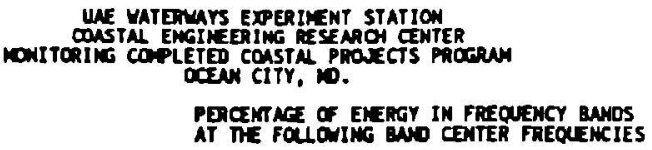

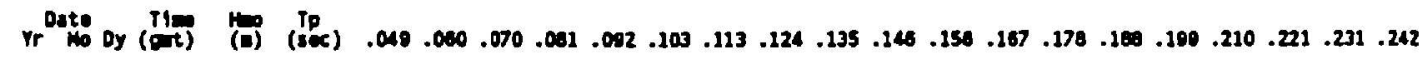

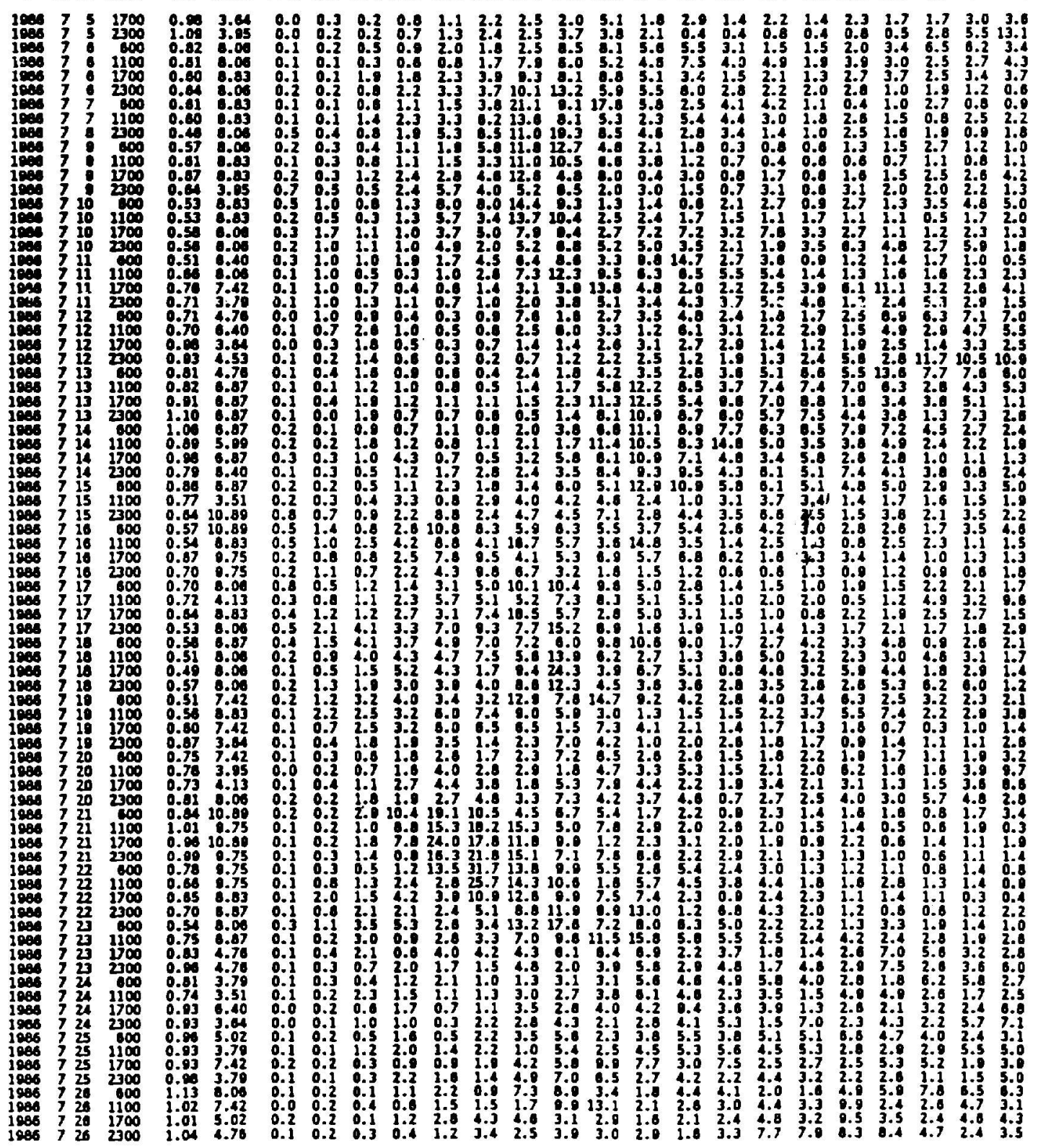




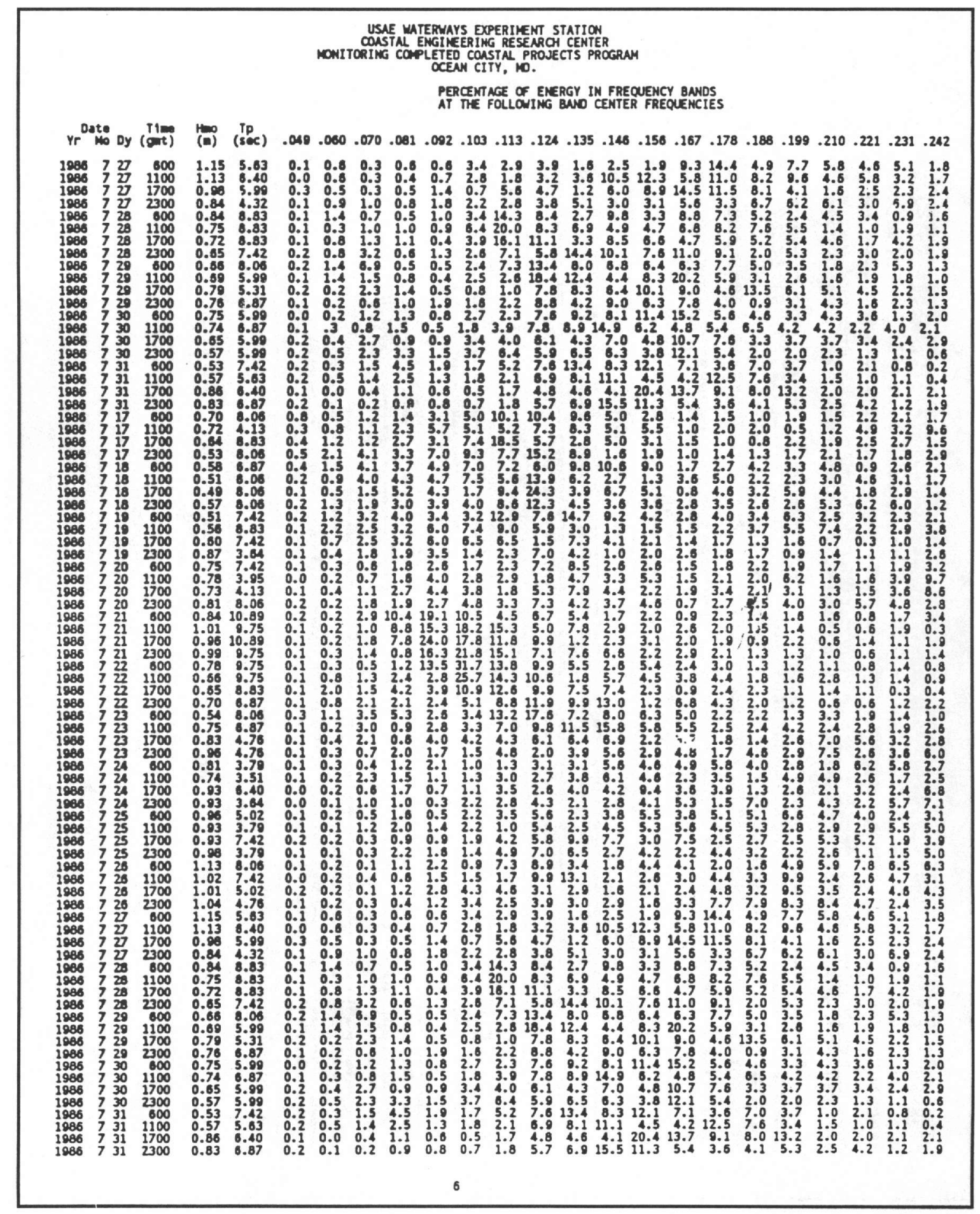




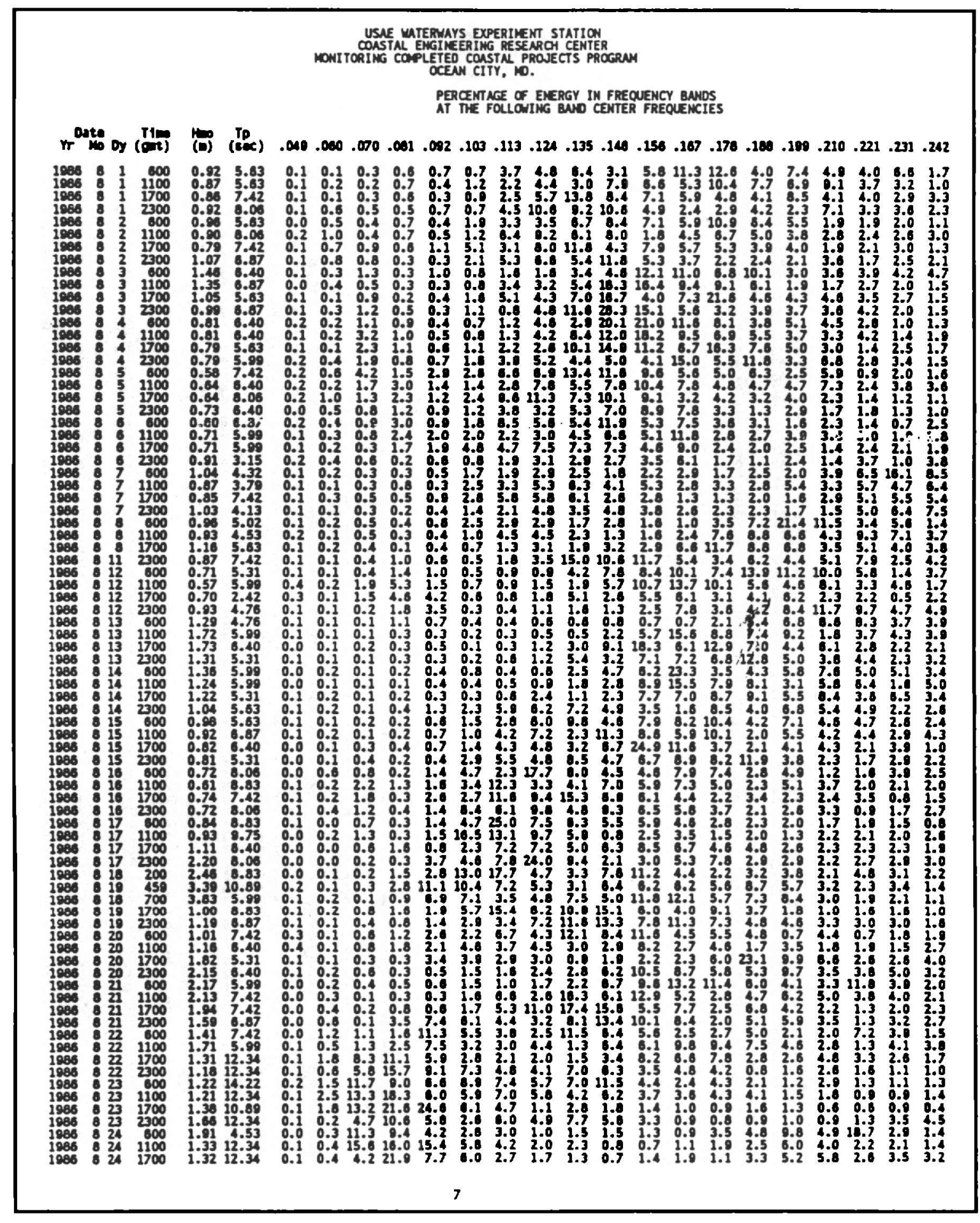




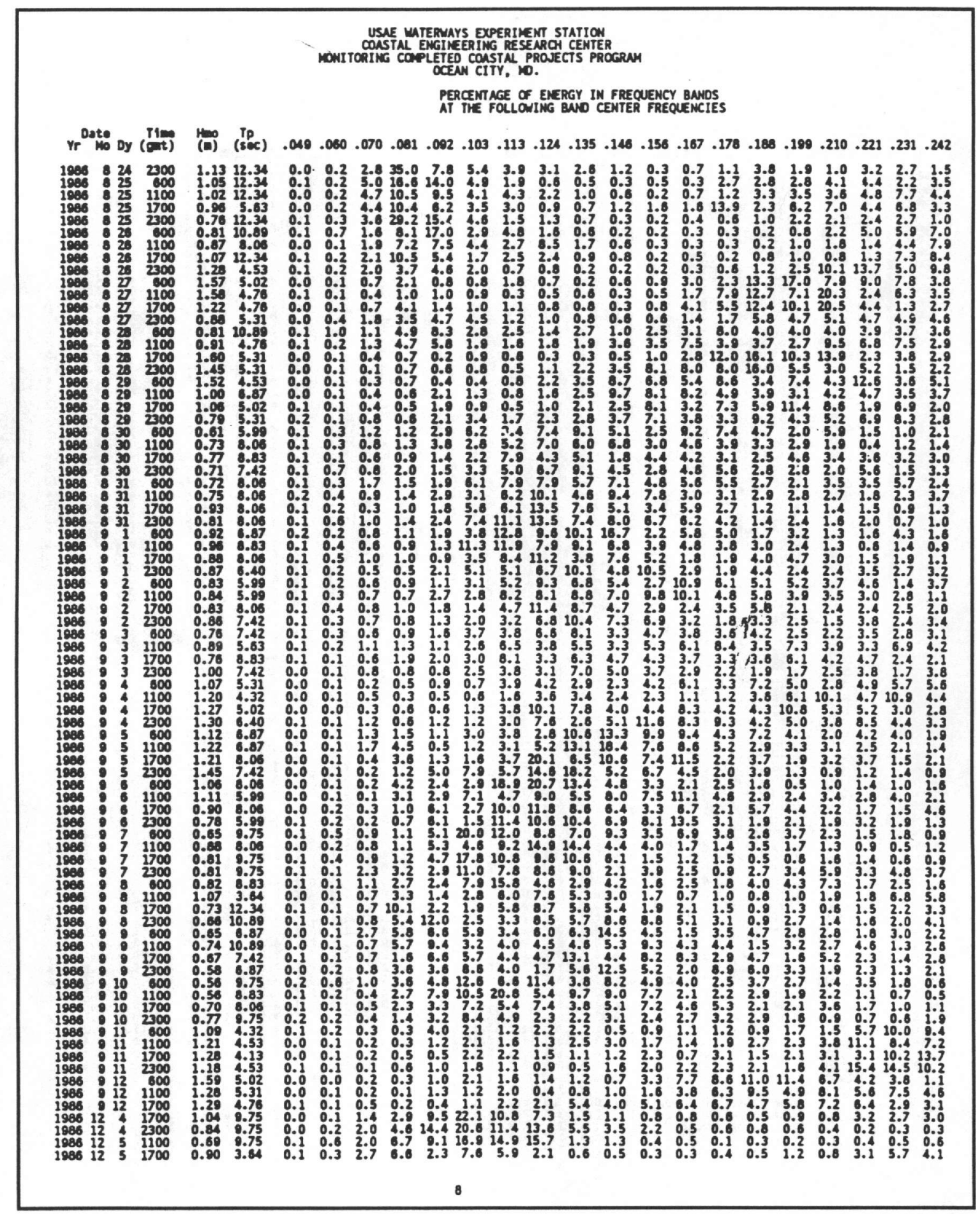




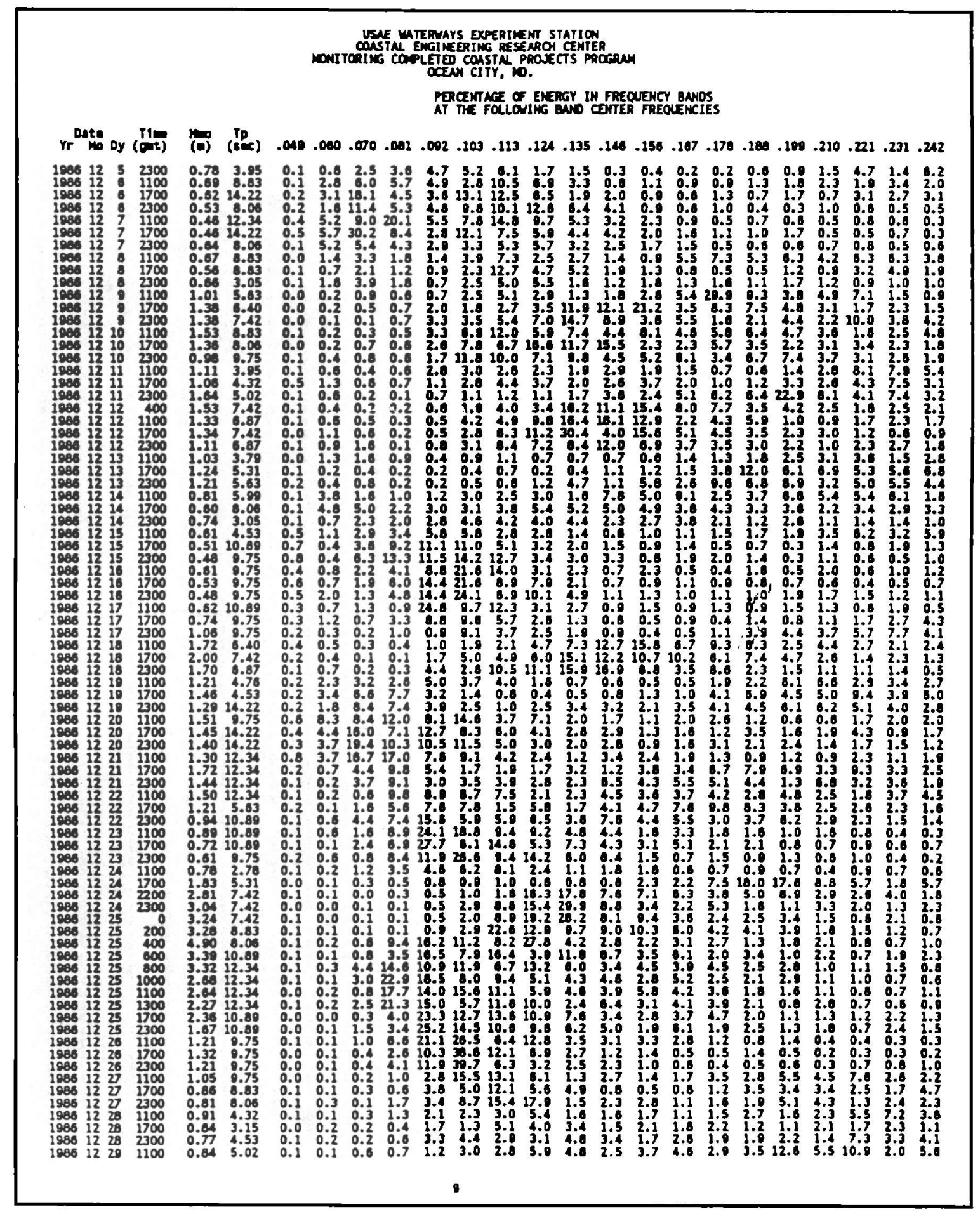




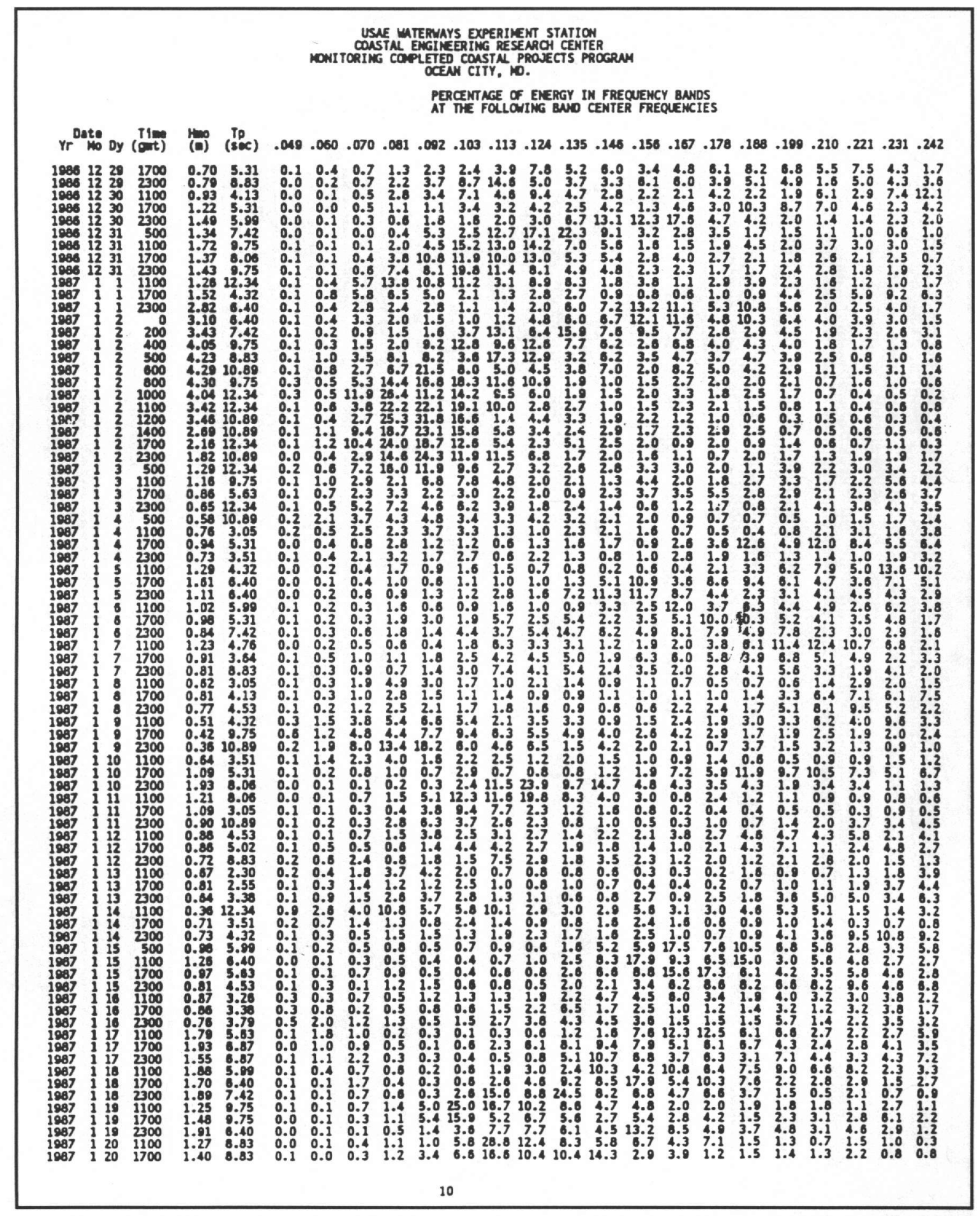




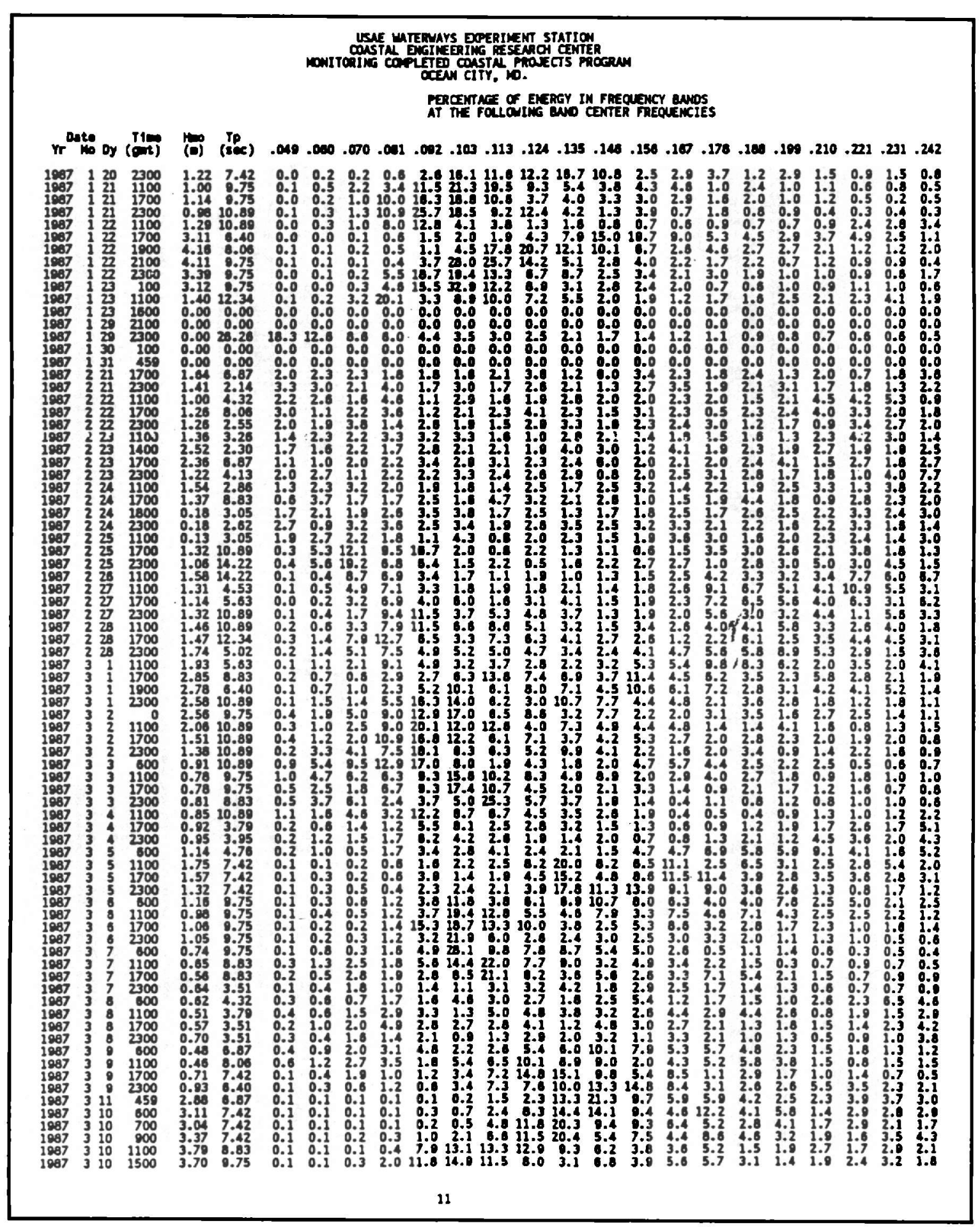




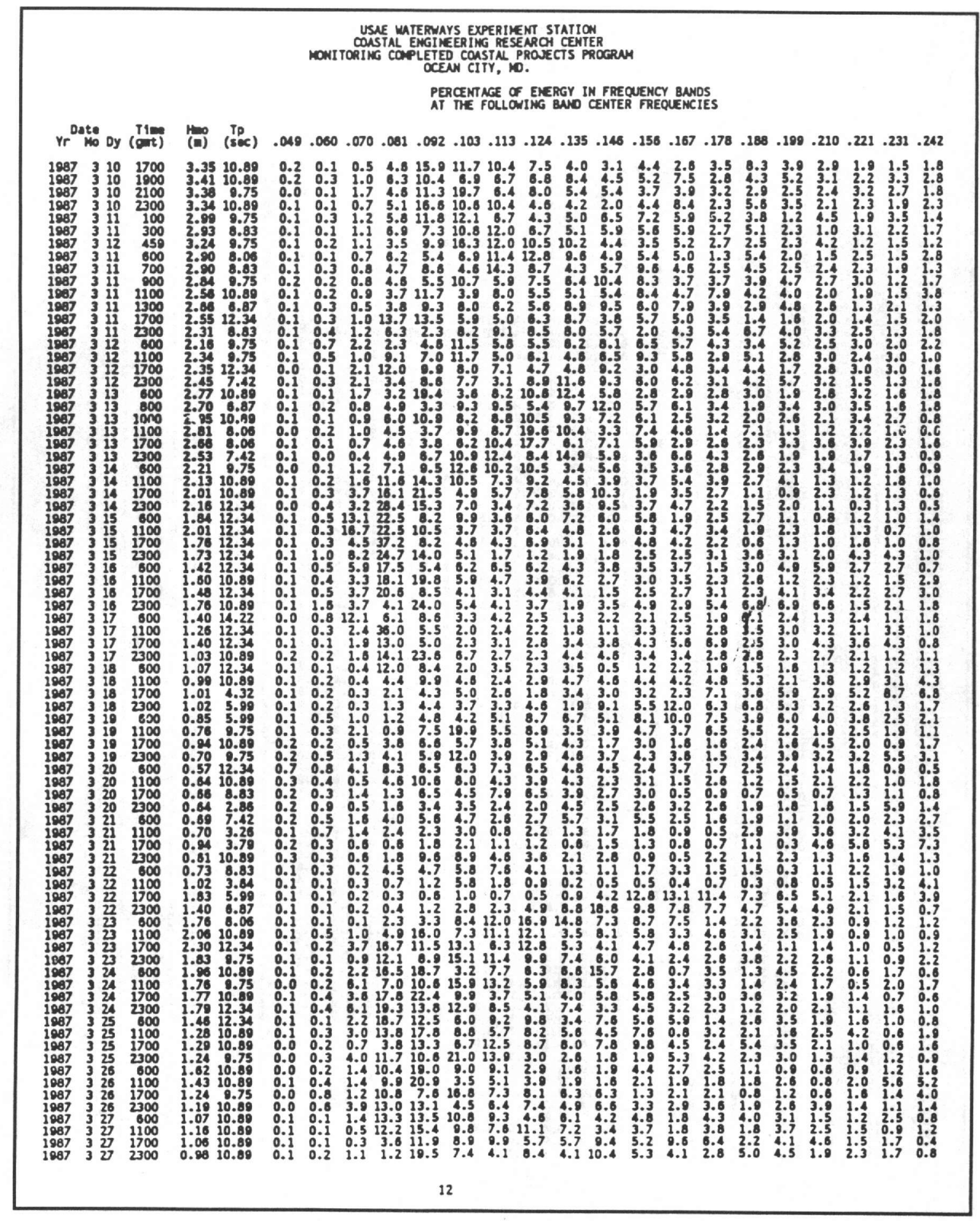

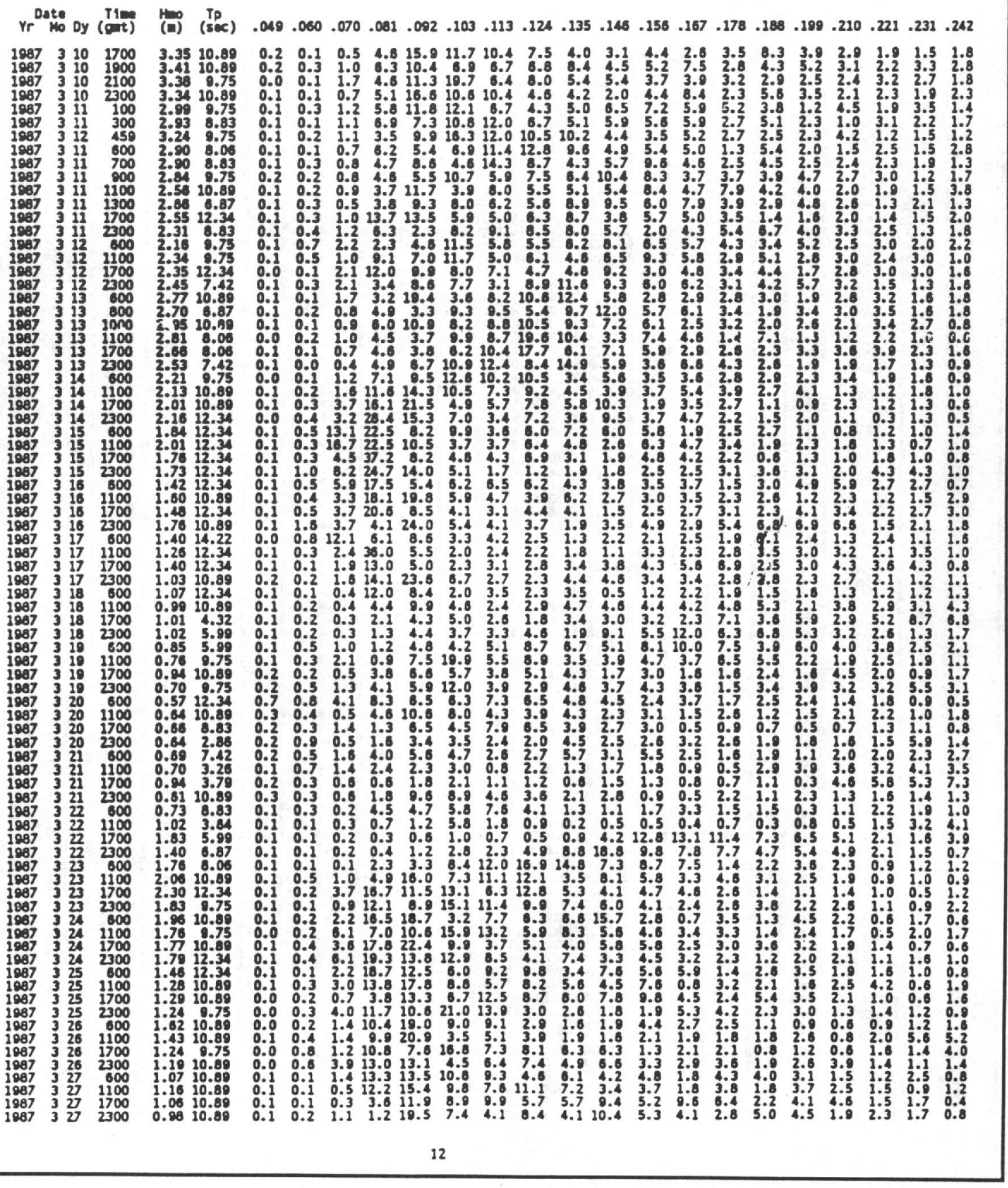




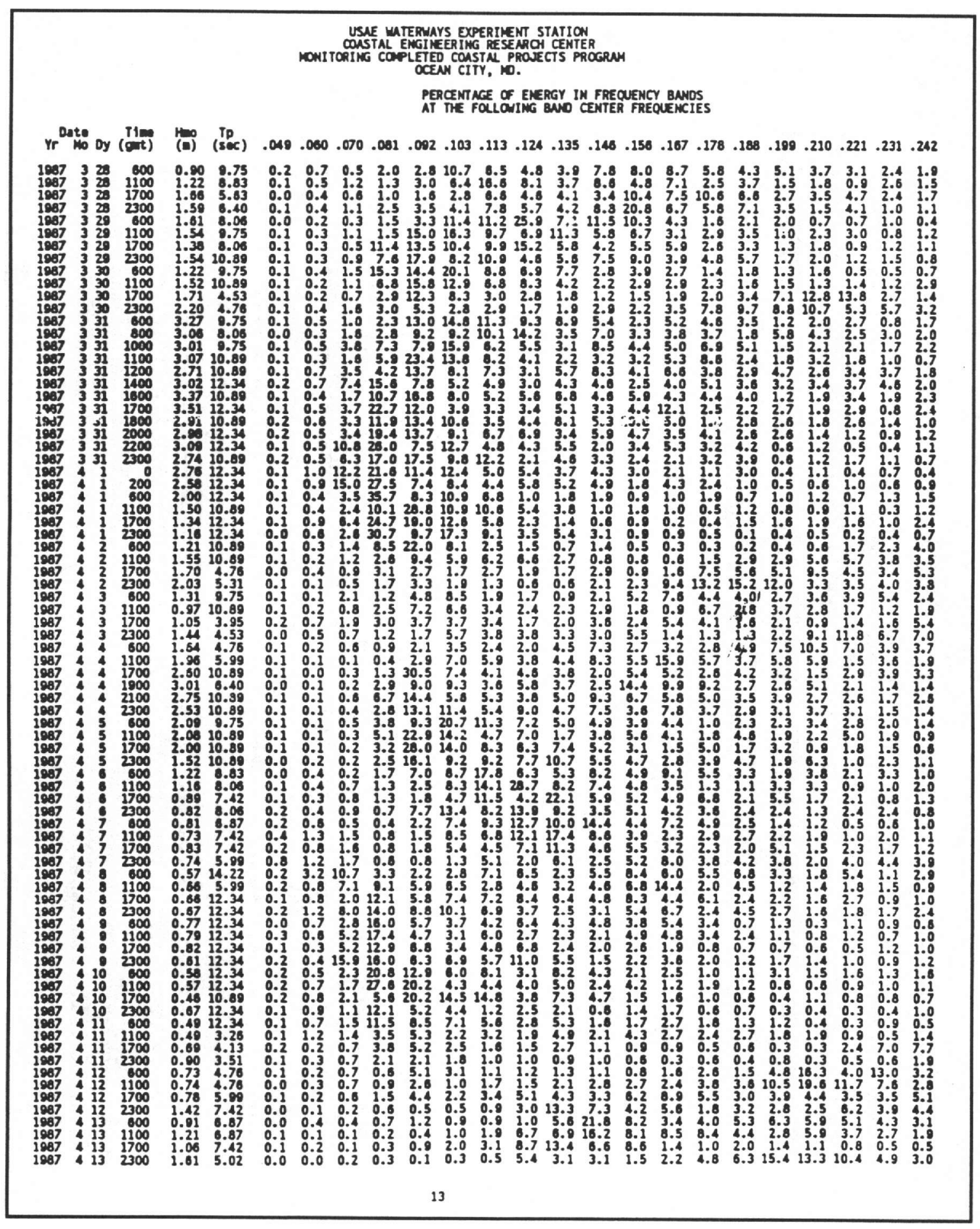




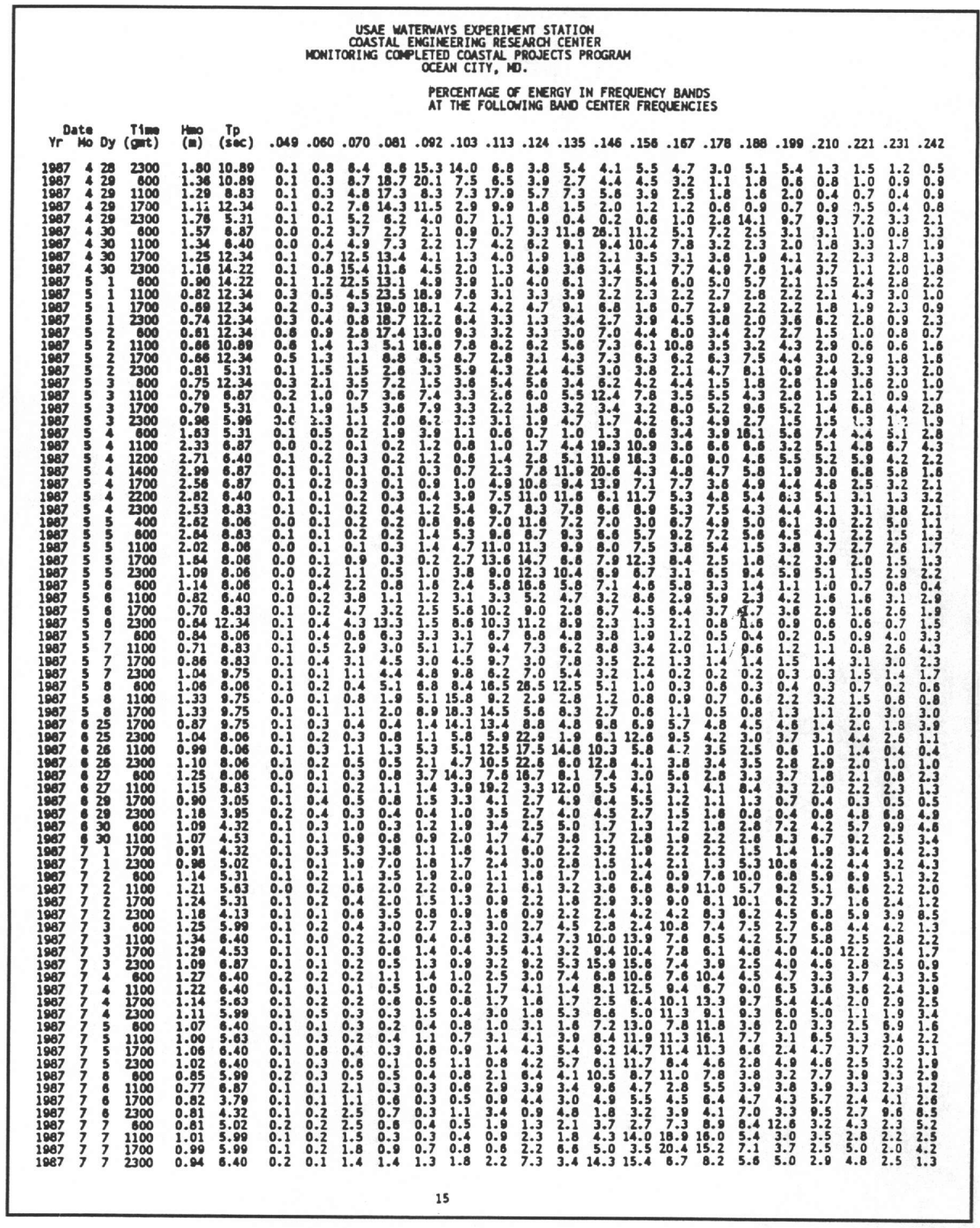


USAE MATERYAYS EXPERILENT STATIOW

NOWITORING COP LEIED COASTN PROEETS PROGRN

TY, 10.

PERCEMTACE G ENERGY TH FREQUENCY BANDS

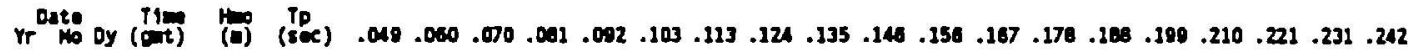

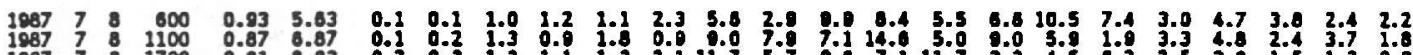

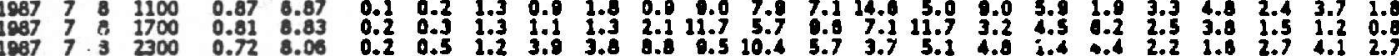
$19877-32200$

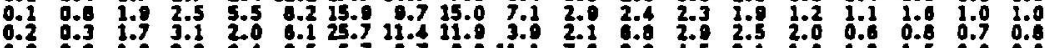

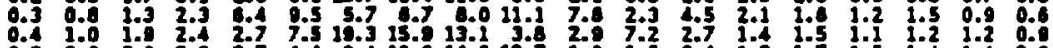

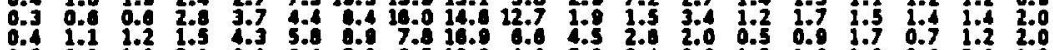

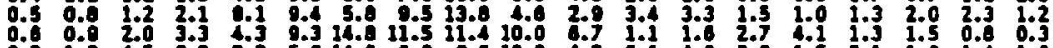

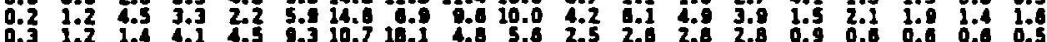

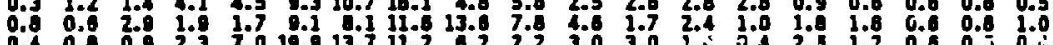

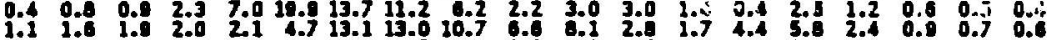

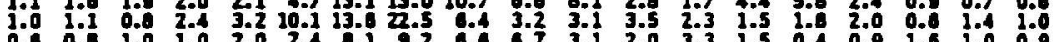

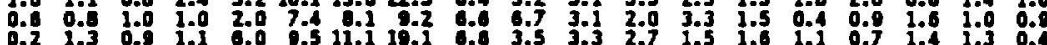

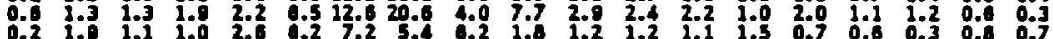

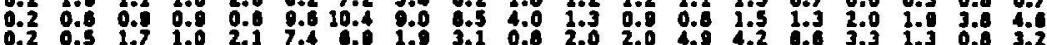

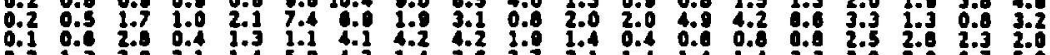

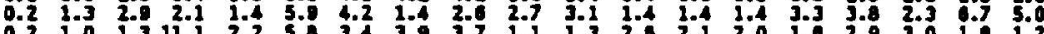

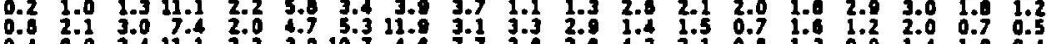

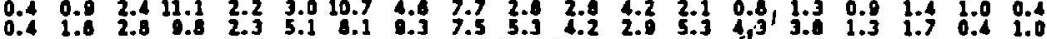

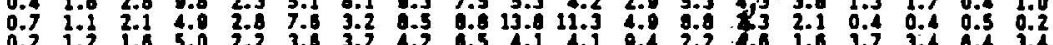

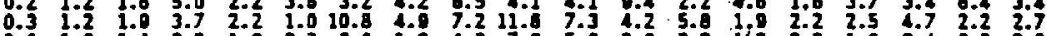

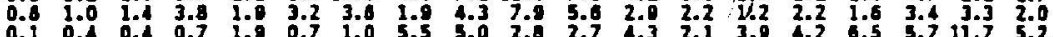

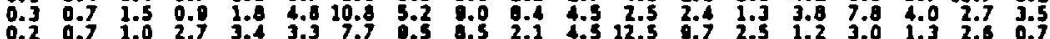

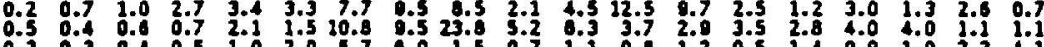

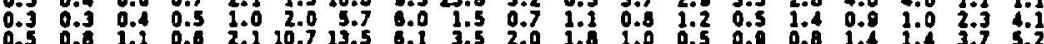

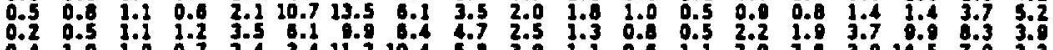
0.43 .0 l.

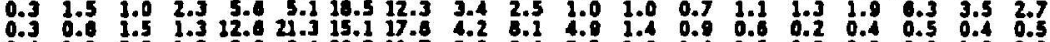

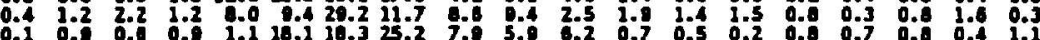

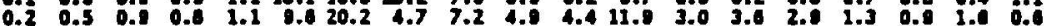

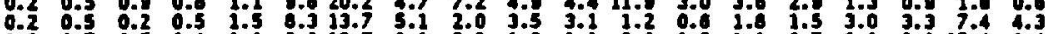

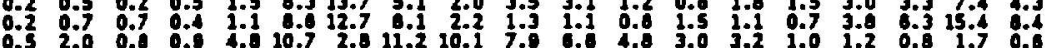

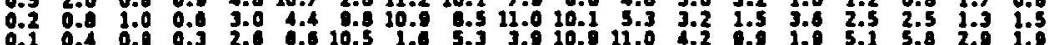

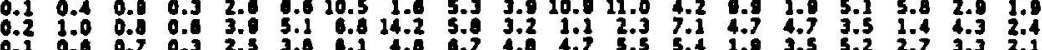

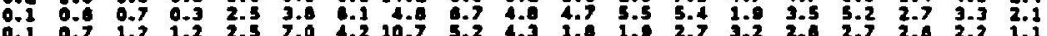

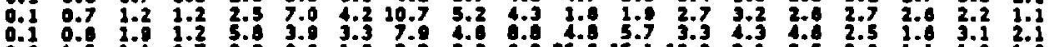

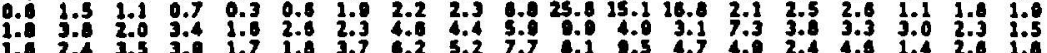

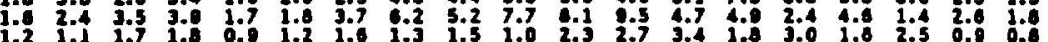

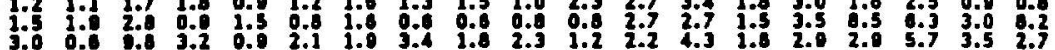

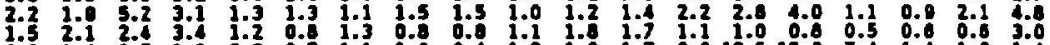

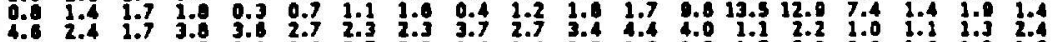

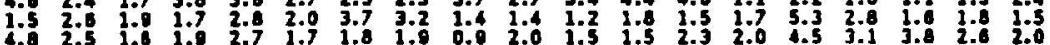

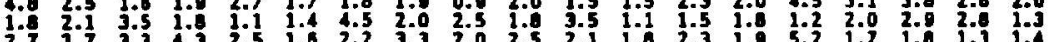

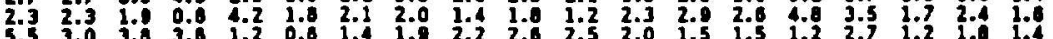

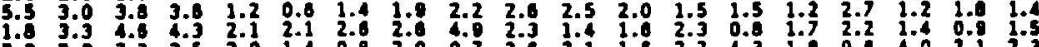

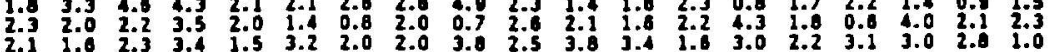




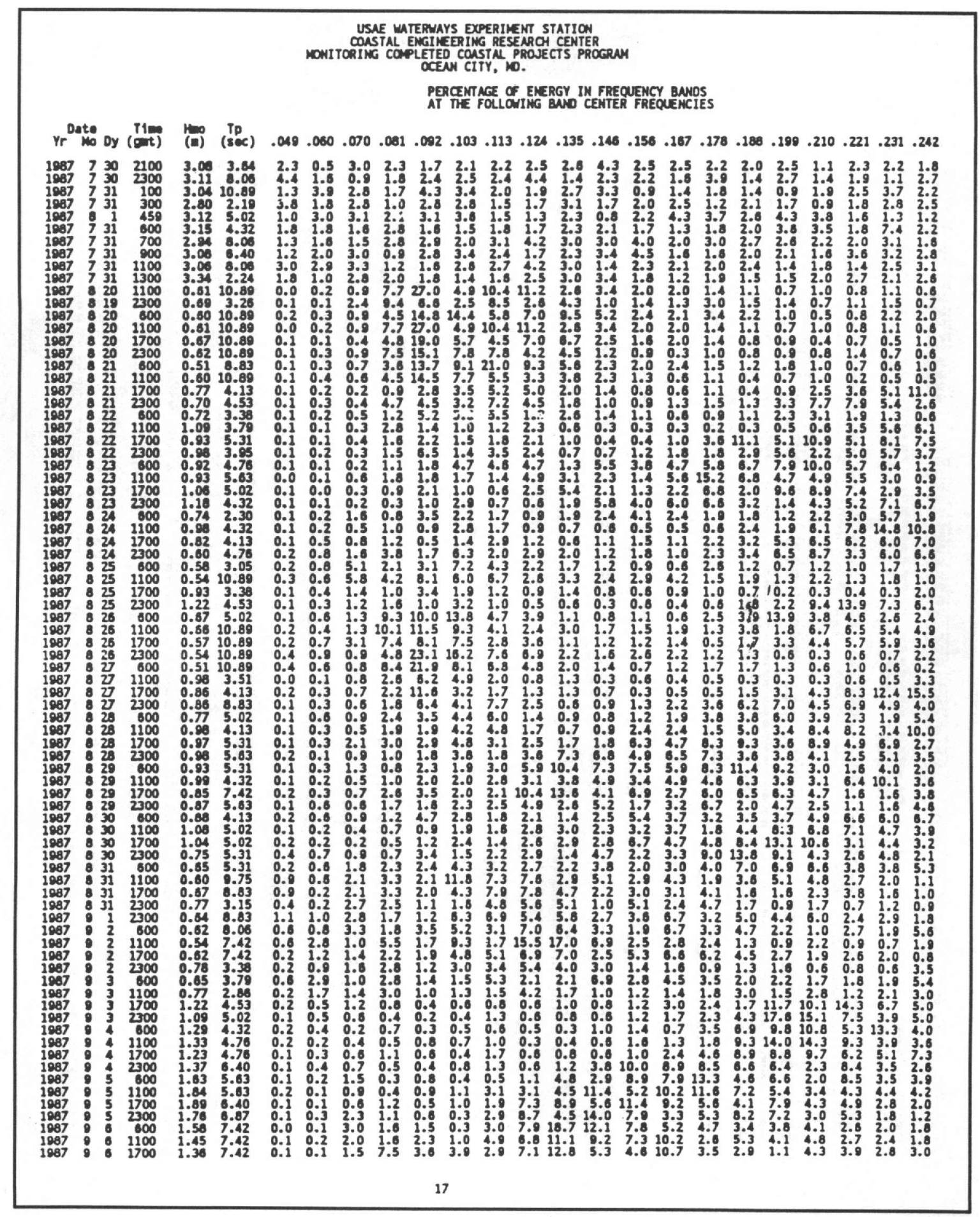




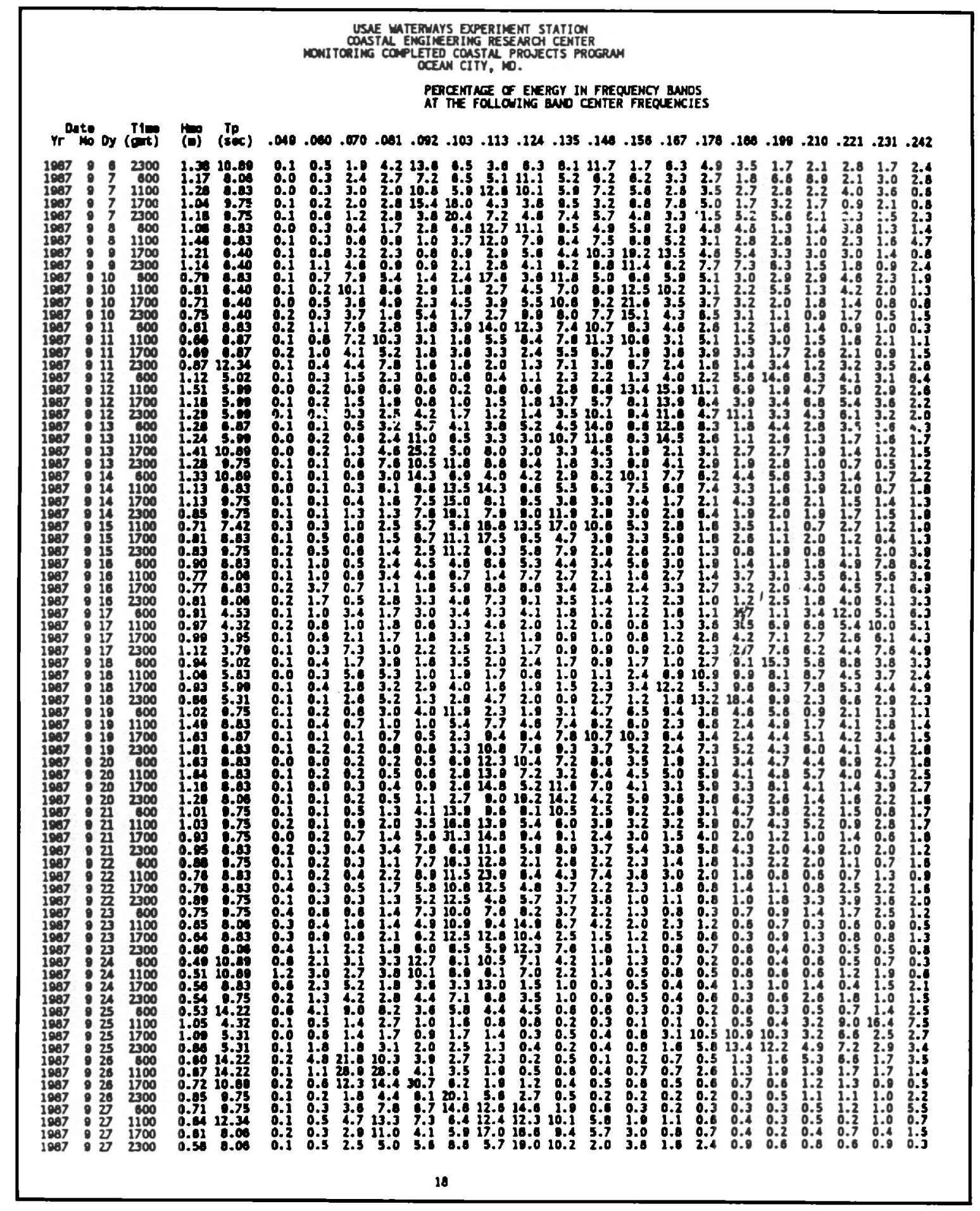




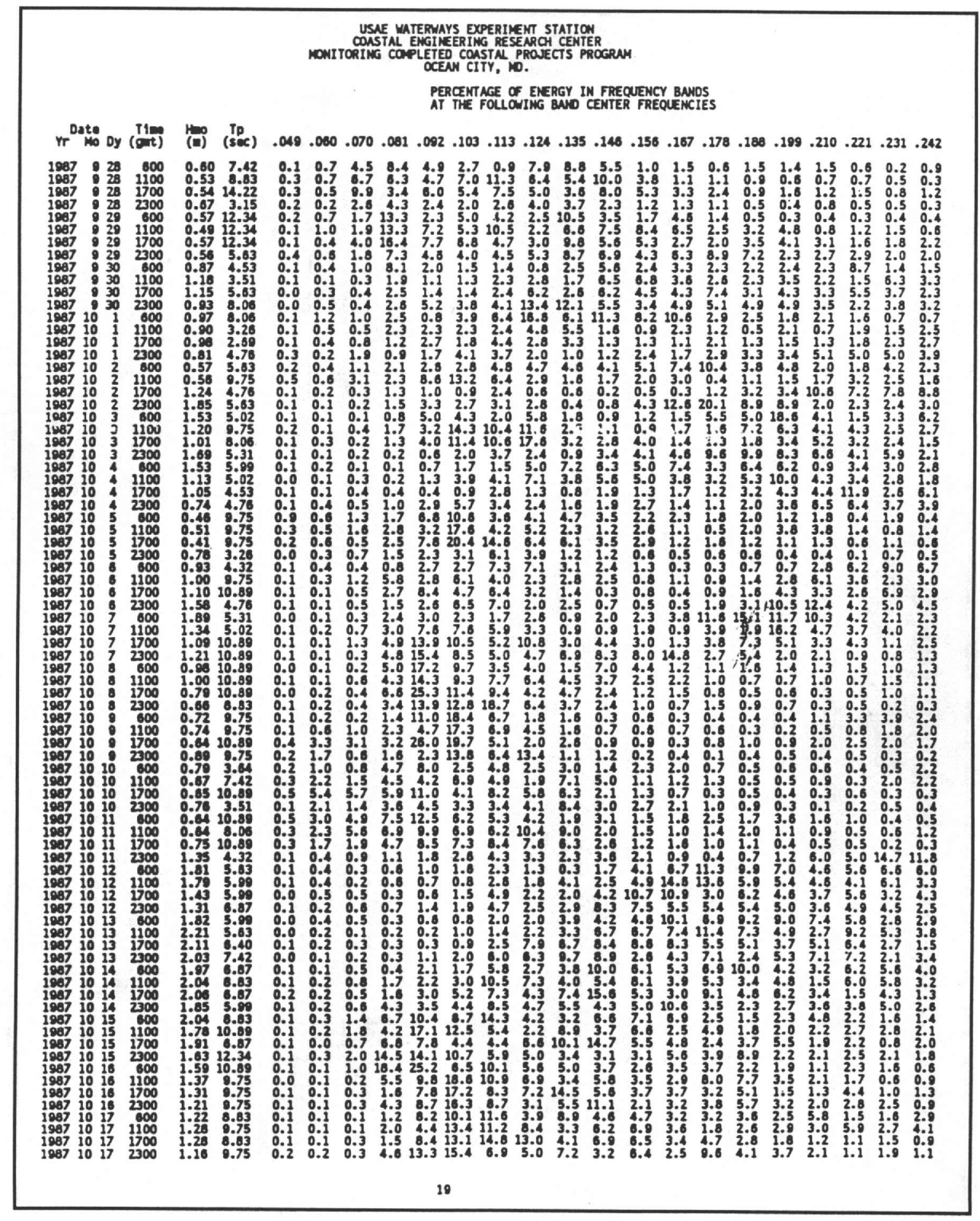




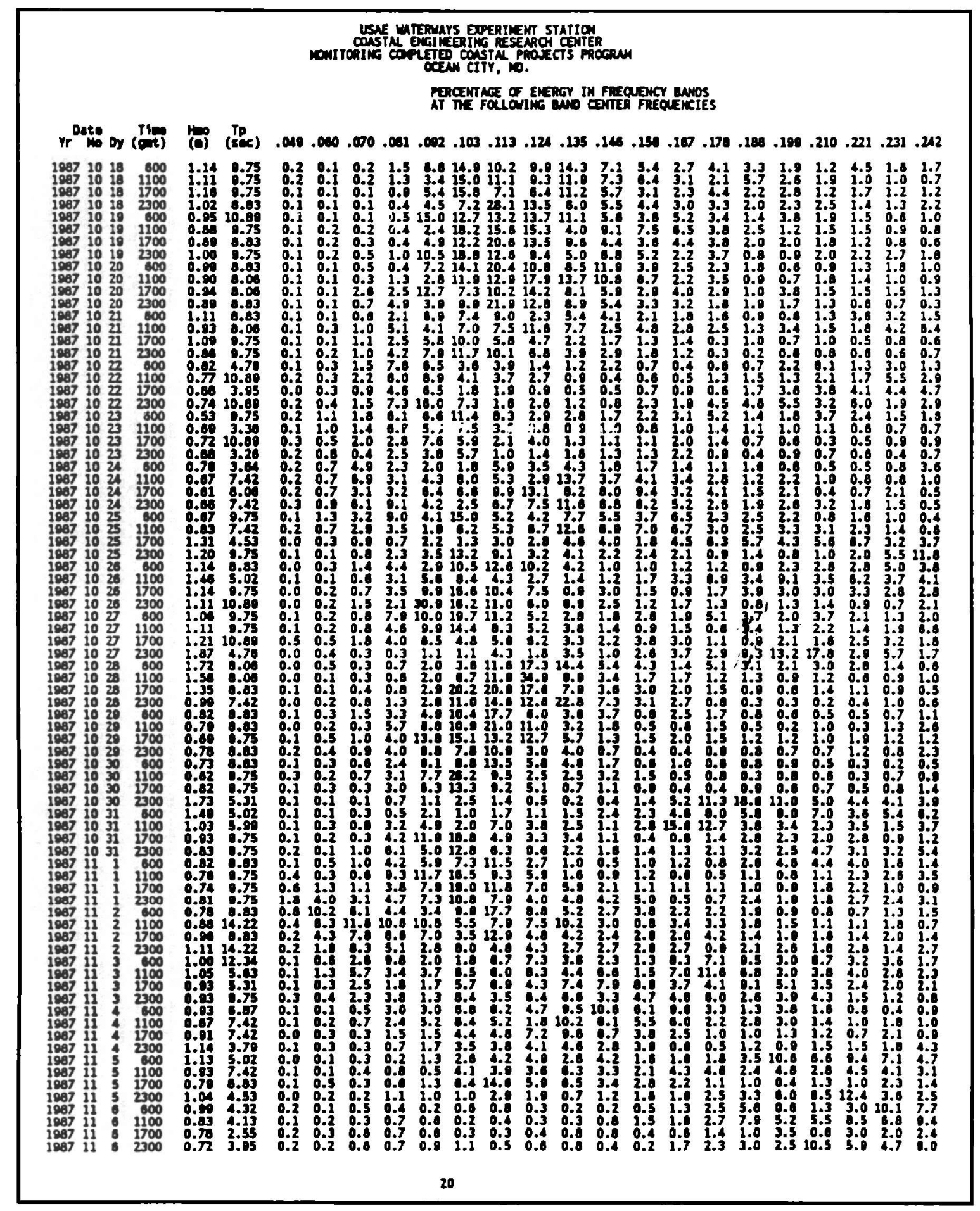




\section{Appendix B \\ PUV Wave and Current Gauge Data}

This appendix presents the wave data collected by the PUV directional wave gauge 635-12, gauge 40, which utilizes a Paros Scientific Quartz Pressure Sensor and a Marsh McBirney Electromagnetic Water Current Sensor. The gauge was deployed approximately $1 / 2$ mile offshore of Ocean City, MD, on 22 February 1987 and collected data through 12 May 1987. The data presented here is a time series analysis from 25 February 1987 through 11 May 1987. 


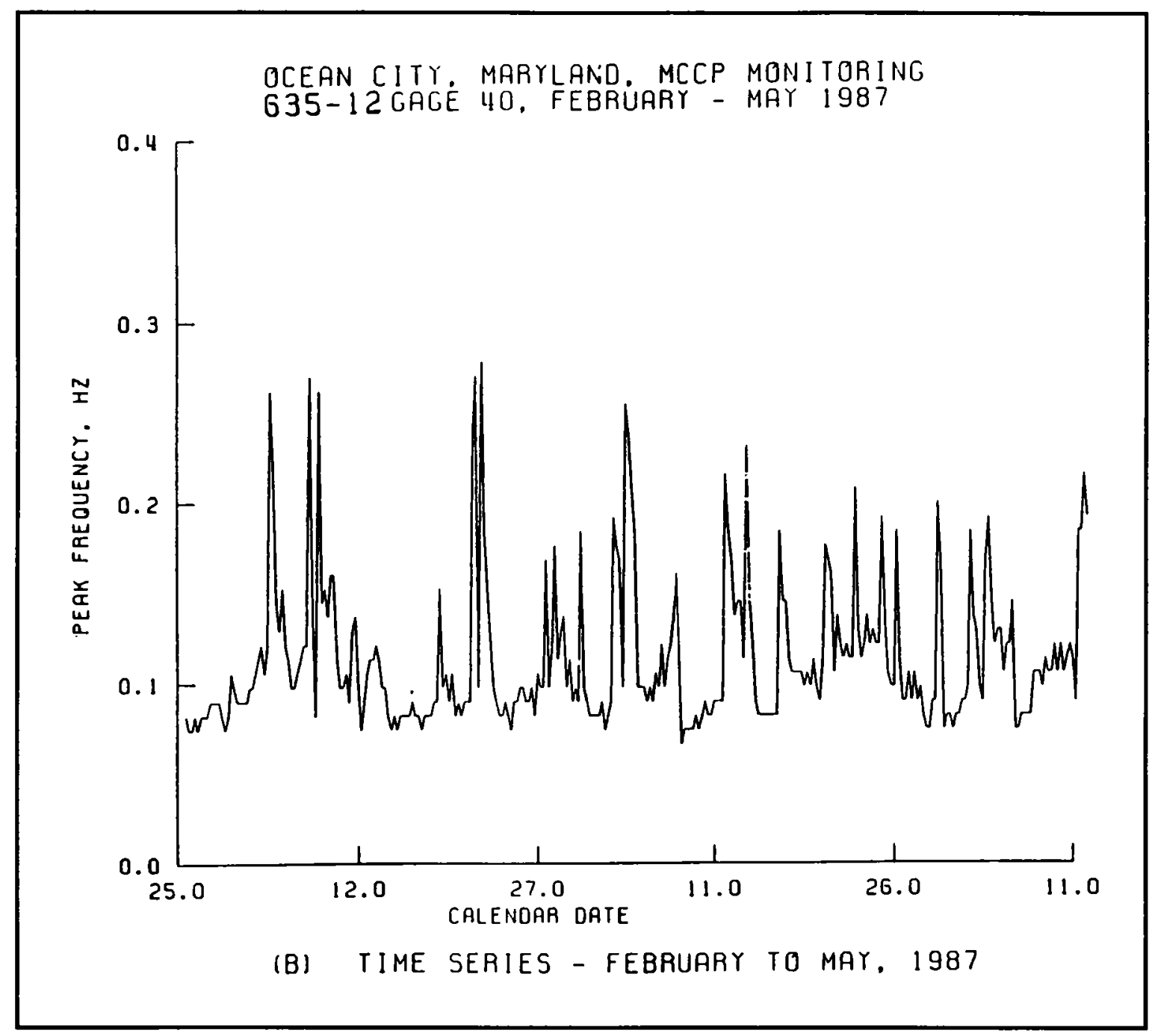




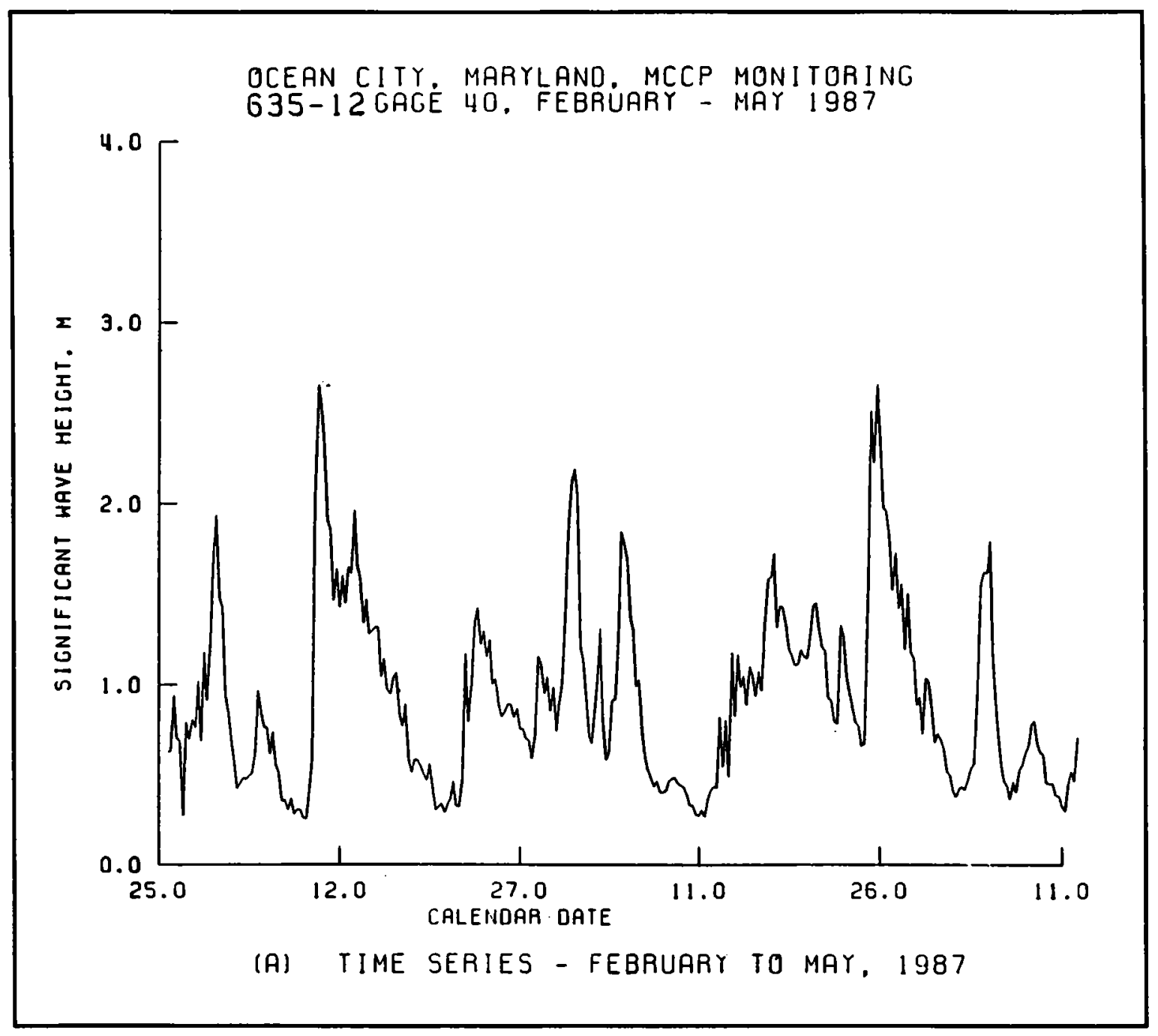




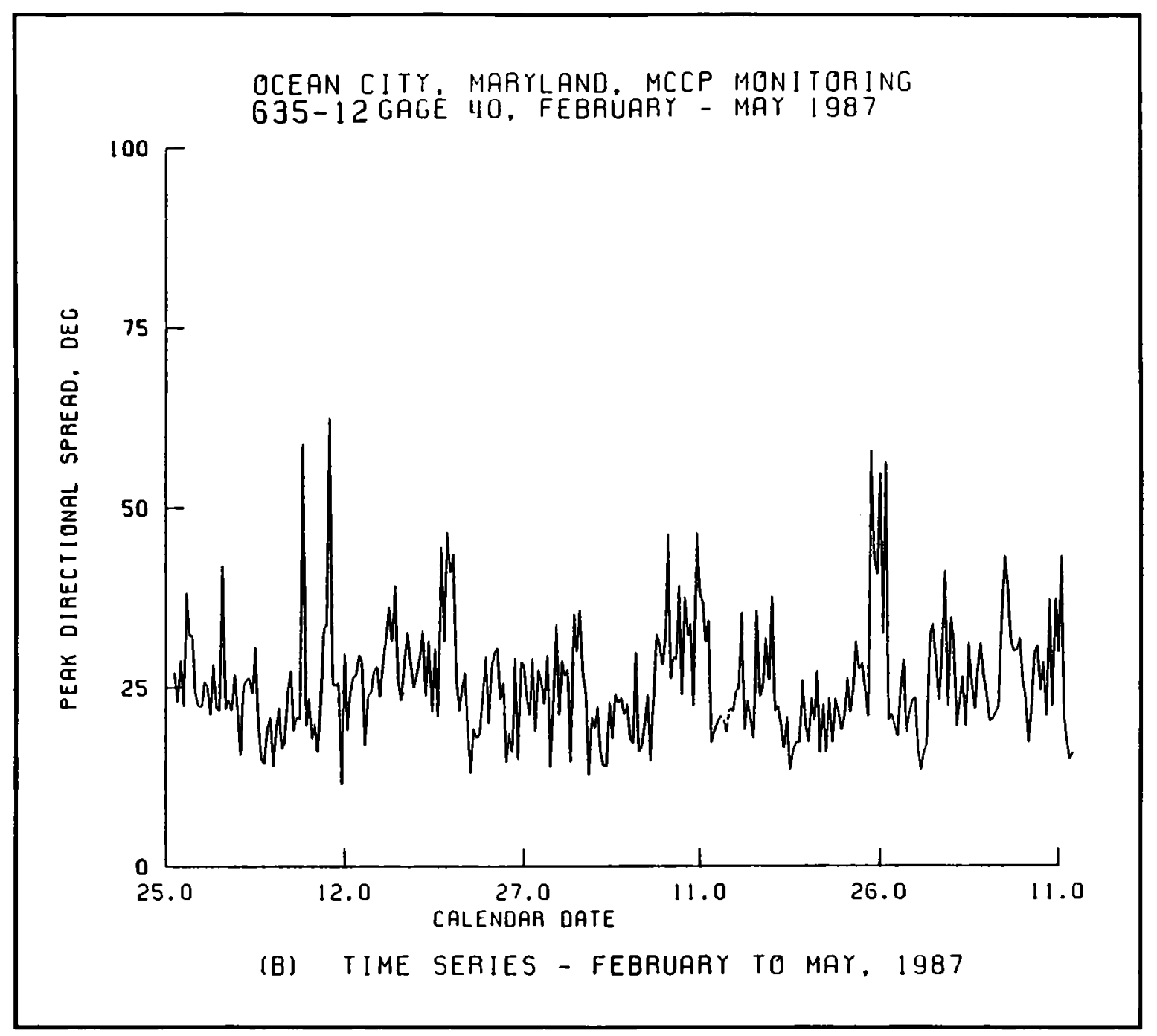




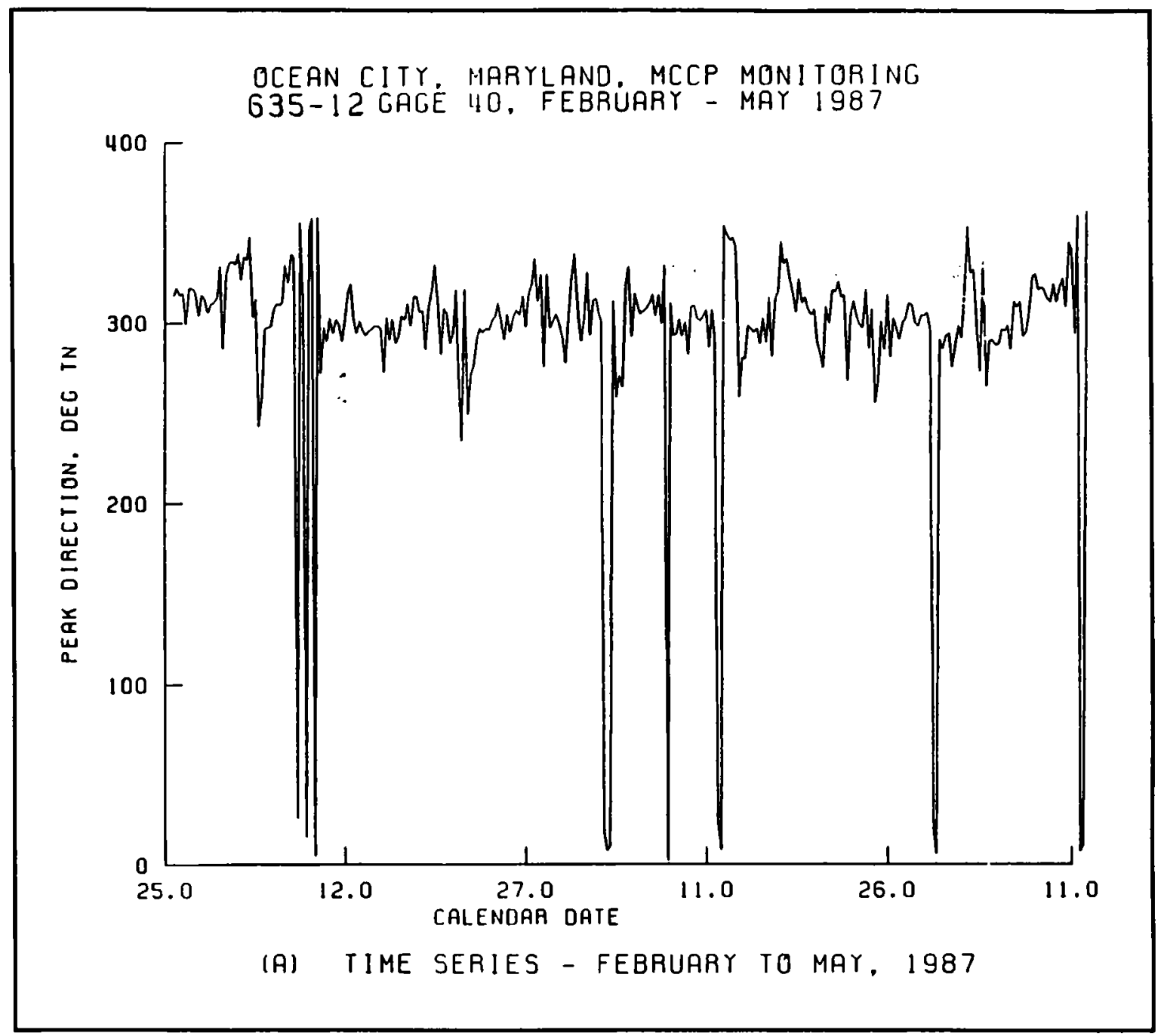




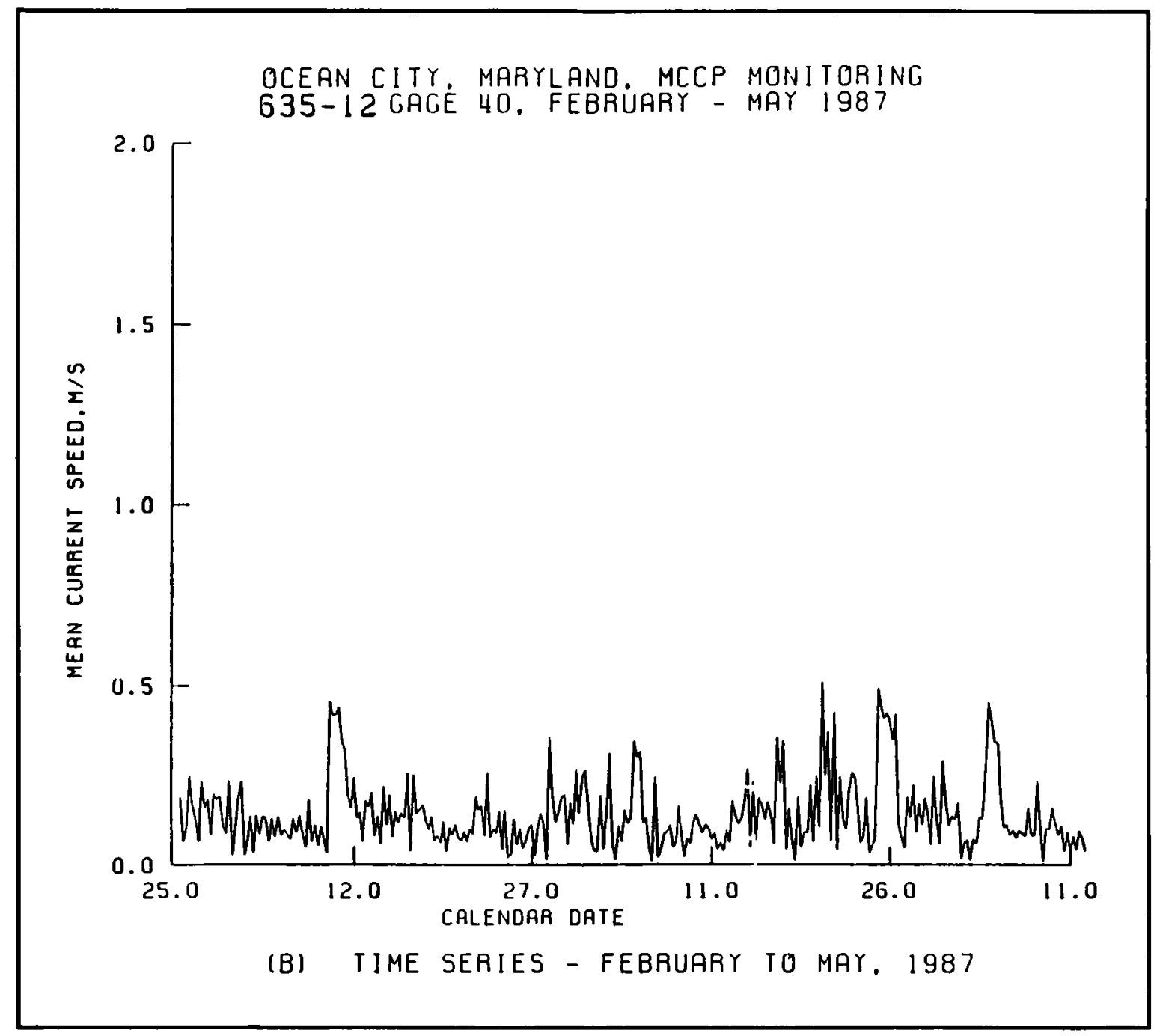




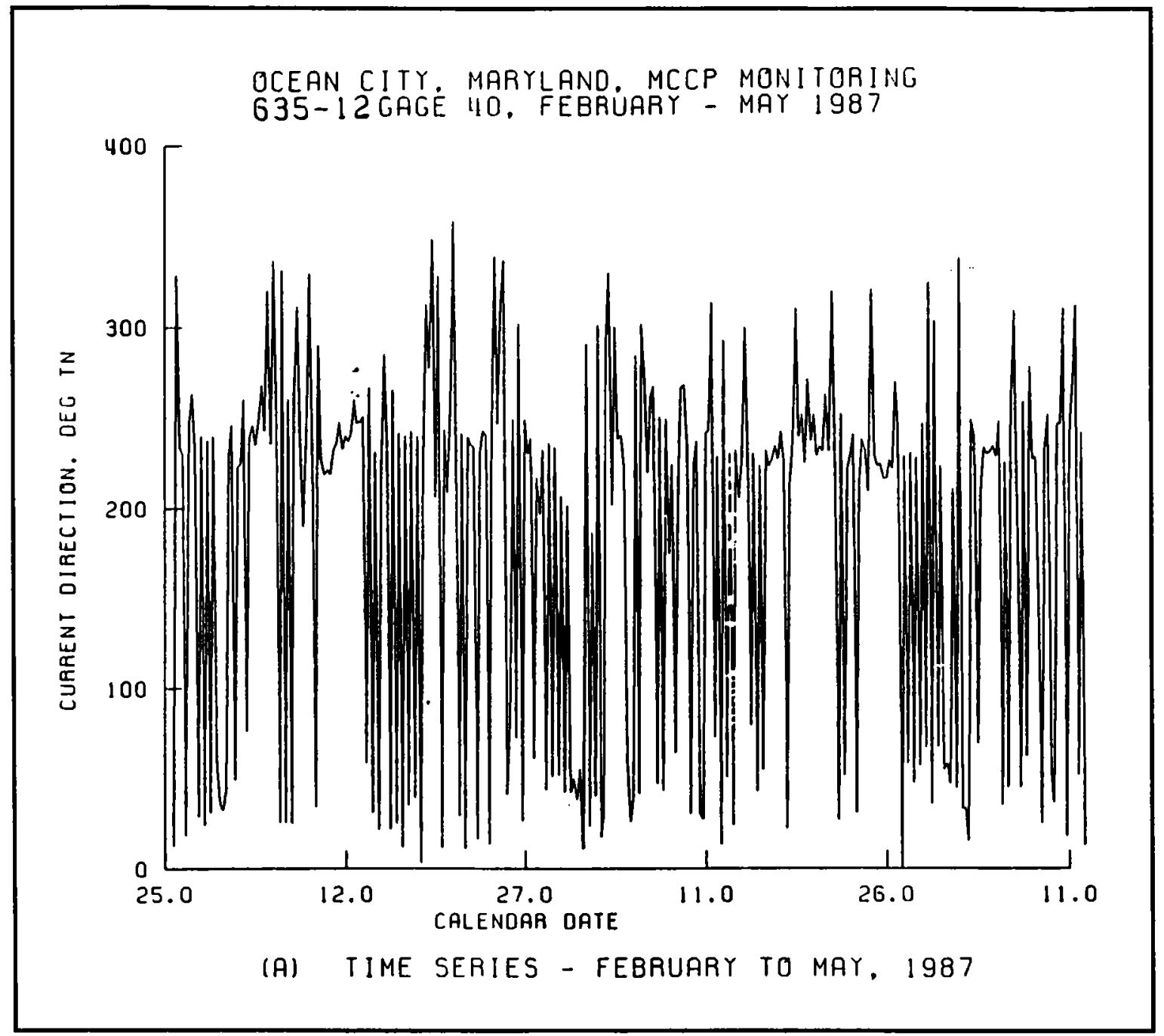




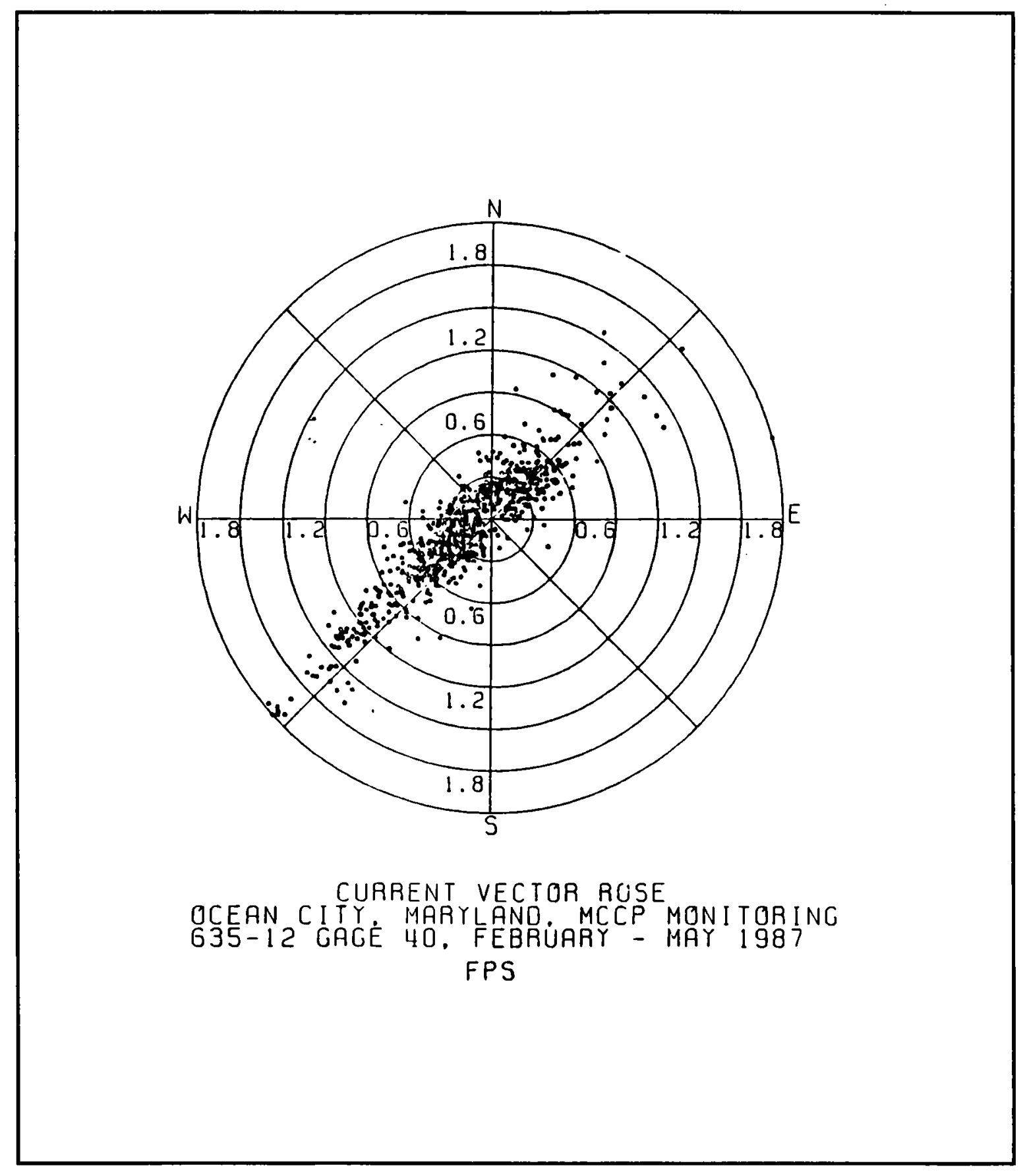


OCEAN CITY. MARYI.AND, MCCP MCNITURING

635-12 GAGÉ 40. FEBRUARY - MAY 1987

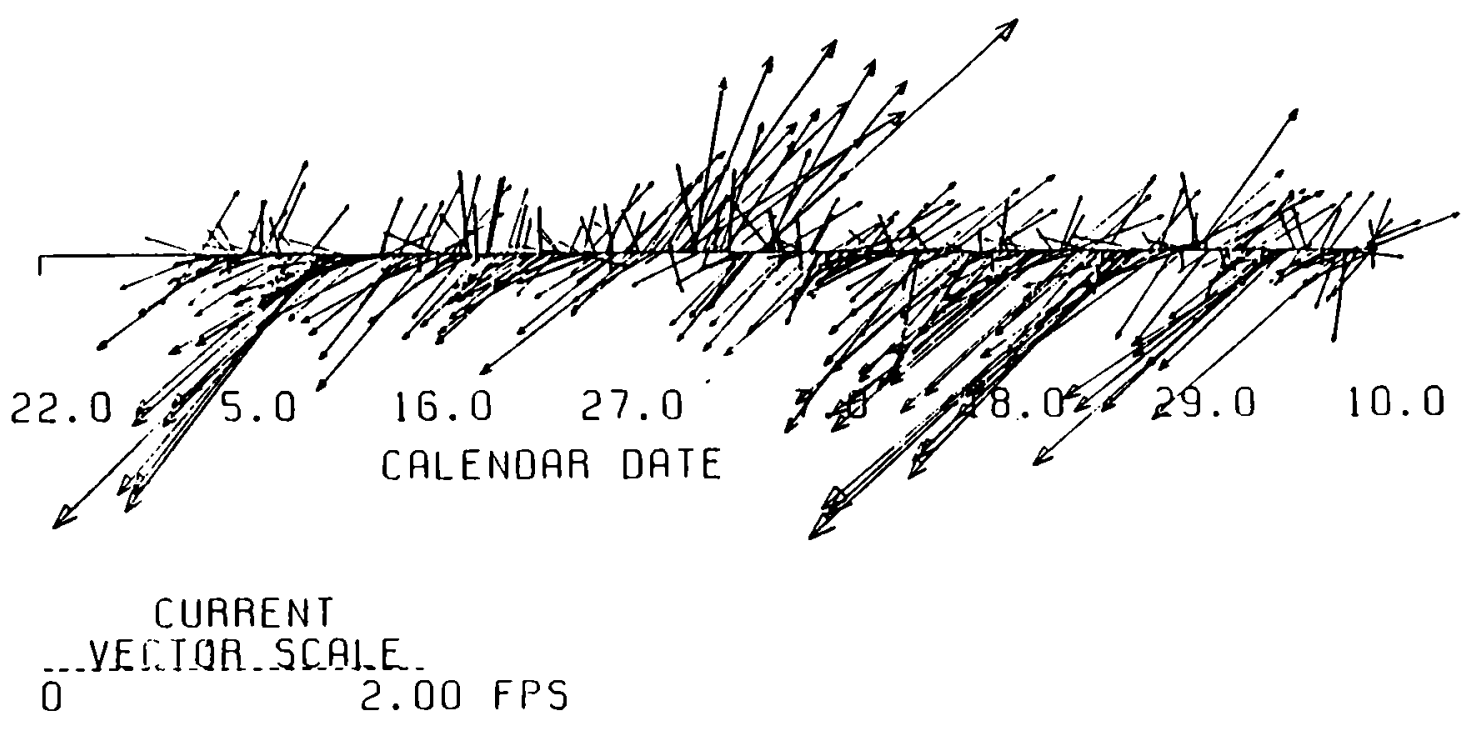





\section{Appendix C Profile Comparisons}

Profile survey data were collected at 15 sites along the beach south of the jetties. The profiles were surveyed to the -30 -ft NGVD contour to capture depth of closure. Four additional profiles were surveyed at the northern end of Assateague Island. The beach surveys are denoted by the prefix "AL" in the profile identifier, and the profiles located at the northern end of Assateague are denoted by "AB." Surveys of the profiles were conducted on June 1986, October 1986, August 1987, and January 1989. 


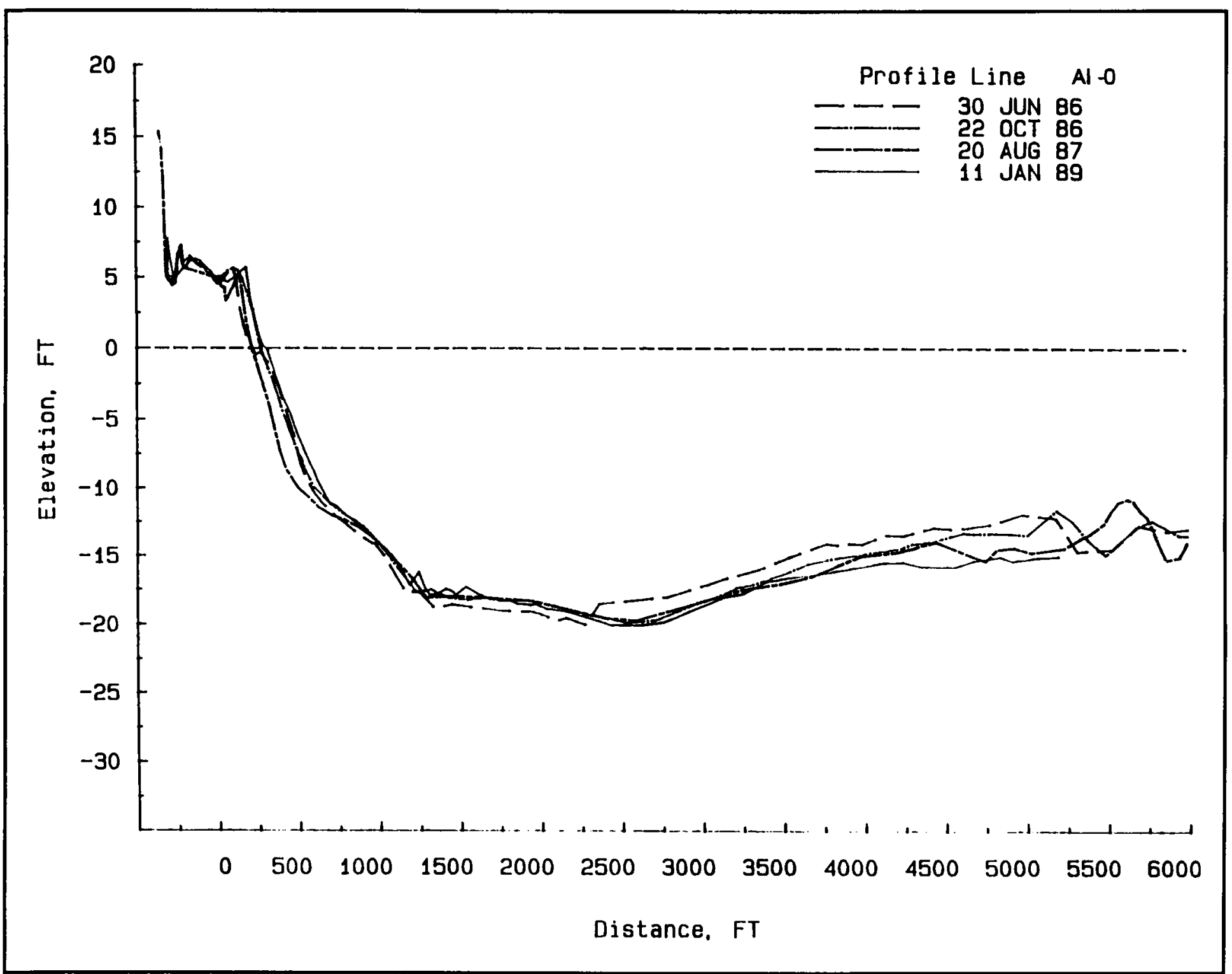




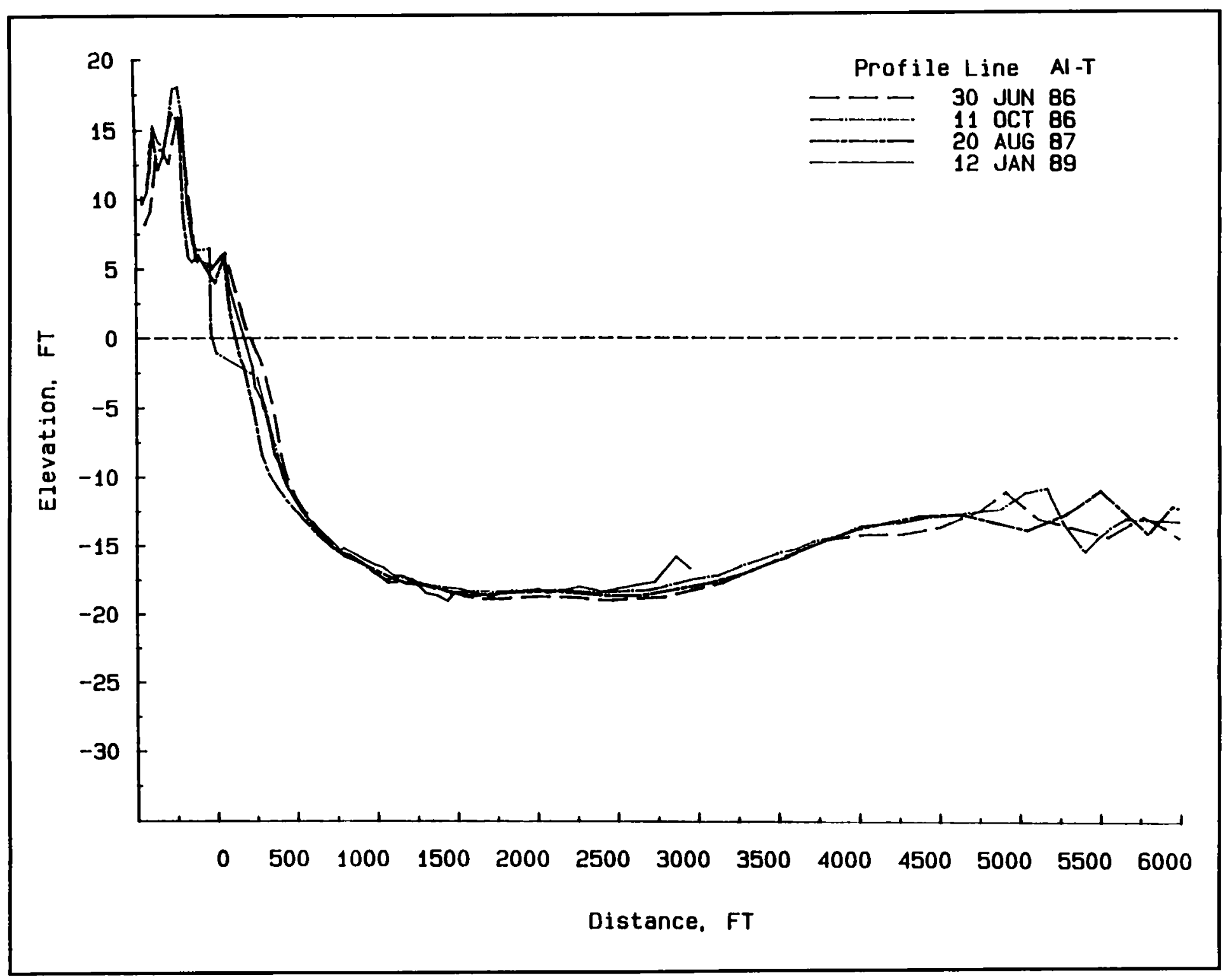




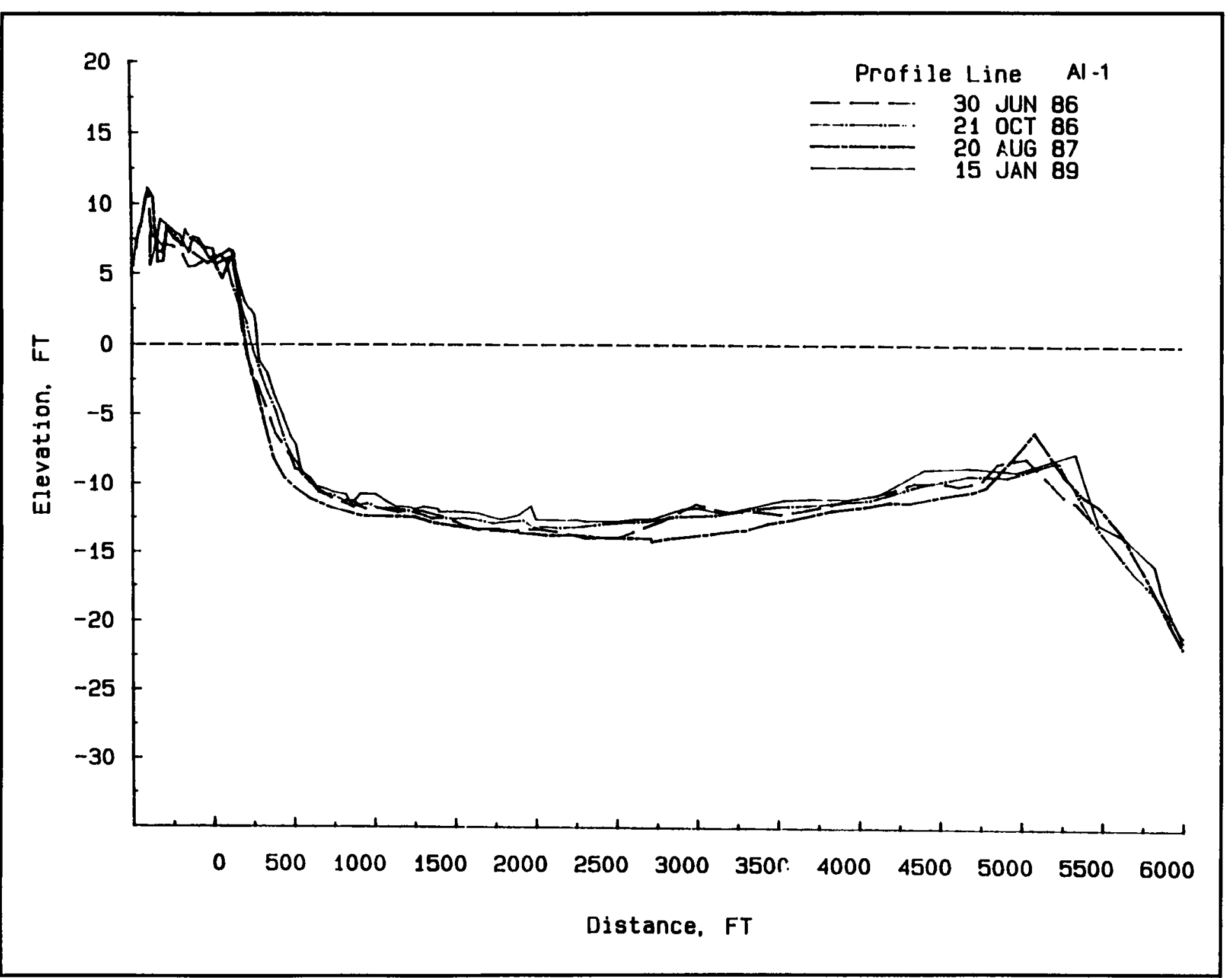




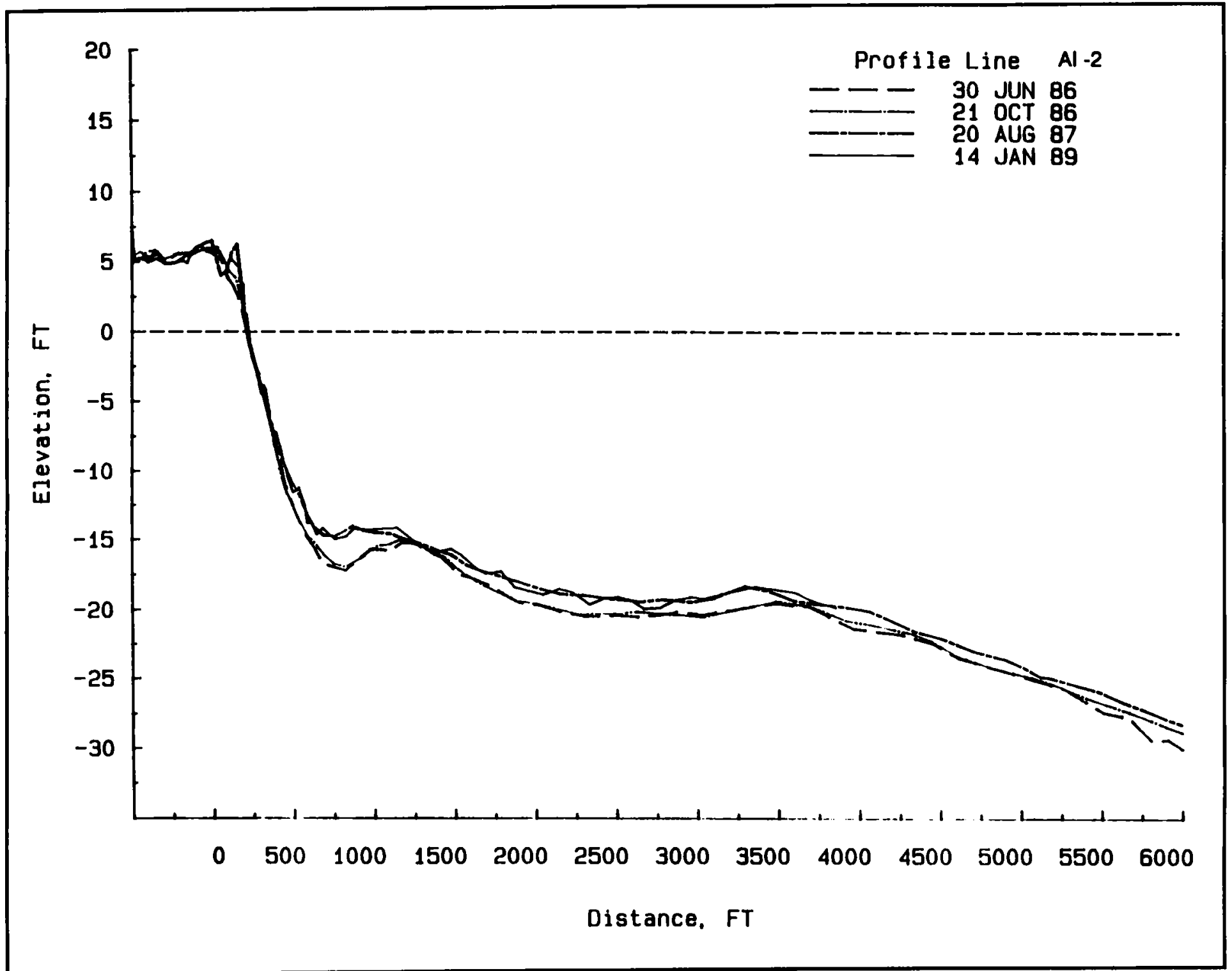




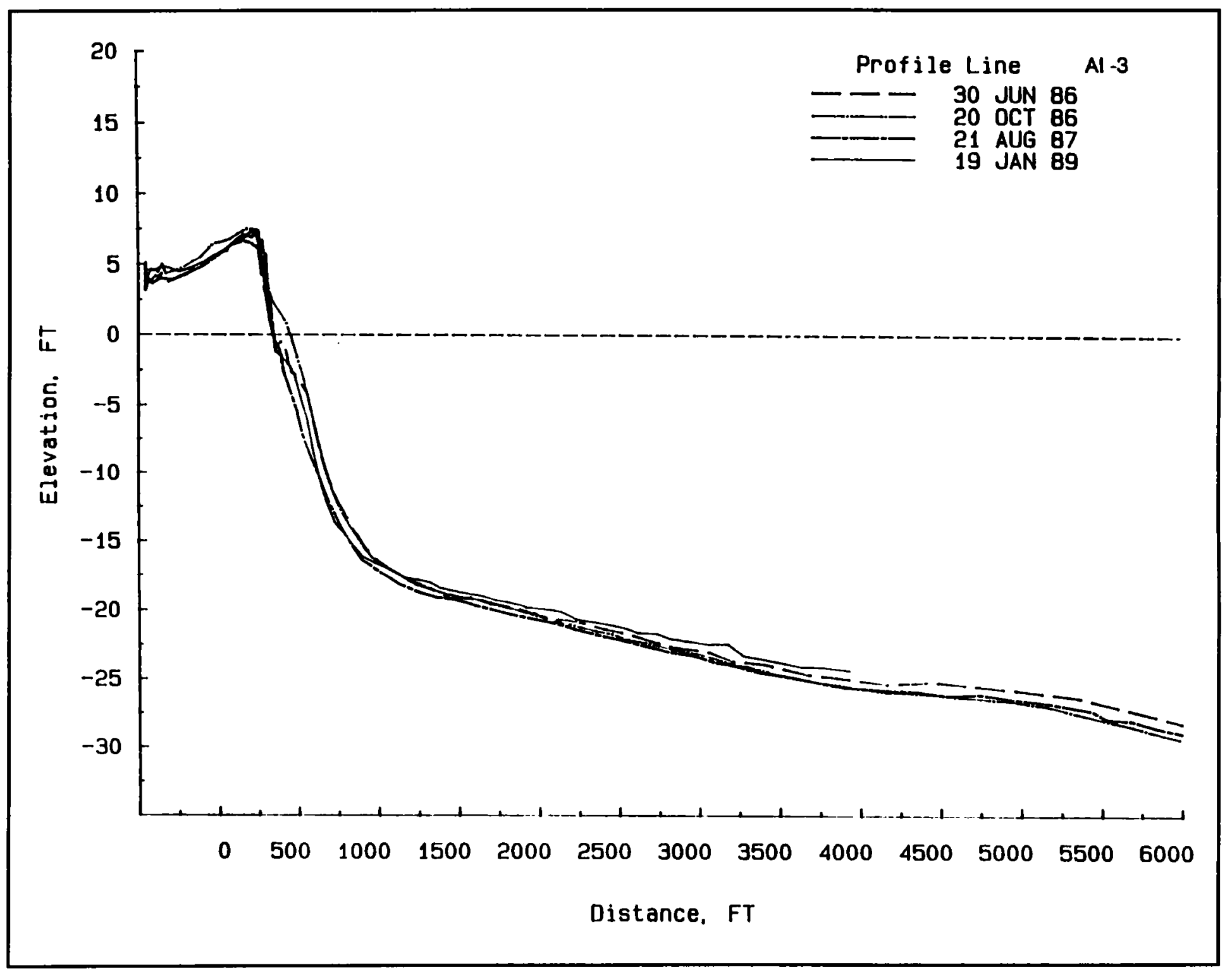




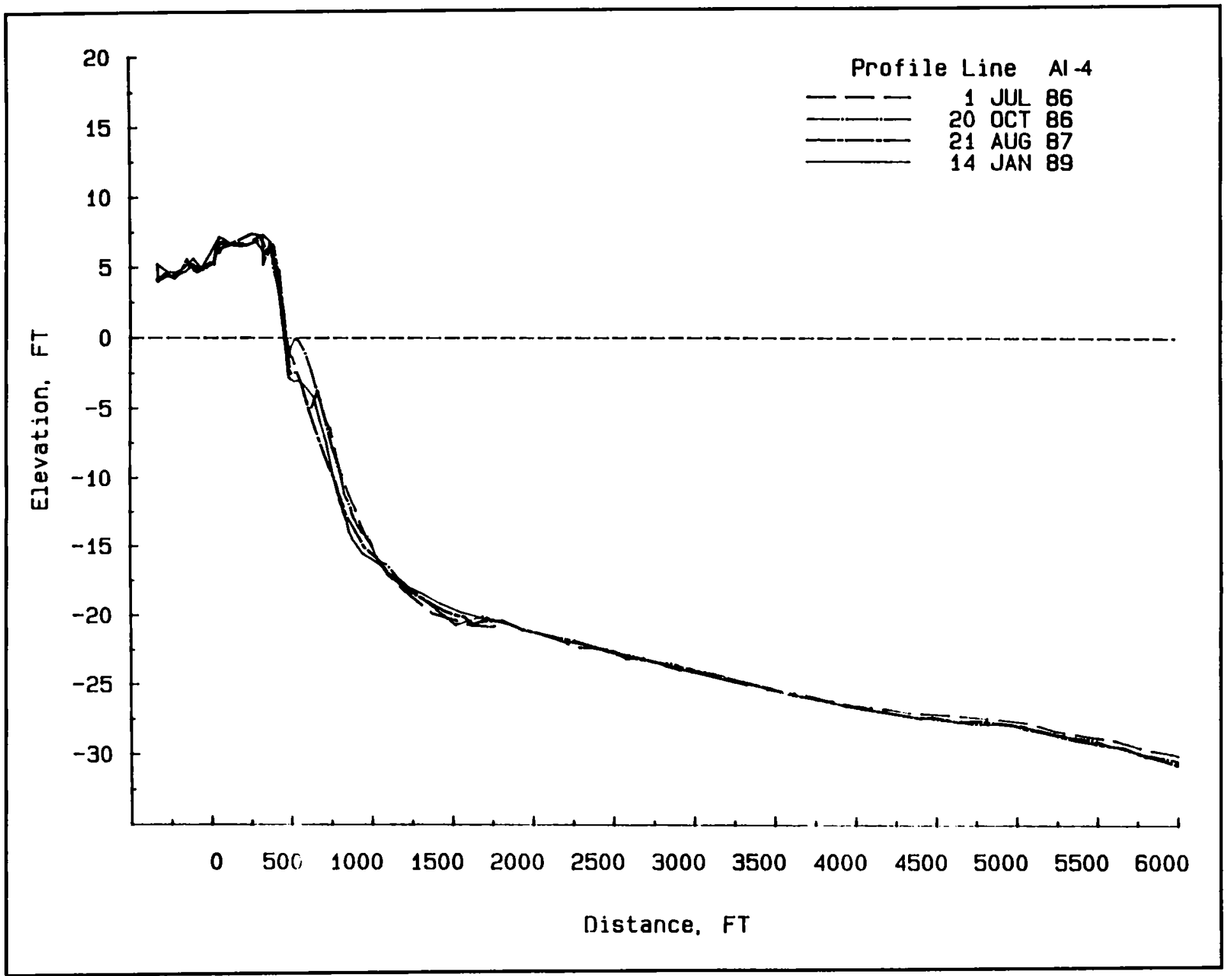




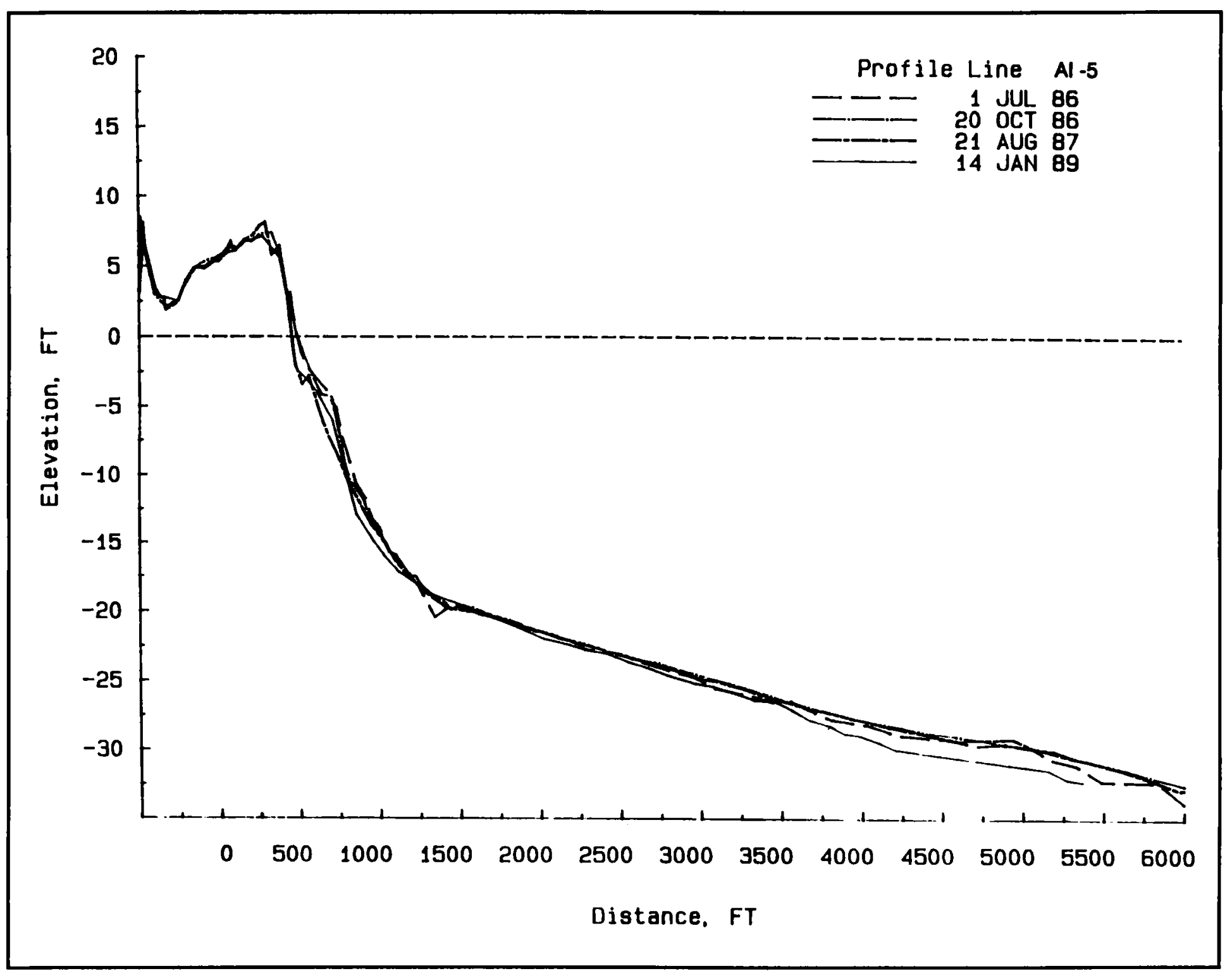




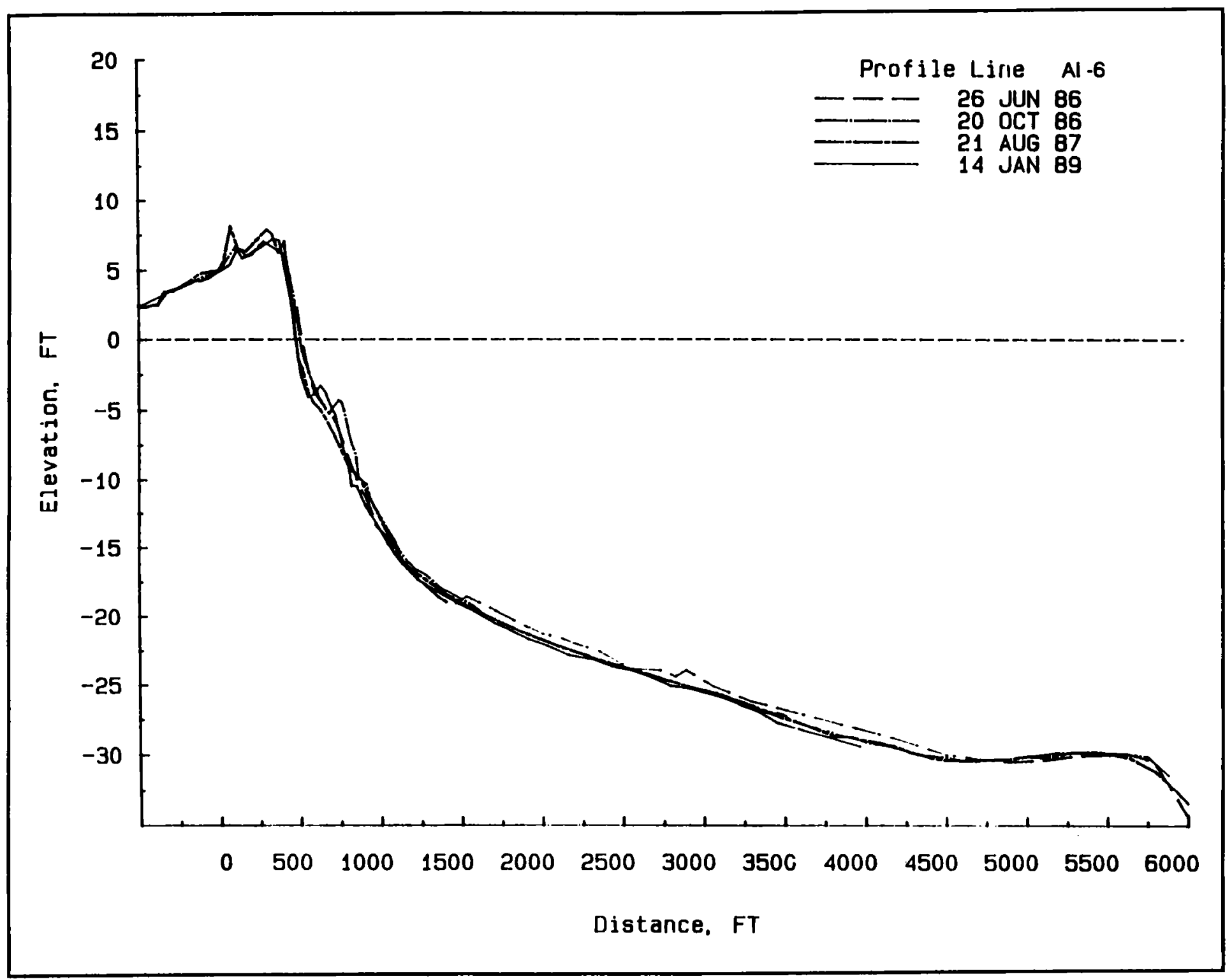


옹

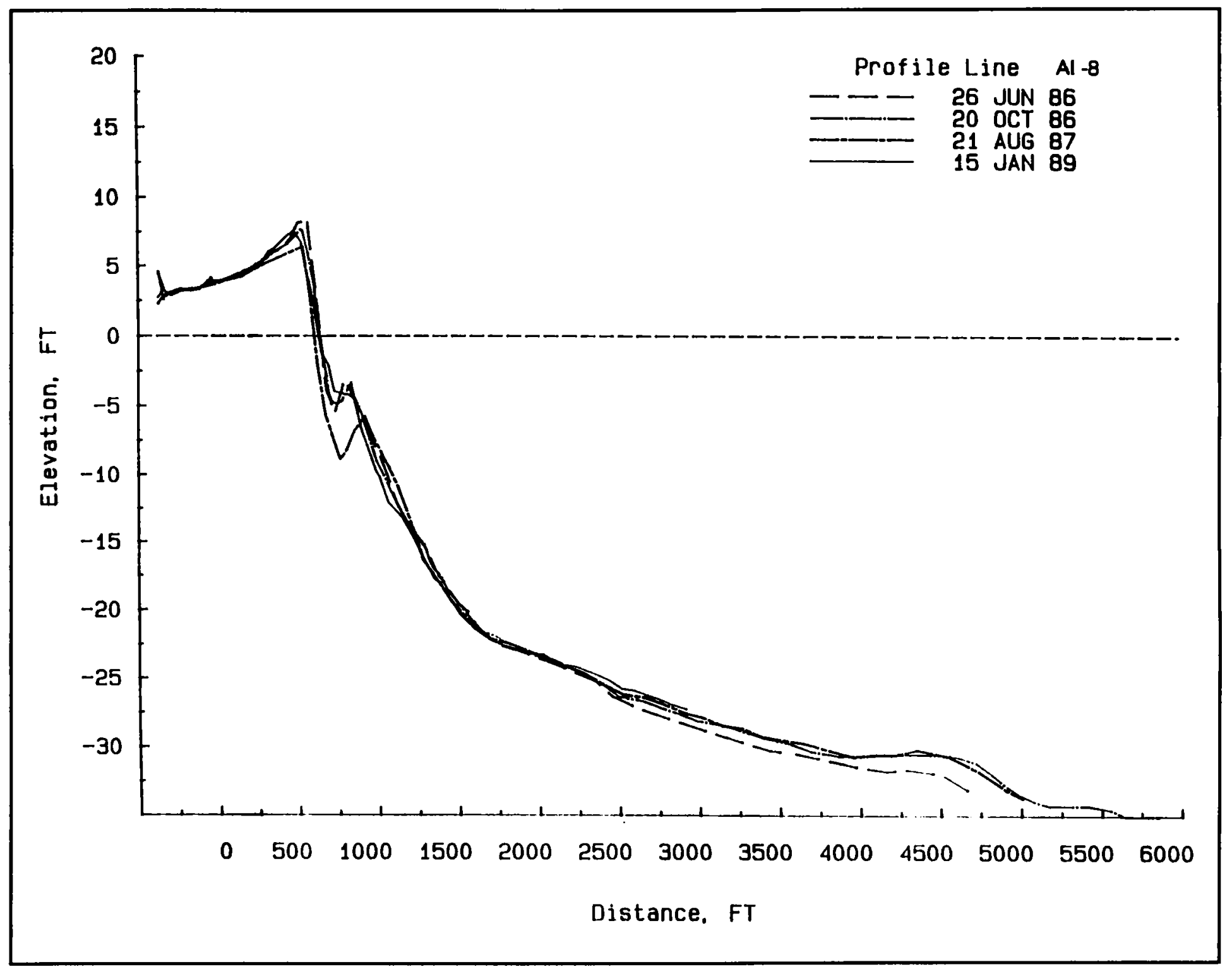




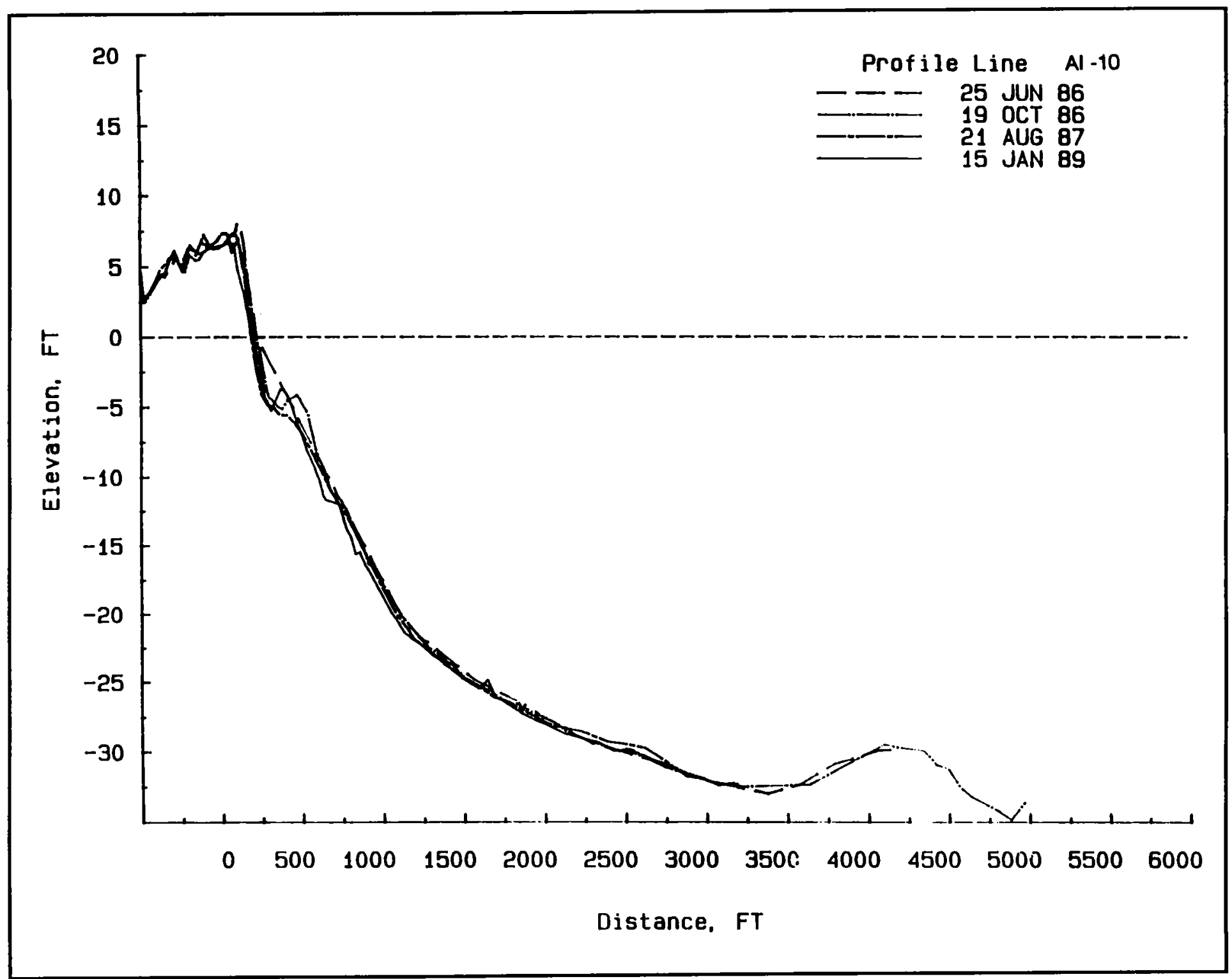




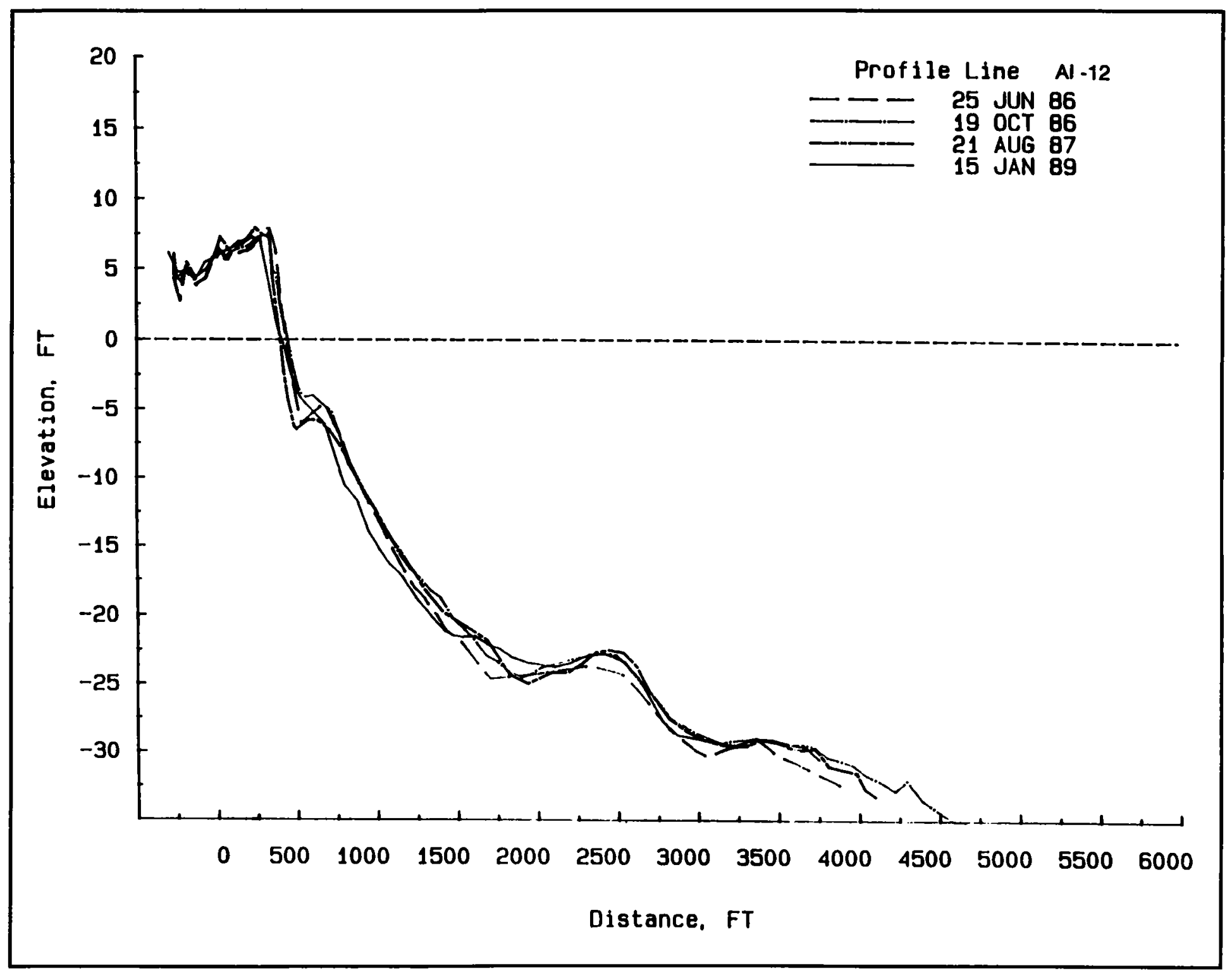




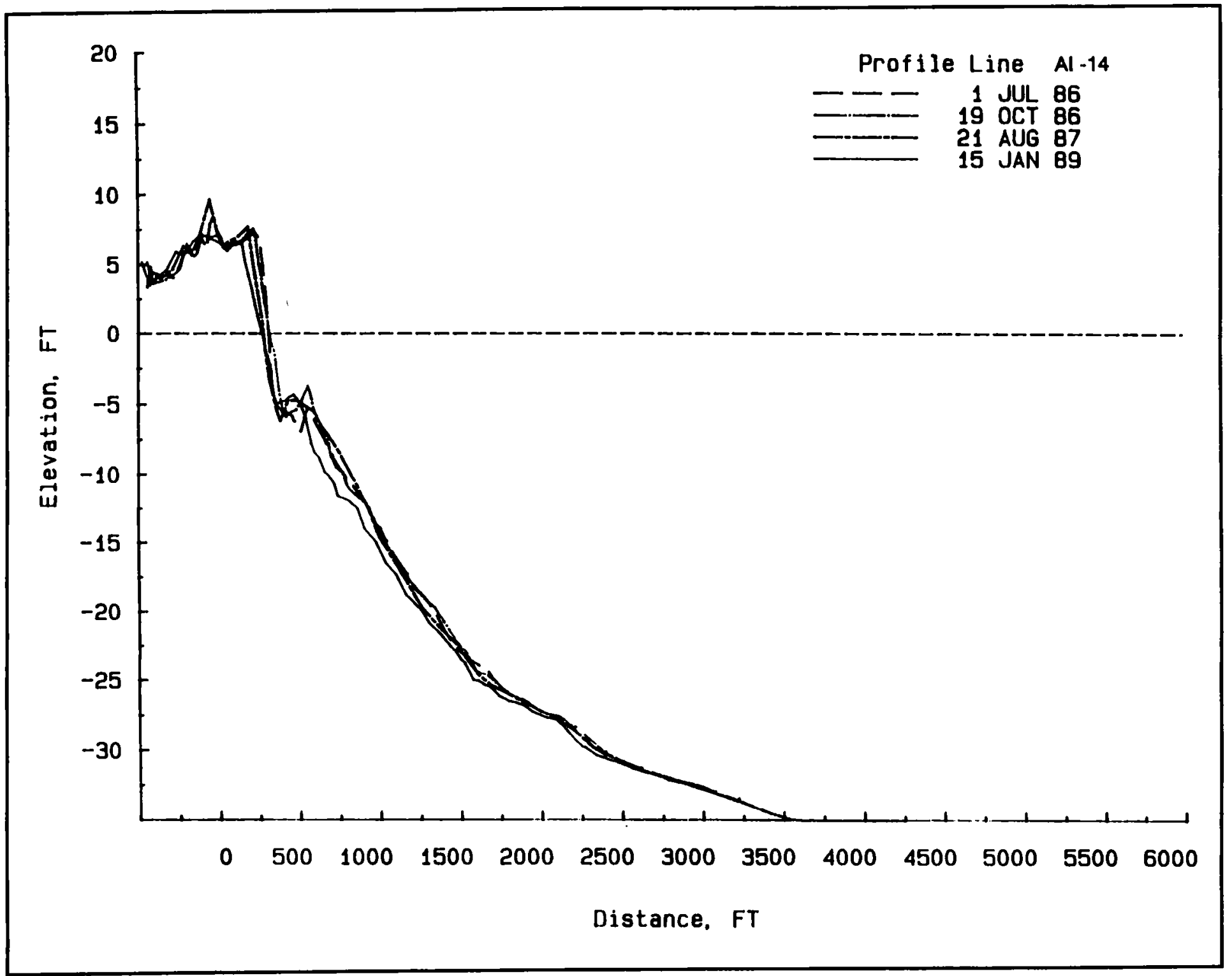




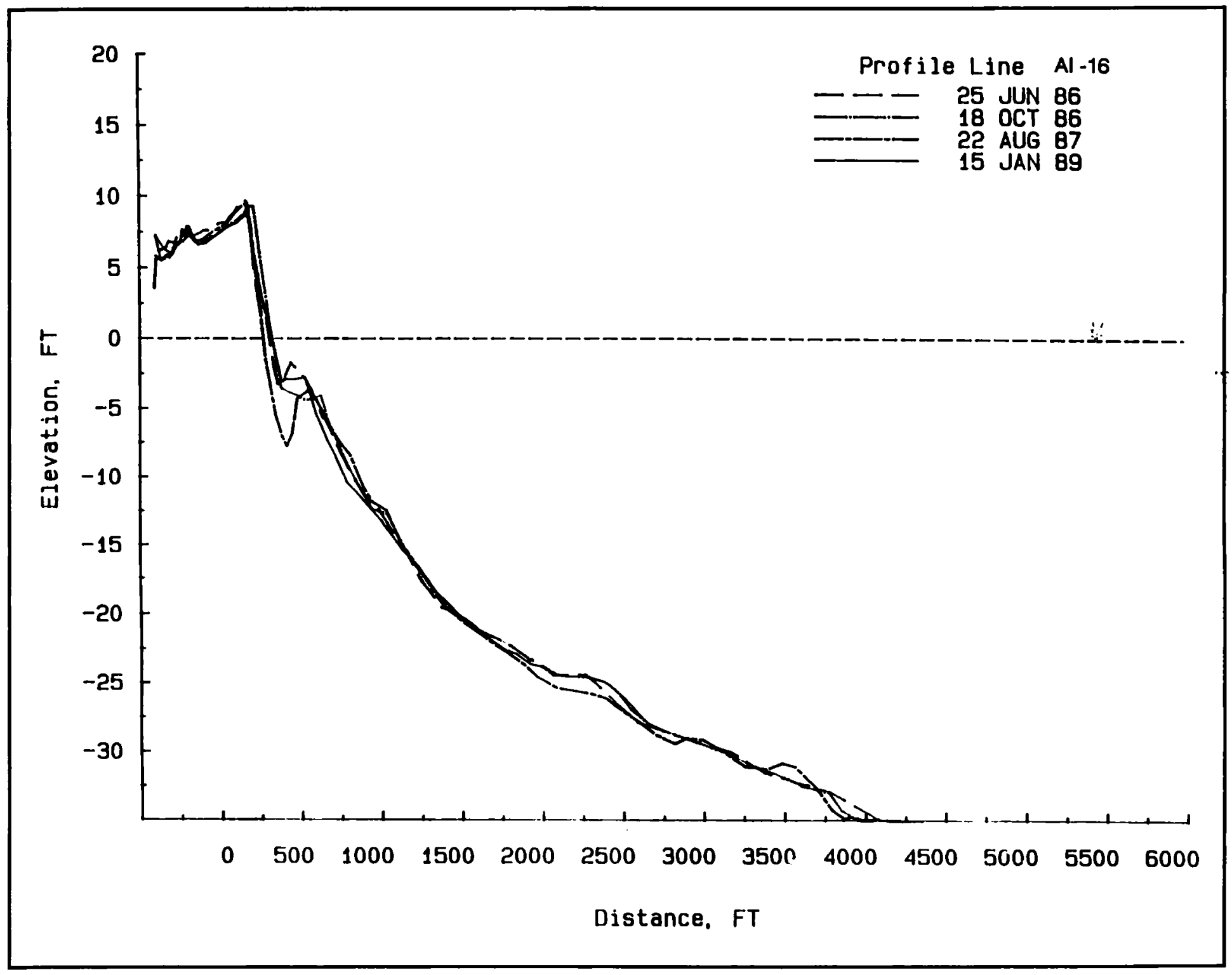




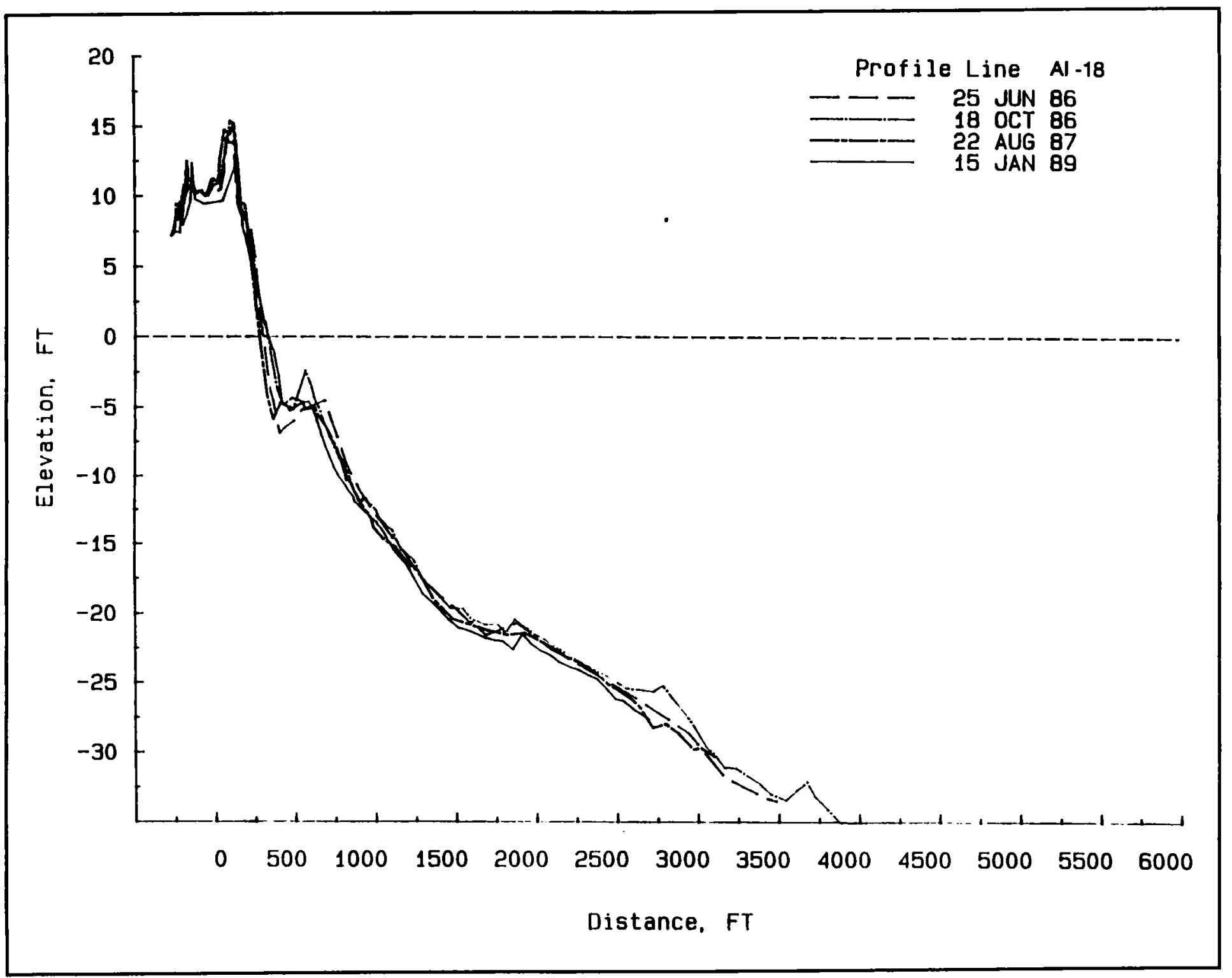

$\frac{\Omega}{v}$ 


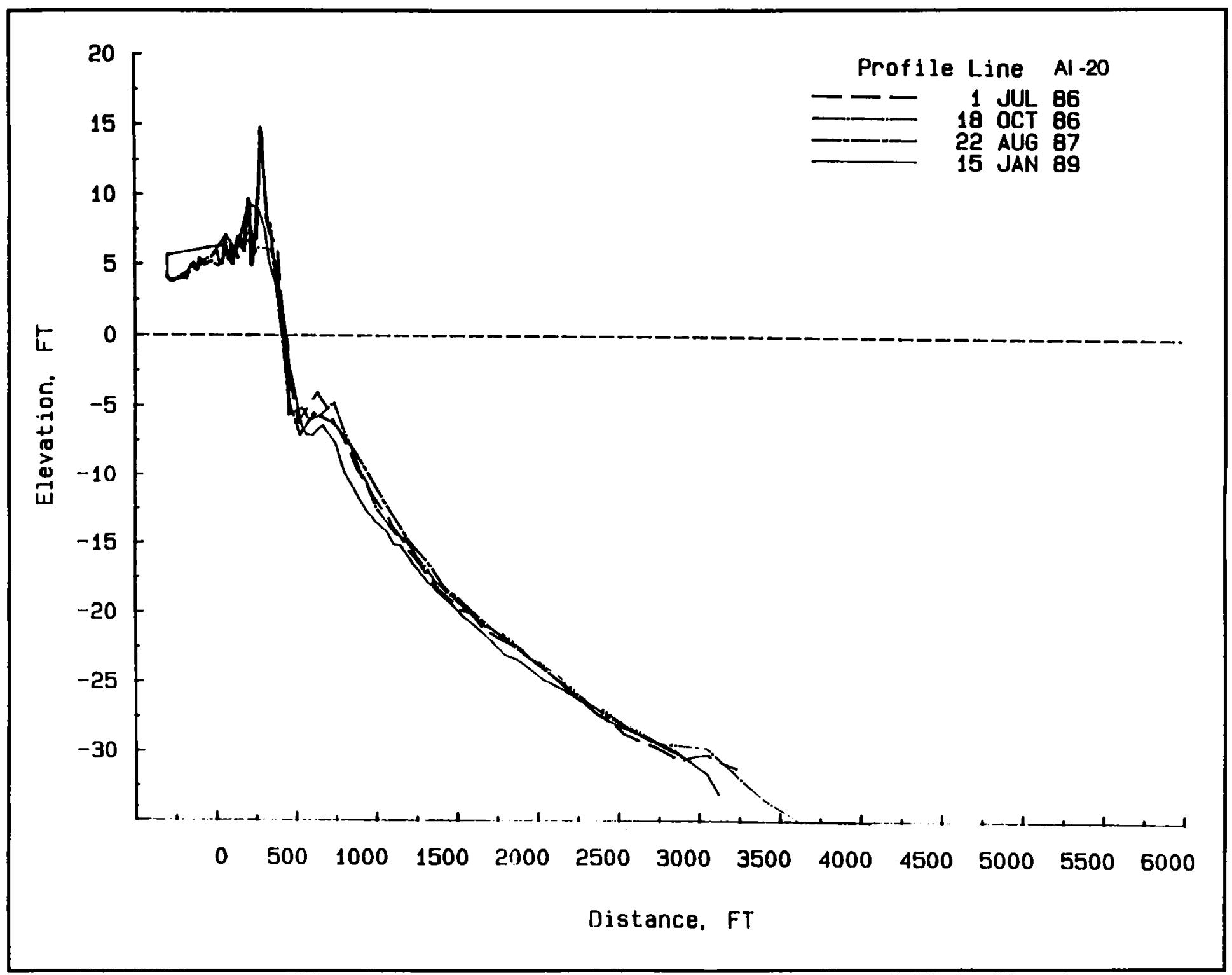




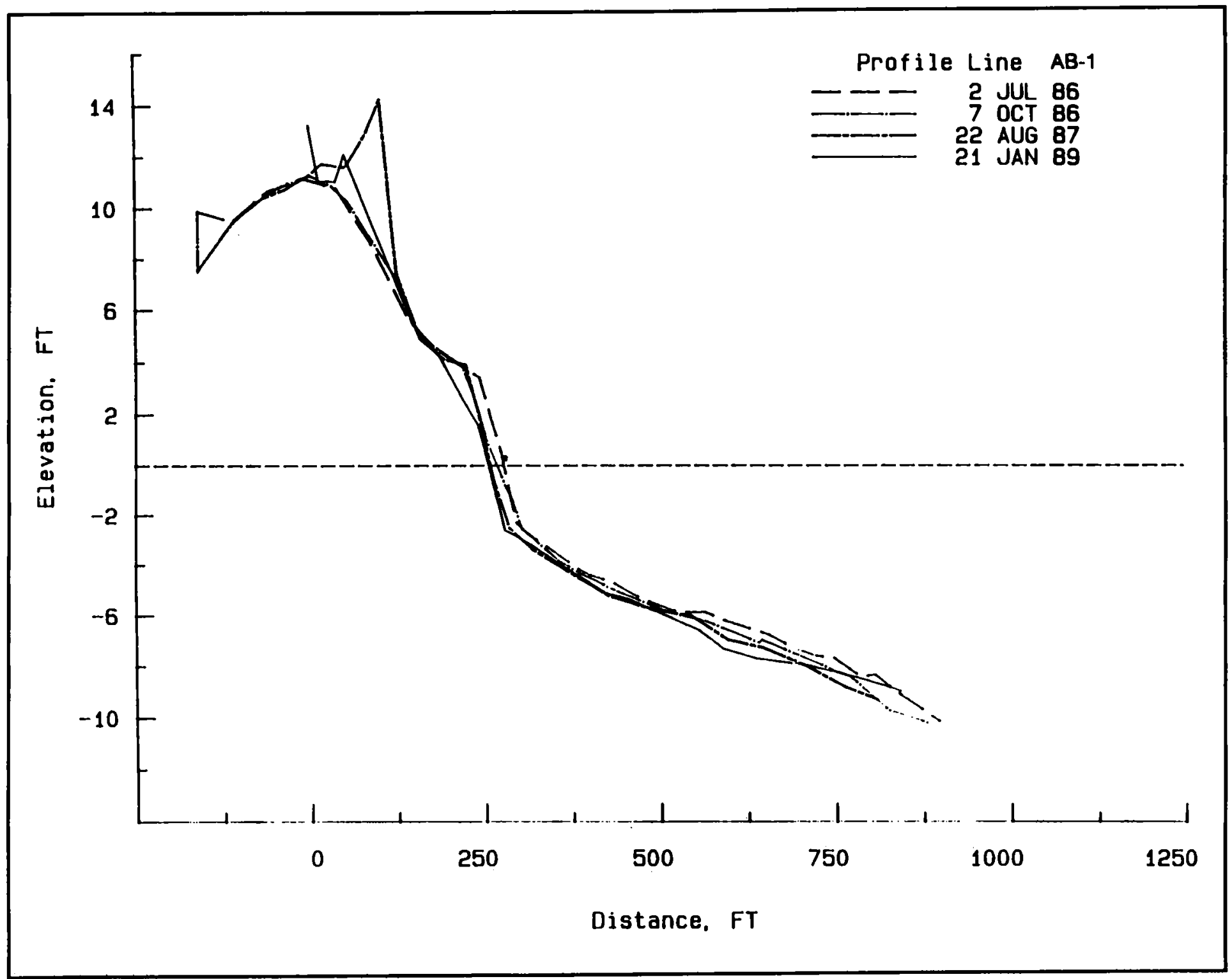



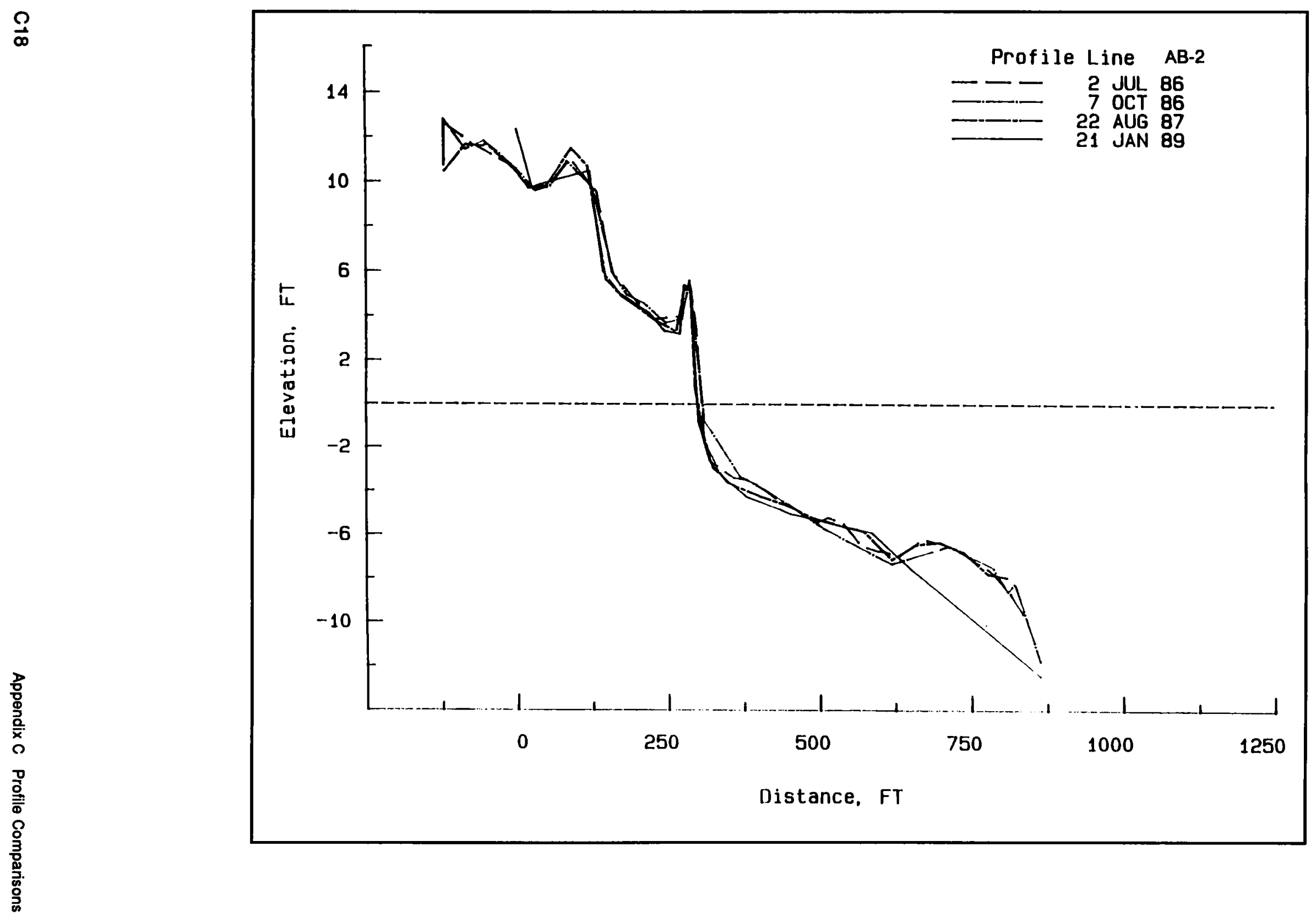


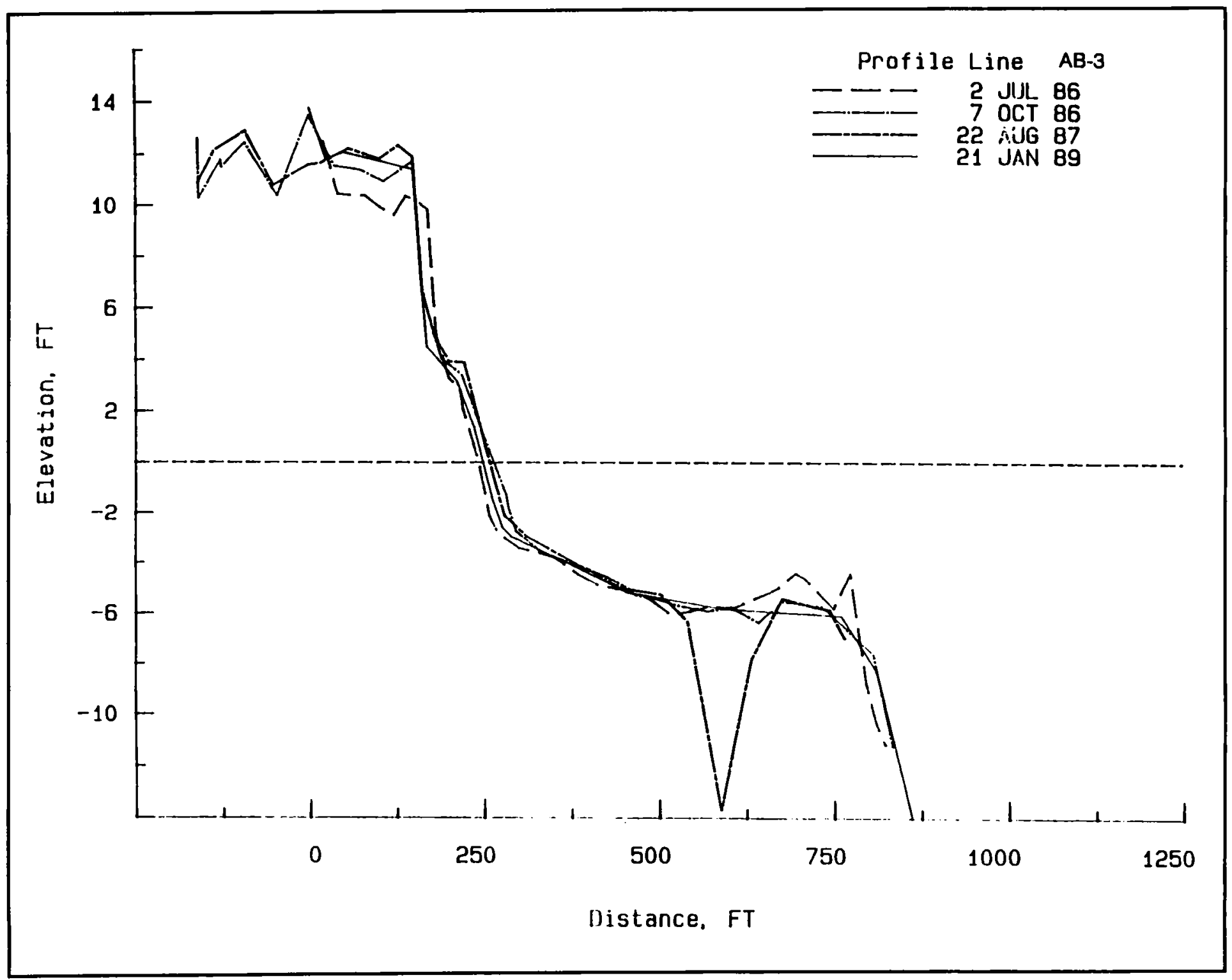




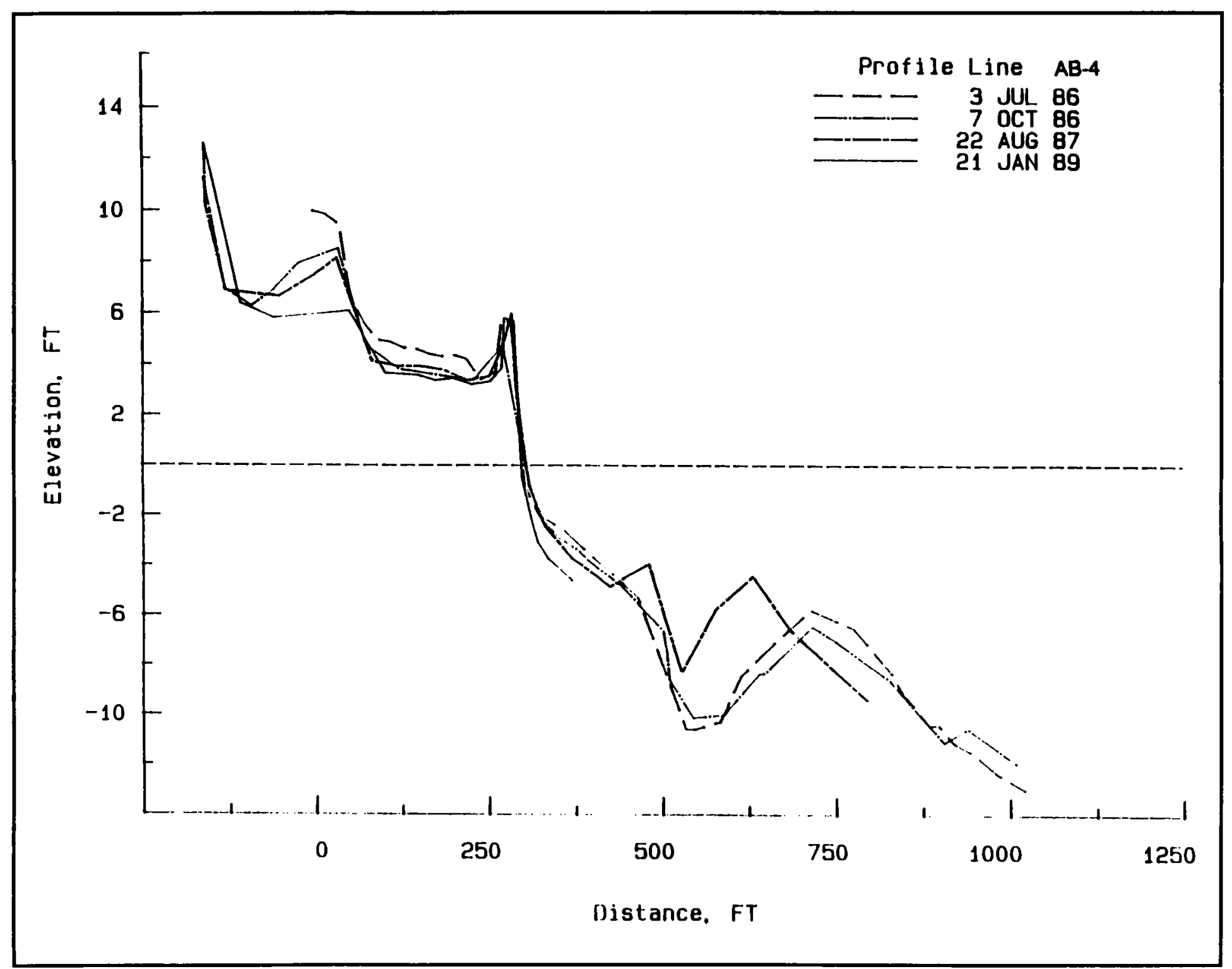




\section{Appendix D Shoreline Change Maps}

Shoreline change maps were prepared to evaluate the changes of the Atlantic Ocean shoreline and Ocean City Inlet shoreline of the northern end of Assateague Island. A field survey of the northern end of Assateague Island was conducted on 6 and 7 March 1990 and was used as the base map. This survey was conducted using a Topcon HA-3 Data Collector and GTS3 Total Survey Station. The baseline traverse set up for the profile surveys was used for this survey.

The survey data file was transferred directly from the data collector into an AutoCad Version 10 computer file. The data were then reduced and contoured using DCA engineering software, and base maps were prepared at scales of $1 \mathrm{in} .=100 \mathrm{ft}$ and $1 \mathrm{in} .=200 \mathrm{ft}$. 



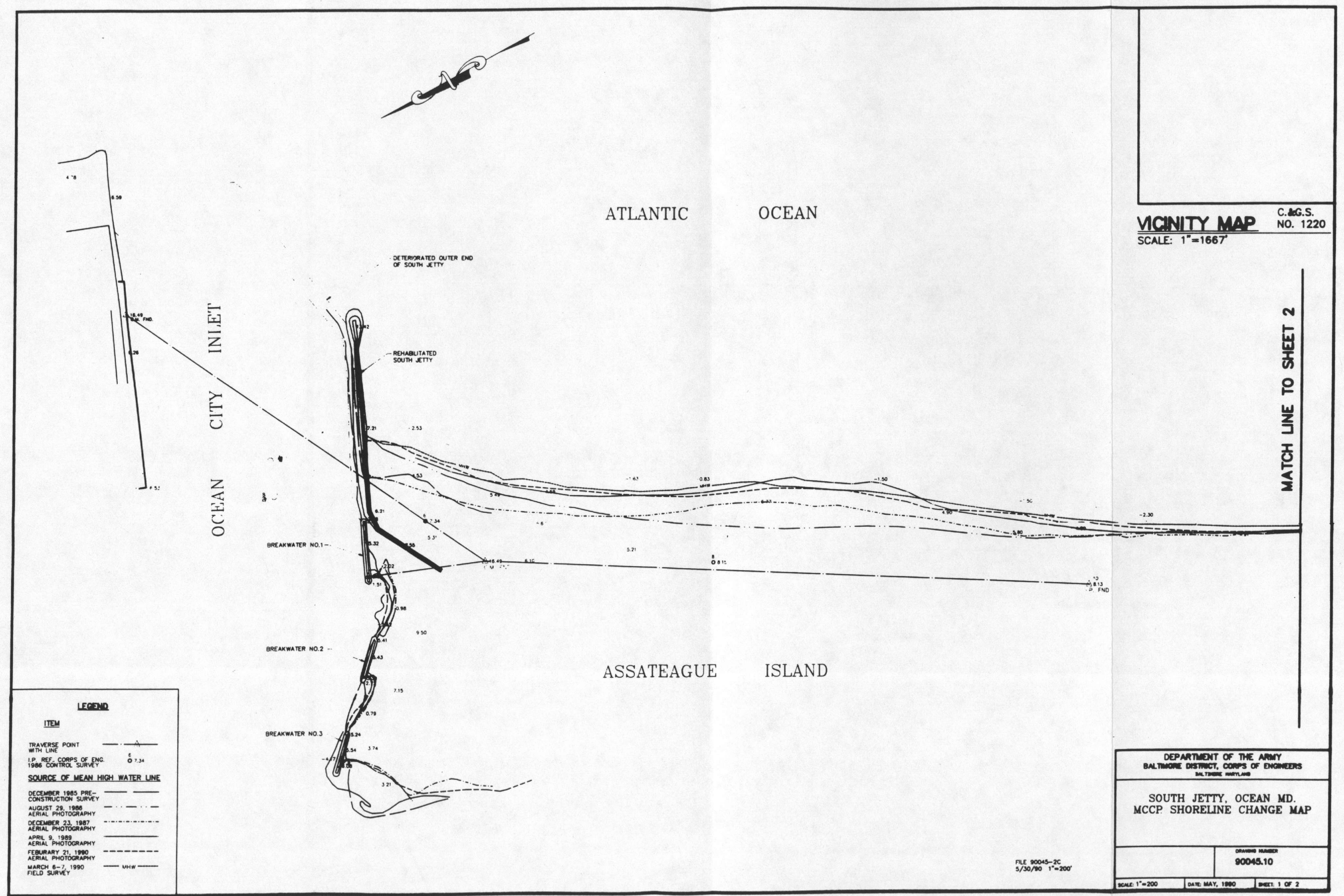





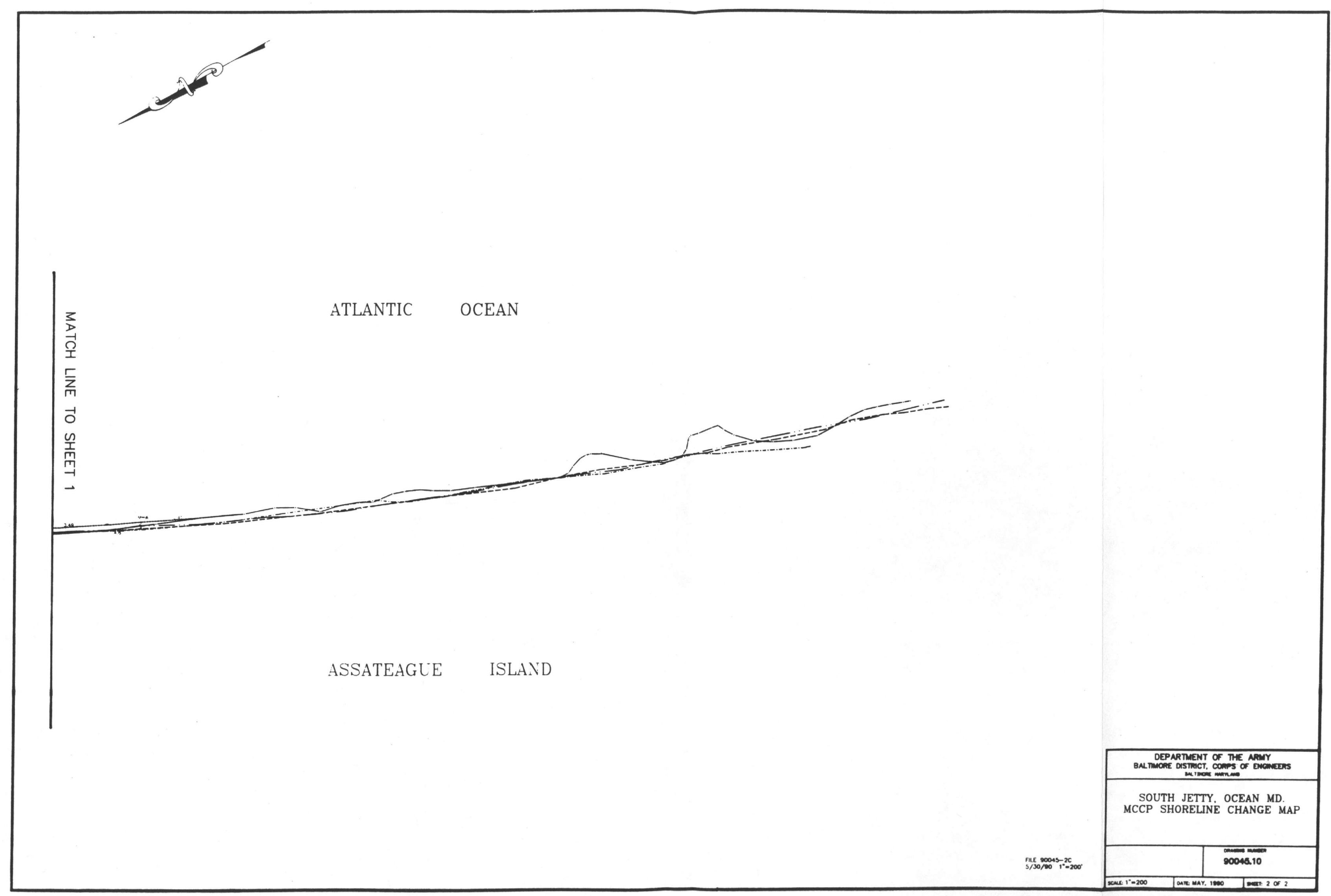





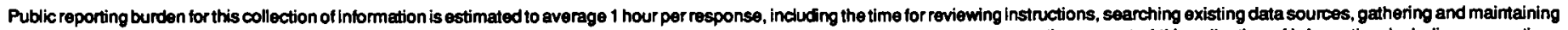

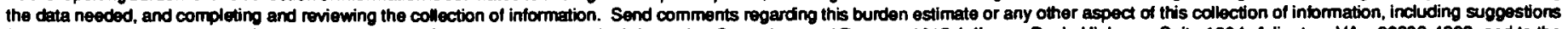

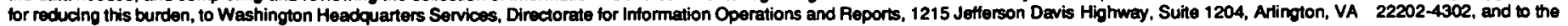
Office of Management and Budget, Paperwork Rectuction Project (0704-0188), Washington, DC 20503.

\begin{tabular}{|c|c|c|}
\hline 1. AGENCY USE ONLY (Leave blank) & $\begin{array}{l}\text { 2. REPORT DATE } \\
\text { March } 1994\end{array}$ & $\begin{array}{l}\text { 3. REPORT TYPE AND DATES COVERED } \\
\text { Final report }\end{array}$ \\
\hline
\end{tabular}

4. ITLE AND SUBTITLE

Rehabilitation of the South Jetty, Ocean City, Maryland

5. FUNDING NUMBERS

6. AUTHOR(S)

Gregory P. Bass, Edward T. Fulford, Steven G. Underwood, Larry E. Parson

7. PERFORMMNG ORGANIZATION NAME(S) AND ADDRESS(ES)

U.S. Army Engineer District, Baltimore, Baltimore, MD 21203-1715;

Andrews, Miller, \& Assoc., Inc., Cambridge, MD 21613;

U.S. Army Engineer Waterways Experiment Station, Coastal Engineering Research

Center, 3909 Halls Ferry Road, Vicksburg, MS 39180-6199

9. SPONSORINGMONITORING AGENCY NAME(S) AND ADDRESS(ES)

8. PERForming ORGANIZATION REPORT NUMBER

Technical Report CERC-94-6

10. SPONSORING/MONITORING

AGENCY REPORT NUMBER

11. SUPPLEMENTARY NOTES

Available from National Technical Information Service, 5285 Port Royal Road, Springfield, VA 22161.

12a. DISTRIBUTIONAVAILABILITY STATEMENT

Approved for public release; distribution is unlimited.

12b. DISTRIBUTION CODE

13. ABSTRACT (Maximum 200 words)

Frequent dredging requirements and scouring at the foundation of Ocean City Inlet's south jetty resulted in a study to determine the source of the shoaling and scouring. The study concluded that sand was being transported northward along Assateague Island, through and over the south jetty, and deposited inside the inlet. The sand was then transported north by ebb currents where it encroached on the Federal navigation channel. A rehabilitation program was initiated to create a littoral barrier to eliminate the shoaling problem and to repair the scour hold. Three headland breakwaters were constructed to stabilize Northern Assateague Island. The site was selected as part of the Monitoring Completed Coastal Projects (MCCP) Program to determine how well the rehabilitation project accomplished its design purpose. The monitoring program extended from October 1986 through January 1989. Activities included beach and offshore surveys, aerial and ground photography of the inlet and adjacent shorelines, inlet hydraulic surveys, nondirectional wave gauging, and side scan sonar surveys of the scour area. The monitoring program indicated that the south jetty performed as expected. The rehabilitated jetty eliminated the source of material to the shoal area while the headland breakwaters stabilized North Assateague Island. No further erosion within the scour area was observed.

14. SUBJECT TERMS

Headland breakwaters

Inlet shoaling

Jetty rehabilitation

Ocean City Inlet

Profile response

Sand tightening

Scour

Shoreline stabilization
15. NUMBER OF PAGES

122

16. PRICE CODE

\section{SECURITY CLASSIFICATION 18. SECURIY CLASSIFICATION 19 . SECURITY CLASSIFICATION 20. LIMITATION OF ABSTRACT OF REPORT OF THIS PAGE} UNCLASSIFIED UNCLASSIFIED 

Destroy this report when no longer needed. Do not return it to the originator. 

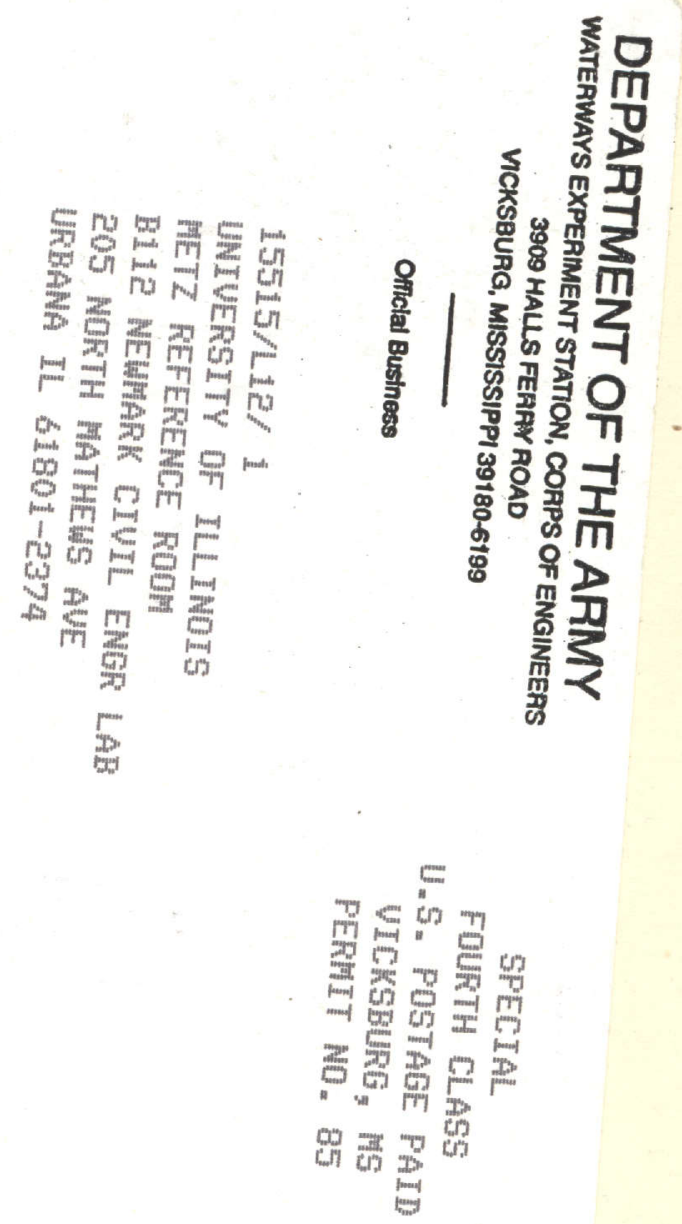